\title{
Essays on corporate governance
}

Citation for published version (APA):

Rebers, E. H. (1998). Essays on corporate governance. [Doctoral Thesis, Maastricht University]. Universiteit Maastricht. https://doi.org/10.26481/dis.19981204er

Document status and date:

Published: 01/01/1998

DOI:

10.26481/dis.19981204er

Document Version:

Publisher's PDF, also known as Version of record

\section{Please check the document version of this publication:}

- A submitted manuscript is the version of the article upon submission and before peer-review. There can be important differences between the submitted version and the official published version of record.

People interested in the research are advised to contact the author for the final version of the publication, or visit the DOI to the publisher's website.

- The final author version and the galley proof are versions of the publication after peer review.

- The final published version features the final layout of the paper including the volume, issue and page numbers.

Link to publication

\footnotetext{
General rights rights.

- You may freely distribute the URL identifying the publication in the public portal. please follow below link for the End User Agreement:

www.umlib.nl/taverne-license

Take down policy

If you believe that this document breaches copyright please contact us at:

repository@maastrichtuniversity.nl

providing details and we will investigate your claim.
}

Copyright and moral rights for the publications made accessible in the public portal are retained by the authors and/or other copyright owners and it is a condition of accessing publications that users recognise and abide by the legal requirements associated with these

- Users may download and print one copy of any publication from the public portal for the purpose of private study or research.

- You may not further distribute the material or use it for any profit-making activity or commercial gain

If the publication is distributed under the terms of Article $25 \mathrm{fa}$ of the Dutch Copyright Act, indicated by the "Taverne" license above, 
Essays on Corporate Governance 
ISBN: $90-9011904-3$ 


\title{
Essays on Corporate Governance
}

\author{
PROEFSCHRIFT
}

Ter verkrijging van de graad van doctor an de Universiteit Maastricht, op gezag van de Rector Magnificus, Prof. dr. A.C. Nienwemhnijzen Kruseman, volgens het besluit van het College van Decanen, in het openbaar te verdedigen op vijolag 4 december 1998 om 16.00 uur

door

Eugene Henri Rebers 


\section{Promotores:}

Prof. dr. H.J.M. Peters

Prof. dr. C.C.P. Wolff

\section{Co-promotor:}

Dr. RM.W.J. Beetsma

\section{Beoordelingscommissie:}

Prof. dr. F.C. Palm (voozzitter)

Prof. dr. P.W. Moerland (Katholicke Universiteit Brabant)

Prof. dr. P.C. Schotman 


\section{Preface}

Most of the chapters in this thesis have already appeared as articles. A Dutch version of Chapter 2 appeared as Rebers (1997). Chapter 3 is a revised version of Rebers et at (1997). Chapter 4 is a revised version of Rebers (1996). Chapter 5 is joint work with Enrico Pennings.

\section{Acknowledgments}

In writing my thesis, I have greatly benefitted from the support of many people. First of all I would like to thank my thesis supervisors, Hans Peters, Christian Wolff, and Roel Beetsma, for their time and trust. Hans has encouraged this project from start to finish. I found his door always open, and our discussions were both fruitful and amusing. Christian has initiated the project. I have greatly benefitted from the inexhaustible energy and professionalism of Roel.

Of course, I would also like to thank my colleagues in the Finance Department, LIFE, and from the Department of Quantitative Economics, with whom I have shared many useful discussions and experiences. The Midi-Pyrénées School of Economics provided me with a nice research environment to finish this thesis. Financial support from the ESR (grant no. 510-31-103) is gratefully acknowledged.

Finally, I would like to thank my family and friends for their support. 



\section{Contents}

Preface v v

Acknowledgements v v

1. Introduction 1 1.

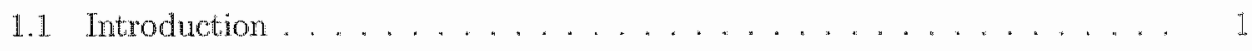

1.2 The Stakeholders of the Modern Corporation . . . . . . . . . . . . 2

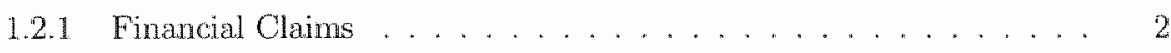

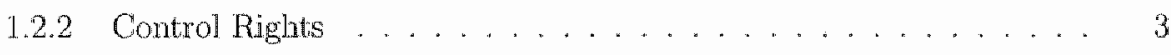

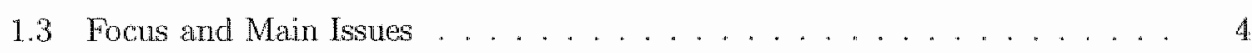

1.3.1 The Board of Directors . . . . . . . . . . . . . . . . 4

1.3 .2 Asymmetric Information . . . . . . . . . . . . 5

1.3 .3 Unverifiable Variables .................. . . . . . . .

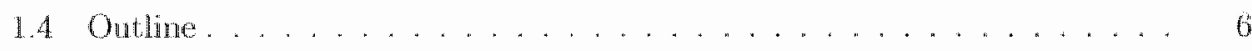

2 Corporate Governance in the Netherlands; the "Structuurregirne" in an Internationall Perspective 9

2.1 Introduction . . . . . . . . . . . . . . . . . . . . . . . . .

2.2 The Modern Corporation....................... 12

2.3 The Structunregime ..................... 14

2.3 .1 Independent and Competent Board of Directors . . . . . . . . 16

2.3.2 Balanced Protection of the Interests of All the Stakcholders . . . 1.7

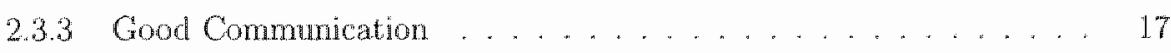

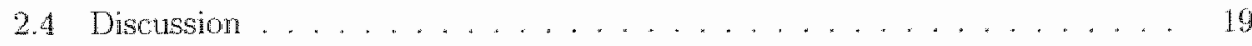


2.4.1 Trude-off between Liquidity and Effective Control . . . . . . . . 19

2.4 .2 Accountability of the Board of Directors . . . . . . . . . . . . 20

2.4 .3 The Market for Corporate Control . . . . . . . . . . . . 21

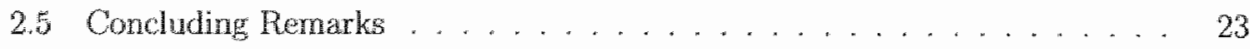

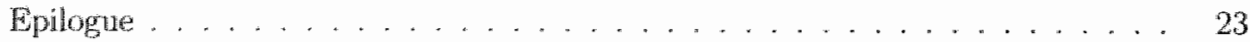

3 When to Fire Bad managers: The Role of Collusion Between Manage$\begin{array}{ll}\text { ment and Board of Directors } & 29\end{array}$

3.1 Introduction . . . . . . . . . . . . . . . . . . . 29

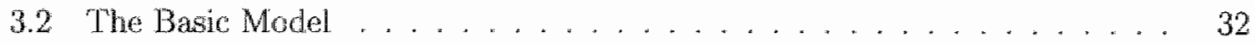

3.3 The First Best . . . . . . . . . . . . . . . . . . . . . 34

3.4 No Director . . . . . . . . . . . . . . . . . . 36

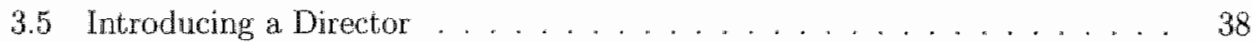

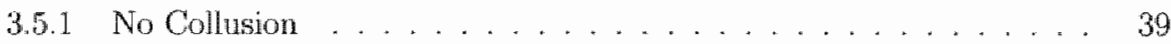

3.5 .2 Collusion ................................ 41

3.6 When is it Optimal to Allow fon Collusion? . . . . . . . . . . . 45

3.7 Concluding Remarks . . . . . . . . . . . . . . . . . . 46

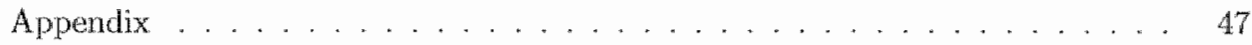

4 Incentive Signalling and Bankruptcy 53

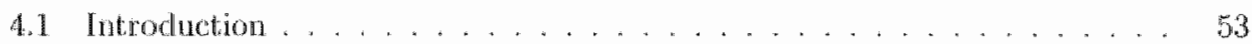

4.2 The Basic Model . . . . . . . . . . . . . . . . . . . 56

4.3 Perfect Bayesian Equilibria . . . . . . . . . . . . . . . . . 60

4.3 .1 Separating Equilibrium . . . . . . . . . . . . 62

4.32 Pooling Equilibrium ..................... 64

4.4 The Intuitive Criterion . . . . . . . . . . . . . . . 64

4.5 Conchling Remarks . . . . . . . . . . . . . . . . . 67

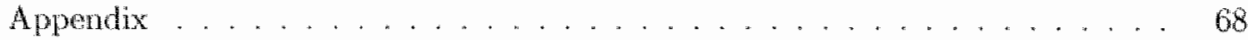

5 The Option to Fire A Manager $\quad 73$

5.1 Lntroduction . . . . . . . . . . . . . . . . . 73

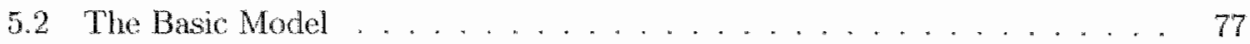


5.3 Preliminary Results . . . . . . . . . . . . . . . . 78

5.3.1 Option Value, Critical Value, and Expected Time of Firing . . . . . 79

5.3 .2 Expected Firing Costs . . . . . . . . . . . . . . . 80

5.4 The First Best . . . . . . . . . . . . . . . . . 81

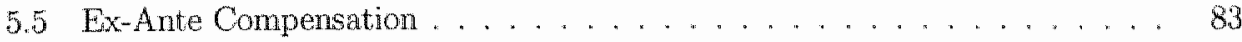

5.5 .1 Expected Firing Costs ..................... 84

5.5 .2 The Optimal Ex-Ante Contract .................. 85

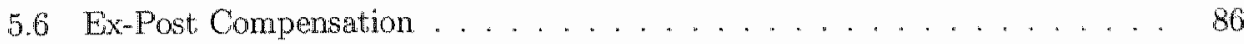

5.6 .1 Expected Firing Costs . . . . . . . . . . . . . 86

5.6 .2 The Optimal Ex-Post Contract .............. 89

5.7 Comparing Ex Ante and Ex-Post Compensation . . . . . . . . . . 90

5.8 The Second Best . . . . . . . . . . . . . . . . . 92

5.9 Concluding Remarks ....................... 95

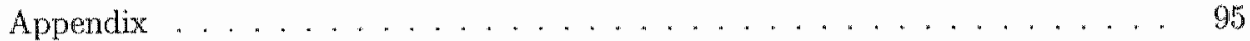

$\begin{array}{ll}\text { Bibliography } & 97\end{array}$

$\begin{array}{ll}\text { Nederlandse Samenvatting } & 105\end{array}$

$\begin{array}{ll}\text { Index } & 111\end{array}$

$\begin{array}{ll}\text { Curriculum Vitae } & \mathbf{1 1 3}\end{array}$ 



\section{Chapter 1}

\section{Introduction}

\subsection{Introduction}

This thesis bundles four essays (Chapters 2 to 5) on corporate governance, i.e, the governance of the modern corporation. ${ }^{1}$ 'There are two important reasons why this subject has received (and still receives) a lot of attention, both in the scientific literature as well as in the popular press. ${ }^{2}$ The first reason is that the modern corporation is of great economic importance to society. Although the number of modern corporations is relatively small compared to the number of small and medium-sized firms, their mere size makes their contribution to economic output considerable. The second reason is that the modern corporation has many stakeholders, which implies that the distribution of financial claims and control rights is non-trivial (see Section 1.2).

The number of issues that have been studied in relation to corporate governance is overwhelming. ${ }^{3}$ A certain focus is therefore needed. Section 1.3 illustrates the choices that we have made, i.e, the scope of this thesis. Moreover, it provides a short overview of the main issues that can be found in one of the next four chapters. A chapter-by.chapter overview of the remainder of the thesis is given in Section 1.4 .

\footnotetext{
The modern corporation can be roughly described as a large and listed compary. We will say more on the modern corporation in Section 2.2 .

${ }^{2}$ Unfortunately, it is mainly negative publicity that reaches the popular press, like reporting about firms in financial distress, or excessive sewerance payments.

${ }^{3}$ See Shleifer and Vishury (1997) for a recent survey.
} 


\subsection{The Stakeholders of the Modern Corporation}

Without the intartion of being complete, we have drawn Figure 1-1 to give an impression of the great variety of stakeholders, both inside and outside the modern corporation.

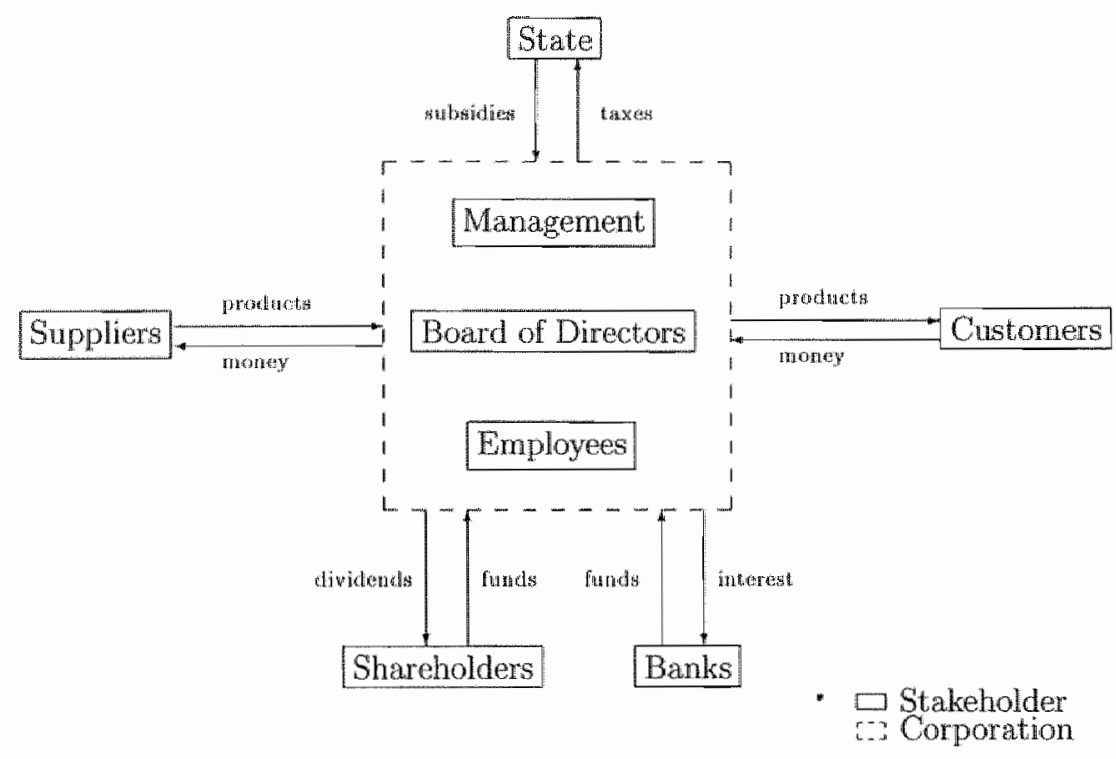

Figure 1-1: The stakeholders of the modern corporation.

Economists have studied two important issues resulting from the interaction between these different stakeholders (economic agents). The first is the distribution of financial claims (Section 1.2.1), the second the distribution of control rights (Section 1.2.2).

\subsubsection{Financial Claims}

In some sense, alli the stakelolders in Figure 1-1 are financial clsimholders to the corporation. Inside the corporation, the management, the Board of Directors, and the employees all receive a salary from the corporation. Salaries can be a fixed amount, but also some form of profit-sharing. The suppliers need to be paid for the products they deliver, either directly, or on account. Customers can have an option to get their money back if the products do not satisfy their expectations, or they may need the corporation for future 
services, like repairs or spare parts. The State has a clam on the profits in the form of corporate taxes. Fixed amounts need to be paid to the banks, which inchude interest. Last but not least, the shareholders have the right to all the profits of the corporation that remain after all the other claims have been paid. They will eventually be paid out in the form of dividends. Since all the stakeholders have genuine claims on the corporation, the question arises as to who should have sorne influence on the policy of the corporation. This brings us to the issue of control rights.

\subsubsection{Control Rights}

It is clear that a system with so many stakeholders cannot exist. for a long time if one stakeholder has absolute control ower the corporation, so that a more sophisticated system of checks and balances is needed. In fact, there are many regulations, institutions, and conventions that guarantee at least a minimum protection of the interests of the stakeholders. To mention a few, there are accounting regulations to ensure that taxes can be properly determined, unions to protect the most fundamental rights of employees, and covenants in debt contracts to ensure the repayment of the loans. This, however, holds for almost any firm, and is therefore not particular to the modern corporation.

The separate treatment of the modern corporation has become common use after the pathbreaking book of Berle and Means (1932). One of the most distinguishing features of the modem corporation is the separation of ownership and control. This is illustrated in Figure 1-1 by the fact that management and shareholders are two separate entities. In this respect it is important to note that shareholders are residual claimants, which implies that their interests are least protected. Therefore, their payoff is highly dependent on top-level corporate decisions. It is mainly (top-)management, however, that actually takes these decisions. To be sure, the interests of management and shareholders are not necessarily the same. Therefore, the distribution of the (residual) control rights concerning important. corporate decisions is an important issue in corporate governance, which we address in the next section. 


\subsection{Focus and Main Issues}

In this thesis, we focus on a subset of all the stakeholders of the modern corporation as dexcribed in Figure $1-1$. This subset is depicted in Fgure $1-2$. The interaction of these three

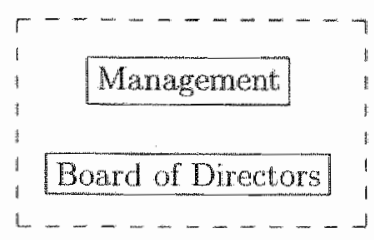
Shareholders Stakeholder
C.: Corporation

Figure 1-2: The main stakeholders of the moden corporation that are studied in this thesis.

stakeholders, which is often formalized in a contract, already gives rise to an important number of issues that have been studied in the literature. In the following three subsections, we illustrate the main issues that can be found in this thesis.

\subsubsection{The Board of Directors}

In most compotations, the Board of Directors has a pivotal role in monitoring the actions of management. This raises two impontant questions. Firstly, wh whose intercsts should the Bowd of Directons perform its monitoring task? Two groups with opposing views can be distinguished. The firgt group argues that mainy the interests of the shareholders (the "owners") should be protected (shareholder apitalism). The second group argues that shareholders are just one of the interest groups of the corporation and, hence, that the interests of all the stakeholders should be protected (stakeholder capitalism). This ongoing debate will be further discussed in Chapten 2.

The other impontant question is how the Board of Directons should perform its monitoring task. The clean advantage of having a small Board of Directors which is close to management is that they will be better able to obtain useful information than a dispersed group of shareholders. However, it is not obvious that this infomation will be put to good 
use. The issue of possible collusion between management and Board of Directors is studied in Chapter 3.

\subsubsection{Asymmetric Information}

The fact that management handles the day-to-day business of the corporation implies that it will have an informational advantage over the shareholders. This has serious consequences if the shareholders and the (management of the) firm decide to do business or,

more formally, to enter into a contract. Two potential problems that result from this information asymmetry have been extensively studied in the literature. A first problem arises for example in the context of a labor contract between shareholders and management. The presence of asymmetric information implies that shareholders should take into account the possibility that management, ofter the contract has been signed, can take actions which are unobservable by the shareholders. This phenomenon is known as moral hazard.

A second problem arises when shareholders, before they sign the contract, do not know the type of the firm (or manager) that they are dealing with. This phenomenon is known as adverse selection. A possible solution is that managernent signals its type to the shareholders, an issue that is taken up in Chapter 4.

\subsubsection{Unverifiable Variables}

Even if there is no asymmetric information, signing a contract may be problematic. If a contract specifies that some action be taken contingent on the realization of some variable, then it is not sufficient that the parties can observe this variable (symmetric information) It is also necessary that the specified action can be enforced by a court of law. This will not be the case in the case of unverifiable variables. For exarnple, a juadge may lack the skills to underpin a judgement on the realization of the variable, or it is (infinitely) expensive to gather evidence on this variable. An important problem with unverifiable variables is that no party can commet itself to an action based on its realization. This issue is further studied in Chapter 5. 


\subsection{Outline}

In this section we systematically introduce and describe the main results of the next four chapters.

Chapter 2 puts the Dutch system of corporate governance, and especially one of its most important features, the 'Structurregime', in an international perspective. In this chapter, a clear distinction is made between shareholder capitalism and stakeholder capitalism, and it is shown that the Structuurregime belongs to the latter system of corporate governance. We argue that the relatively autonomous position and wide powers of the Board of Directors under the Structuurregime has two important (and related) advantages. Firstly, it enhances the independence and competence of the directors, because they can be purely chosen on the basis of their skills, and not of their interests. This, in tum, guarantees a balanced protection of the interests of all the stakeholders. Secondly, it supports the liquidity of the stock market, because there is less need for concentrated shareholdings if the Board of Directors performs a large part of the monitoring function. Therefore, it is our opinion that the Structuurregime should not disappear. However, in order to enhance the accountability of the board, two obvious (and related) improvements could be implemented. Firstly, the report by the Board of Directors in the annual report should become much more detailed. This is necessary if shareholders want to form a serious opinion about the directors. Secondly, if shareholders are better informed, they should have more opportunities to dismiss a failing director.

A strong position of the Board of Directors is often criticized for fear of collusion between the Board of Directors and management, at the expense of the shareholders. In Chapter 3 we develop a model which shows that such collusion may be in the interest of the shareholders. In the model, w shareholden delegates the decision to fire a manager or not to a director. The manager faces stochastic firing costs and, hence, needs to be compensated for those costs. We study the optimal incentive scheme for the director, allowing for the possibility that the manager bribes the director in order to change his firing intentions. 'The problem with a non-colluding director is that he does not intemalize the firing costs of the manager. In other words, managers will be fired relatively often, and will therefore require a high compensation for the expected firing costs. We show that 
allowing for collusion can be beneficial for the shareholder, becuse it avoids the need to (ex ante) compensate the manager for very high realizations of his fring costs (these are precisely the cases in which collusion occurs). In the Anglom Saxom countries, the position of directors is weaker, and they can be more easily fred by the shareholders. Although this may prevent collusion, it may also explain why directors require a higher compensation.

Chapter 4 takes up the issue of adverse selection. An example of adverse selection arises when managers have inside information about the true value of their firm (say, "good" or "bad") which investors do mot have. If investors do not get additional information, the value of the firm as inferred by the market will be a weighted awerage of the values of all the firms. In other words, if they buy a (share of the) firm, they incur the risk of investing in (adversely selecting) a bad one, i.e., one of low value. Ross (1977) developed a managerial incentive schedule to induce managers to signal the true value of their firm. We formalize Ross's model into a signalling game, simnltaneously making the personal penalty that managers incur dependent on the bankruptcy costs, as follows. Managers are compensated in proportion to the value of the firm, and signal the true value of their firm by means of its debt level. By raising the debt level, managers face a trade-off between a higher value of the firm as perceived by the market, and a lower value of the firm as result of the increased risk of going bankrupt. We determine the exact conditions under which Ross's unique cornpetitive equllibrium can survive. In this equilibrium, managers of good fims are recognized as such by the market, becanse they will choose a debt level which is too expensive for managers of bad firms to imitate (because they have higher expected bankruptcy costs). The adverse selection problem, then, is resolved.

Finally, Chapter 5 develops a model in which a shareholder has the option to fire a. manager at any moment in time. The manager, again, incurs stochastic personal firitig costs when he is fred and, hence, needs to be compensated for these costs. This can either be achieved by raising the salary of the manager above his reservation wage in each period that he is still employed, or by granting the manager a severance payment (golden handshake) at the moment he is fired. The optimal compensation scheme and its relation to the nature of the firing costs is studied. We show that with the system of a higher salary, the shareholder has the incentive to fire the incumbent manager relatively often, resulting 
in high expected firing costs. Since the manager will anticipate this, he will require of correspondingly high compensation. The problem is that, once the higher salary is fixed, the sharebolder faces no additionall costs at the moment of firing the manager, ie., the ex post marginal cost of firing is zero. This problem is relieved with the system of a severance payment, because this system implies an additional cost for the shareholder at the moment of firing. Therefore, from the point of view of the shareholder, the severance payment is an efficient means to credibly commit not to fire the manager too early. The negative publicity by which the high severance payment is often surrounded should therefore be qualified. 


\section{Chapter 2}

\section{Corporate Governance in the}

\section{Netherlands; the 'Structuurregime'}

\section{in an International Perspective}

\subsection{Introduction}

Corporate governance is a highly multidlisciplinary topic. Not only do we find contributions to the scientific literature on economics, politics, and law, the popular press as well is highly interested in the governance of the corporation. That financial economists have a very pronounced voice in this debate stems from the fact that many issues in corporate governance directly concem the shareholders, or more generally all the claimholders of the firm.

Each country has developed its own system of corporate governance, including all the laws and conventions that surround the governance of the modern corporation. Yet it is useful, and common practice, to make a distinction between two main systems of corporate governance. The first is the Anglo-Saxon system of corporate governance. Here, the corporation is seen as an instrument in the hands of the shareholders, and these shareholders are supposed to have a key position in the governance of the corporation. This system is prevalent in the United States and the United Kingdom.

The second system is the Continental-European system of corporate governance. Here, 
a more institutconat view of the corporation prevalls, where different interests and interest groups come together. The governance of the corporation is no longer directed by, and solely in the interest of the shareholders. "The emphasis is more on the whole body of laws and conventions that takes account of all the interests of all the stakeholders in the corporation." Every country has its own specific implementation and features. Well known examples are the strong position of German banks due to their large voting power (Dew potstimmrecht'), and the large number of cross-holdings of French corporations ("noyanx. durs'). Important features of the Dutch system of corporate governance are the great number of legal barriers encountered when taking over the control of a corporation, and the so-called 'Structuurregime', which determines the division of power between the employees, the shareholders, and the Board of Directors. The Structururegime will be discussed in some detail in Section 2.3 .

An important issue in the corporate governance debate is the question of low to discipline management. Again we make a distinction between the two main systems. The Anglo-Saxon system relies to a great extent on the functioning of the take-over market, which confirms the key position of the shareholders in this system. In contrast, the Continental-European system telies more on internal control mechanisms, in which the board of directors has an important monitoring role. In this light, the Anglo-Saxon system is often referred to as manket oriented, and the Continental-European system as network wriented. ${ }^{2}$

In the past few years there has been an increasingly strong call for more influence of sharcholders in the Continental-European system. In the Netherlands, this call is especially pronounced by the association of shareholders, the so-called Vereniging van Effectenbezitters' (VEB). Especially the strong position of the Board of Directors in the Structuurregime is heavily criticized. The call for mone shareholder infuence is gradually accepted, and we see a certain shift towards the Anglo-Saxon system. However, the Anglo-Saxon system itsell is also being criticized, especially after some excrescences of the restructurings in the

\footnotetext{
${ }^{1}$ Note that the Anglo-Snxon system and the Continental-European system are often described as sharehoider capitalism and stakeholder capitalism, respectively.

${ }^{2}$ A part from its geographic location, one could also classify Japan, with its network-oriented system known as Keiretsu, atis Continental-European.
} 
80s. It is often argued that the shareholder influence in this system may be too strong: Moreover, there is an ongoing discussion on the role and position of the Board of Directors in the Anglo-Saxon system. Since both the Anglo-Saxon and the Continental-European system are in a process of change, it is useful to consider them simultaneously when we take a closer look at some aspects of corporate governance.

In this chapter we focus on the functioning of the Structuurregime, especially with respect to the disciplining of management. The Structuurregime is one of the most important elements of the Dutch system of corporate governance. It contains some features which are clearly distinct from other systems of corporate governance (the strong position of the Board of Directors being the most distinguishing among them). This makes a comparison to other systems of corporate governance more interesting, and offers the opportunity to evaluate the functioning of both the Dutch system as well as the other systems. Since the Dutch system belongs to the Continental-European system of corporate governance, we compare most of its features with the Anglo-Saxon system of corporate governance.

The remainder of this chapter is as follows. In Section 2.2, we describe the main characteristics of the modern corporation which are useful to understand the actual discussion on corporate governance. A description of the main features of the Structuurregime follows in Section 2.3. We argue that the wide powers that it allots to the Board of Directors promotes an independent and competent Board of Directors (Section 2.3.11), a balanced protection of interests of all the stakeholders (Section 2.3.2), and good communication between the Board of Directors and management (Section 2.3.3). Section 2.4 contains a discussion of the merits of the Structuurregime. We focus on three aspects: the trade-off between effective control and liquidity (Section 2.4.1), the accountability of the Board of Directors (Section 2.4.2), and the market for corporate control (Section 2.4.3). Section 2.5 concludes. At the end of the chapter we have added an Epilogne, in order to discuss the main extracts of the report of the Dutch Committee on Corporate Governance ('Commissie Peters') which relate to the discussion in this chapter. 


\subsection{The Modern Corporation}

It is impossible to imagine economic life today without the modern corporation. Technological innowations have increased the scope of the firm, which has led to a larger average size of the firm. This process of increasing scale is aptly summarized by three well-documented merger waves." A fundamental characteristic of the modem corporation is the separation of ownership and control, i.e., managers and shareholders constitute separate entities of the firm. This contrasts sharply with (small) owner-manager firms, where an entrepreneur, or sometimes whole fomilies, contribute the necessary funds themselves.

The separation of ownership and control entails an important agency relation between the managers and the financial ctaimholders of the corporation. This relation involves many potential problems, which are illustrated by an impressive body of literature on the subject, starting with the seminal work of Berle and Means (1932). According to Jensen and Meckling (1976), "the most important conflict arises from the fact that as the manager's ownership clain falls, his incentive to devote significant effort to creative activities such as searching out new ventures falls' [p.313].

De rasson d'etre of the modem corporation can be concisely described by a need of sufficient funds, diversification considerations, and specialization of management. These three elements imply that the suppliers of funds and the entrepreneur need one another. The first do not have the time or skills to carry out the management of the firm themselves, while the latter do not have sufficient funds, or are unwilling to put all their money in the venture. The mere oxistence of the modern corporation seems to imply that its advantages more than outweigh its intrinsic problems. However, this otherwise interesting issue is beyond the scope of this chapter. We simply assume the appropriateness of this organiwational structure in certain markets and in certain times."

If we compare the position of the small shareholder in the modern corporation to that of an owner-manager, then it is immediately clear that the former has lost direct control

\footnotetext{
'The first nerger wave is often referred to as 'The Great Merger Movenent' (1895-1905), the second as "The Visible Hand' (1920-1929), and the third as "Big is Beautiful" (1950-1970) [e.g., Wildenberg (1990)].

"One of the challenges of "transaction cost econonics" is to describe the factors that determine the optimal size and organization of firms and markets. This type of research starts with Coase (1937), and has received new impetus from Willianson (1985).
} 
over his stake in the firm. Nevertheless, his shares offer good opportunities to build a well-diversified portfolio that can be readily sold at any moment in time without too much cost. Berle and Means (1932) already indicated the trade-off between effective control and liquidity. We will return to this issue in some detail in the discussion (Section 2.4.1). For the moment it is important to note that the modern corporation, in contrast to the ownermanager firm, needs some additional control mechanisms. This is not only because its mere size makes the modern corporation a complex organization of high social value with many stakeholders, but also because of the intrinsic agency relation between the managers and the financial claimholders. ${ }^{5}$ This is exactly the topic of corporate govenance.

According to Boot (1994), corporate governance relates to the mode and extent to which the different stakeholders can exercise some influence on the decision processes of the modern corporation. This includes the way in which management gives accountability of its performance.

Traditionally, the discretionary power of management is assumed to be restricted in at least three ways [e.g. Moerland (1989)]. Firstly, competition in the product markets will impose some limits on the possible behavior of management. Secondly, the internal and external labor markets for managers will have some disciplining effects on management, since their market walue is (partly) determined on the basis of their past performance. Finally, the market for corporate control can function as a last resort to correct poor performance of managers.

The 80s have witnessed a dramatic increase in the activity on the market for corporate control. Almost everybody agreess that some form of restructuring was necessary as a reaction to the unbridled conglomerate merger waves of the 60s. Wildenberg (1990) cheers the return of the owner-manager. ${ }^{7}$ Jensen (1989) even professes the eclipse of the modern corporation. More recently, however, some doubts have arisen about the efficiency of the

\footnotetext{
"See also Fama and Jensen (1983a) for their definition of complex organizations.

"If we define the market for corporate control as 'a masket in which alkernative managerial teams compete for the rights to manage corporate resoures' [alensen and Ruback (1983)], then this market will have many similarities with the labor market for managers.

${ }^{7}$ Although Wildenberg (1990) welconues the regurrection of the owner-manager, he describos the 80 . as a traumatic experience for the United States. According to the atuhor, it is not so nuch the question when Europe and Japan will convert to the classic economy of Adam Snith, but rather: when the United States and the United Kingdom will start to protect their corporations agaings the sale to foreigners and corporate raiders!
} 
market for corporate control. Prahalad (1994) claims that the activity of the "corporate control" market during the 80s was not wn indication of the success of the US corporate governance system, but rather a clear sign of its falure. The stockholder activism of the '80s was a response of last resont, and it therefore functioned as a very blunt instrument of corporate reform."

The market for corporate control can be characterized as an extemal control mechanism, which has been particularly prevalent in the Anglo-Saxon world. The changing view on its efficiency, however, has gradually shifted attention to intemal control mechanisms. In most corporations, the Board of Directors plays an important role in this. Therefore, much attention is directed at questions regarding the task and composition of this board. Morck at al. (1989), and Byrd and Hickman (1992) mention an increased interest in these matters, as a consequence of a failing market for corporate control.

It is well-known that the Dutch Structurregime allots a very specific task to the Board of Directors. Moreover, in order to perform this task, it assigns many powers to the Board of Directors. The features of the Structuurregime will be described in some detail in the next section, followed by a discussion of its pros and cons in Section 2.4.

\subsection{The Structuurregime}

In the 60s, a number of committees were established in the Netherlands, with the assignrnent: to investignte the functioning of the corporate system. This resulted in a number of new haws, two of which are of special importance to us. The first law concerned the Employees Council. Besides non-negligible influence through their unions, employees now received genume voice within the corporation. The Employees Council can demand for information on almost any issue, and has advisory rights in all important corporate decisions. All this has implied an institutionalization of the participation of the employees, and can be seen as an implementation of what has been previously referred to as the institutional view on the corporation.

The second law concerned the implementation of the Structuurregime in 1971. This law was in line with the law on the Employees Council. In fact, the law did nothing more than institutionalizing the weakened position of the shareholders. This was effectuated by 
transferring important powers from the general meeting of shareholdexs to the Board of Directors. The most important of these are:

1. The appointment and dismissal of management,

2. The composition of the annuall report,

3. The approval of important corporate decisions, such as:

(a) mergers and acquisitions,

(b) changes of the corporate charter,

(c) important investments.

The final piece of the Structuurregime was to have the Board of Directors be appointed by a system of so-called 'controlled co-optation." This implies that the board itself appoints its own members. The co-optation is controlled, because the general meeting of shareholders and the Employees Council both have an equal, albeit a marginal influence on these appointments by means of an advisory right and a proviso right of veto. ${ }^{8}$

The Structuurregime is often described as 'the miracle from The Hague", ' and its advocates claim it to be a unique solution to the everlasting conflict between labor and capital. As already noted, the Structuurregime is in line with the law on the Employees Council, which is for example illustrated by the fact that the general meeting of shareholders and the Employees Council both have an equal influence on the appointment of directors. This is a second clemonstration of the fact that the institutional view on the corporation prevails in the Netherlands. ${ }^{10}$

More details are not important for this chapter. The most important features are that the board appoints itself, and that it controls almost every important event in the corporation. Before we continue with our discussion of the strong and weak aspects of

\footnotetext{
"The advice is not binding. The right of veto is proviso in the sense that it can be coverruled by a judge

"The govermment of the Netherlands has its seat in The liague.

11) Tn this respect it is interesting to evoke the Dutch 'poldermodel', which has recently received some attention in the (international) press. One of its main features is that the 'soriab partmers' (the stakeholuders of society) ofter consult each other in social affairs. The institutional (network oriented) view on the corporation is a clear exponent of this 'corporative econony."
} 
the Structuurregime in comparison with the Anglo-Saxon system (Section 2.4), we will fret spend a few more paragraphs on the potential advantages of having a strong and independent Board of Directors. According to Rinnooy Kan (1994), there are three crucial conditions that need to be satisfied in order to have a well-functioning Board of Directors:

1. Independent and competent Board of Directors,

2. A balanced protection of the interests of all the stakeholders,

3. Good communication between management and Board of Directors

In the following three subsections we argue that the Structuuregime satisfies these conditions satisfactorily.

\subsubsection{Independent and Competent Board of Directors}

The United States have a 'single-tier' system, in the sense that management (the executives) are chosen from and by the Board of Directors. Moreover, it is common practice that the Chief Executive Officer (CEO) atso presides the Board of Directors. "Although this may facilitate the communication between management and Board of Directors, Boot (1994) argues that it may be one of the most important reasons of why the monitoring of management seems to fail in the United States. In this respect, he cites Grundfest (1990): 'Investors' ability to monitor corporate performance and to control the assets that they ultimately own has been subordinated to the interests of other constituencies, most notably comporallio mangoment."

The Netherlands have a "two-tier" system, ir which the management and the Board of Directors are two clearly separated entities of the corporation. In this respect, the Duth director is more independent than his American counterpart. The Dutch director bears much resemblance with the "outside' director of Byrd and Hickman (1992), whose "|... objectivity and independence is especially important if shareholders interests are to be represented, because only they can ask the hard questions that even conscientious managers may oxerlook."

\footnotetext{
"For a good overview of the American situation, see Charkham (1994).
} 
The system of co-optation implies that directors are not chosen by or from any interest. group whatsoever. This serves two important goals. Firstly, it guarantees that the directors are independent, not only from management, but also from the direct wishes of the interest groups. This encourages a balanced protection of interest.s. ${ }^{12}$ Secondly, it enlarges the pool of potential directors to choose from. Hence, they can be closen on the basis of their skills, and not of their interests. This lays the foundation for effective and confidential communication with management.

The remark that directors need to be competent seems rather superfluous. However, it has to be understood in the light of the specialization of management as discussed in Section 2.2. In order to act both as a sounding board for and a monitor of management, it seems obvious that at least some form of specialization is needed to offer some resistance wis-à-vis a well-informed and highly specialized management. This is another illustration. of the importance to be able to select directors on the basis of their skills, and not on the basis of whose interests they serve.

\subsubsection{Balanced Protection of the Interests of All the Stakeholders}

This is very typical for the institutional view on the corporation. It recognizes that the various stakeholders have different interests, all of which can vary over time in importance. An independent Board of Directors is in the right position to balance all these different interests. To be sure, at a certain moment in time, when its interests are at stake, some interest group could wish to have more influence on corporate decisions. However, it is very well conceivable that, from an ex ante point of view, each interest group is better off by delegating the monitoring role to an independent, Board of Directors.

\subsubsection{Good Communication}

The modern corporation is almost by definition a very complex organization. Therefore, in order to perform the monitoring task in a satisfactory way, adequate information is

\footnotetext{
12 Rinnow Kan (1994) notices that the German system is mesnerized by the fitty fifty split between emplayers ard employees, which implies that both have the right to an equal number of seats on the Board of Directors (Mitbestimmurg"). As a consequence, meeting are very formal, and discussions are oftentimes not properly completed.
} 
required. However, Moenland (1995) discerns three potential problems if management tries to difnse its information to its stakeholders in general:

1. To protect the firm's competitive position, full dissemination of information can be very harmful to the corporation and its stakeholders. Take the following example of a corporation that has just developed a potentially very profitable new technology. Management could explain al. I of the details of the new technology to its stakeholders, such that they can estimate more precisely the impact on the value of the firm. However, if (potential) competitors also receive this information, then the corporation will probably not be able to exploit the new technology to the full extent.

2. Management may find it hard to convince their stakeholders that their information is reliable. After all, if management knows that, their information will be used for monitoring purposes, they will have a natural tendency to depict the results in the most optimistic (maybe opportunistic) way. A vast amount of literature on signalling, more specifically referred to in Chapter 4 , supports this.

3. There is a genuine danger that some stakeholders will become better informed than others, which may result in insider trading. Since the corporation itself has some responsibility to prevent insider trading, some prudence is called for. ${ }^{13}$

Delegating the monitoring role from the stakeholders to the Board of Directors implies that a large part of the information flow from management will directly go to the Board of Directors. This will alleviate the three problems mentioned above, the main reason being that the Board of Directors is a relatively small group of specialized people, to whom it is easier to (confidentially) communicate information than to a highly dispersed group of stakeholders. For the same reason, directors can more easily be made responsible for nisuse of information.

\footnotetext{
"See Rivetkerk (1984) for a very prononnced wiew on this matter.
} 


\subsection{Discussion}

The Dutch legislator has been guided by the institutional vew on the corporation in designing the Structurregime. A central role is occupied by the Board of Directors, main duty is to monitor and advice the management of the corporation, in order for assure a balanced protection of interests of all the stakeholders of the conporation. To that end, as we have argued in the previous section, it is crucial that the Board of Directors be an independent entity, staffed with competent directors, who can confidentially communicate with management. We will now discuss the pros and cons of the Structuurregime in three different subsections.

\subsubsection{Trade-off between Liquidity and Effective Control}

Grundfest (1990), Roe (1990) and Bhide (1993) have shown that in the tradeoff between effective control and liquidity (see Section 2.2), the financial policy of the United States has clearly been to enhance the latter. There are numerous rules and regulations that: promote fragmented holdings of shares. Promoting liquidity also includes the protiection of small shareholders, such that they will not leave the market. Fon example, the United States have a long tradition of regulations to prevent insider trading.

Well functioning (liquid) capital stock markets are of great importance to ar economy. They provide an efficient way to build a diversifed portfolio. Modern portfolio theory would not exist without these markets. Entrepreneurs who have profitable possibilities to expand their business, could face considerable problems if the providers of the (risky) funds would lack these possibilities of diversification.

Another important advantage of liquid stock marlets is that they contribute to the situation in which every shareholder is better of if management maximizes the net present value of the future cash flows of the firm. In contrast, if investors can not be sure to be able to sell their shares at any monent in time without considerable costs, thon "I... it is rational for risk bearers to attribute lower current value to uncertain cash flows than is implied by capital market prices for the future resonnces" [Fama and Jonsen (1983b)]. "This, in turn, would result in a suboptimal investment policy of the corporation. In other words, liquid stock markets guarantee that different time and/or risk preferences of investors do 
not disturb the optimal (investrnent) policy of the corporation.

Hence, the choice that the United States have made in favor of liquidity definitely has some major advantages. However, it also makes clear why their market for corporate control has failed. After all, effective control by shareholders almost necessarily requires a high concentration of stockholdings. This is not only necessary to make effective control possible, but also to make it profitable. A shareholder who wishes to intervene in the corporate policy will have to make some (considerable) costs to obtain the necessary information. He will only do this if the expected return of doing this is sufficiently high, which will be the case only when his stake in the firm is also suficiently high. ${ }^{4}$

The United States are somehow stuck between two thoughts. On the one hand, they want to enhance the liquidity of the stock market by protecting small shareholders but, on the other, they rely on these small shareholders to function as good monitors! The Dutch system is more consistent im this respect. By transferring some powers from the shareholders to the Board of Directors, the latter can perform the monitoring function, without harming the liquidity of the stock market.

\subsubsection{Accountability of the Board of Directors}

Although an independent and competent Board of Directors is very important, it is beyond any doubt that this Boand of Directors needs to be monitored as well. Who monitors tho monitor? In the Structuuregime, both the general meeting of shareholders and the Employees Council already have sone influence on the co-optation by means of the advisory right, and the proviso right of veto. However, almost unanimous consensus exists on the font that a stronger accountability of the Board of Directors is needed. For example, inwoluntary dismissal of a director is only possible through the ruling of a judge. However, she will only allow the dismissal in situations of gross negligence.

As a first step, the report of the Board of Directors in the anmal report should become more comprehensive. For example, a critical assessment of the strategy and the risks involved in the corporation should be part of any annual report. Also, an argued explanation. of the extent of its compliance with the recommendations of the Committee on Corporate

\footnotetext{
". The tree-rider problem in take-ower situations is a good illustration of this [Grossman and Hart (1980)].
} 
Governance (1997) could be included. In that way, directors will have to clary their activities in a much more detailed way during the general meeting of shareholders, such that the latter are in a better position to form an opinion about the director. Moreover, benevolent: and competent shareholders will then be able to enter into debate with the directors. As a sequel to this, shareholders should get more possibilities to bring the dismissul of a director before the court. An objective lack of confidence in a director should be sufficiant ground for his dismissal. 15

To rely on a judge as a last resort has some serions drawbacks. According to Manne (1965): "courts are loath to second-guess business decisions or remove directors from office." However, if the report of the Board of Directors in the anmual report is put to good use, publicity can bear a helping hand. Directors, like managers, eventually have to yield in the case of continuous criticism. If not, the more detailed report of the Board of Directors can serve as a benchmark against which the board can be held responsible, which will increase the possibility of success of the dismissal procedure in court. Tf they let things come this far, directors must hawe al sure stance. Moreover, the negative publicity will have a downward effect on the stock price in a liquid stock market. This, in turn, will have a disciplining effect, because it increases the probability of a hostile take-over. Furthermore, the corporation will have to redeem its reputation on the stock market in order to be able to issule new stock.

\subsubsection{The Market for Corporate Control}

When discussing the issue of shareholder infuence on corporate decisions, we can make a distinction betweon the situation of a (hostile) take-over, and the situation of no take-over. According to De Hawe Winkelman (1994), former chaiman of the VEB and a clotr oppo-

\footnotetext{
151 deliberately only speak of more influence on the dismissal of a director, not of its appointment. The latter would be incompatible with the previously discussed concept of independent and conpetent directors.

"It should be noticed that the threat of dismissal of a malfunctioning director remains a last fesort to discipline directors. The same goes for the management of a corporation, and in practice we witness an increasing interest for incentive compensation as a disciplining device for management. In this light. it is strprising that the previously mentioned report of the Commitice on Corporate Governance (1997) claims that the renuneration of Supervisory Board members should not be deperdent on the results of the company.' See in this respect also Chapter 3 , where incentive compensation for directors is crncial from the point of vew of the shareholders.
} 
nent of the Structumregime in its current form, the Structumregime camnot be used as a defence mechanism against take-overs. Management will need convincing arguments, based on corporate interests, to prevent a take-over, but this will be difficult if the bidder is bona fide. If there is no take-over situation, De Haze Winkelman continues, the predominant position of the Board of Directors in the Structuurregime hampers an active contribution of the shareholders, which has a negative impact for all the stakeholders.

However, in our opinion it is better to reverse this argument. In the short run, the Structuurregime offers protection to the corporation against opportunistic behavion of shareholders, but in the long run, it will eventually have to bend for solid arguments. We will now put forward two arguments to support the hypothesis that the corporation needs some protection against too hasty take-over decisions. The first is based on differences between investors and managers, the second on information that is needed in tiake-over situations.

As a consequence of the separation of ownership and control, investors and managers have become specialized in their own tasks. An important difference between the two comes to light if we consider the way in which both constituencies are used to handle processes of change. Professional investors are used to almost instantaneously and frictionlessly adapting their portfolios in reaction to new information. In contrast, managers operate in relatively inefficient markets, where time is a relatively important decision variable in the process. This difference is nicely described by Donaldson (1994), who conchules: 'As a. result, professional investors typically lack the experience, expertise, and particularly the patience rieeded to manage a major corporate restructuring.' Hence, Donaldson indicates that some protection in the short run is needed. However, he also recognizes that in the long run, the take-over market should be able to function properly: "[...] The potential for external intervention by capital-market agents is needed as a last resort, the threat of which helps keep management focused on action necessary to preserve its cherished independence.'

The importance of adequate information in take-over situations has already been described by Manne (1965). In this light he argued that it would be a good thing if corporations themselves could also play an active role in this market. With this point of view, Manne took a stance against the very strict merger regulations of the day. However, it also 
indicated that he was afraid for premature take-over decisions: 'Managers of a competing firm, unlike free-wheeling individual participants in the market for corporate control, almost automatically know a great deal of the kind of information crucial to a takeover decision.

\subsection{Concluding Remarks}

From a corporate governance point of view, the most important characteristic of the Structuurregime is the very strong position of the Board of Directors. The extensive powers and the system of co-optation of this Board of Directors serve two important goals. Firstly, it increases and facilitates the possibilities to hire independent and competent directors, capable of performing their task of monitoring and advising a specialized management. Secondly, it guaranties a balanced protection of interests of all the stakeholders of the corporation. Moreover, the extra layer between shareholders and managers discourages opportunistic behavior of the former, which secures equal rights for all shareholders and, therefore, the liquidity of the stock market.

It is our opinion that the Structuurregime should not be abolished (as suggested for example by the VEB). However, it seems that two obvious improvements of the system should be enforced. First of all, the report of the Board of Directors in the sinmal report and in the general meeting of shareholders should become far more comprehensive. Secondly, more opportunities to dismiss a malfunctioning director should emerge. A combination of these two improvernents will lead to greater, and more transparent accountability of the Board of Directors, without compromising the advantages of the Structuurregime as previously discussed.

\section{Epilogue}

As a result of an agreement between the Association of Securities Issuing Companies and the Amsterdam Stock Exchange Association, a Committee on Corporate Governance 
(CCG) was established in the Netherlards in April $1996{ }^{17}$ "The purpose of the CGG was to document the existing system of corporate governance, and to propose improvements in this system which could be enforced without changing the existing law. The CCG has produced two reports. The first report was published in October 1996, and carried the sub title "The intiation of change and an invitation to debate." The invitation has readily been accepted, and the CCG has received a large number of reactions from institutions, organiwations, companies, and private persons. An important reaction came from the 'Vereniging van EffectenBexitters" (VEB), the Dutel Association of Stockholders. The CCG has extensively discussed all the reactions, and published their second and final report, incorporating some of the reactions, in June 1997.

The report of the CCG has certainly intensifted the public debate on corporate govemance. A full discussion of the report and the resulting debate is not possible in this epllogue, simply because the number of issues that are discussed in the report is too lange. However, we will discuss some of the issues of the report that bear relation to the main topic of this thesis, i.e, the relation between management, Board of Directors, and shareholders. We will first elaborate on the current need for a discussion about the system of corporate governance in the Netherlands. After that, we will return to two important. issues that have been put forward in this chapter, i.e., the independence and accountability of the Board of Directors. Finally, we will give a few comments on incentive compensation.

The Need for Discussion The position of the shareholder in the ContinentalEuropen system of corporate governance is weaker than in the Anglo-Saxon system. In this dupter, we have shown that this is also the case for the position of the Dutch shareholder under the Structumregime. Acoording to the $\mathrm{VEB}$, it is evident that the weak position of the Dutch shareholden has led to a low activity on the general meetings of shardolders." According to the VEB, shareholders, and especially institutional investors, will more actively use their voting rights if their position is strengthened.

However, it should be noted that the Structumregime was established to institutionalize the weakened position of the shareholcers. Because of low attendance rates and low quality

\footnotetext{
17 The Netherlands, this Committee is often referred to as the "Commissie Peters".
} 
of the discussions in the general meeting of shareholders, it was considered wise to transfer some powers from the general meeting of shareholders to the Board of Directors, in order to guarantee some continuty in the decision making. The CCG therefore follows another line of reasoning than the VEB: "The Commitee is confident that if the shareholders, especially the institutional inwestors and other major shareholders, are in fact present at the general meeting of shareholders and make their views heard, this will leact to higher attendance rates and to a considerable improvement in the quality of the general meeting of shareholders. As the attendance rate ats the general meeting of shareholders becomes more representative of the imvestors, the Committee believes that the need and justification for limiting the influence of the providers of risk capital will dimimish.'

In this "chicken-andegg" problem, we think that the argument of the OCG is more con vincing, i.e, the position of the shareholders should only be enforced if their contribution is adequate. However, the Netherlands are in the middle of this process, and still witness an increased interest from shareholders in corporate governance issues. Internationalization has made the Anglo-Saxon concepts of shareholder value and investor relations more accepted, and the larger shareholdings of institutional investors has made them reconsider their position as shareholders. This increased shareholder activism malkes a re-evaluation of the position of the shareholder in the Dutch system desirable, and this is exactly one of the things that the report of the CCG intends to do.

Independent Directors We have already stated that institutional investors arc be coming increasingly active in corporate governance issues. When they express their opinion, they are likely to take account of the interests of the people they work for, i.c., their policyholders. The VEB states this as follows: Tt is important that representatives of the institutional investors have the possibility and fresdom to focus their attontion solely in the interests of those for whom they work.

As long as the institutional investors limit thein activities to expressing then opinion in the media or in the general meeting of shareholders, there is nothing wong with this point of view. However, as we have pointed out in this chapter, directors should be able to perfom their monitoring task independently, i.e., independent from management, and independent from any interest group. Therefore, one should be reticent when considerimg. 
appointing represcutatives of institutional investors in the Board of Directors. The CCG: Members of the Board of Directors who have been appointed on the basis of a nomination should perform their duties without a mandate from those who nominated them and independently of the subsidiary interests associated with the company. This means that - like other members of the Board of Directors - they should not commit to certain subsidiary interests while neglecting other associated interests."

Being reticent in choosing diectors from any interest group is in line with our reasoning earler in this chapter that directors should be chosen on the basis of their skills, and not of their interests. The CCG: 'Tt is important that members of the Board of Directors are selected from a wide circle."

Accountability In this chapter we have argued that the report of the Board of Directors in the annual report should become more comprehensive." Both the $\mathrm{CCG}$ and the VEB support this view. More explicitly, they claim that at least information should be provided on the company's objectives, strategy and the associated risks, and the mechanisms needed to control risks of a financial nature. Only if this information is provided in sufficient detail, "a thorough exchange of ideas can take place between company executives and investors in the general meeting of shareholders." Moreover, to make sure that each company's general meeting of shareholders is the forum to which the management and the Boad of Directors report and to which they are accountable for their performance", both the CCG and the VEB propose that the approval of the anmal accounts and of the policy pursucd should be separato itiems on the agenda.

The thorough exchange of ideas supports the basic principle that whe management and the Bond of Directors stronld have the confidence of the shareholders' meeting." Earlier in this chapter we have clamed that the more detailed information in the annual report and the more active discussions in the general meeting of shareholders will result in an improved accoumbality of management and Board of Directors. For example, the better information can be put to good use if the shareholders start a disnissal procedure for a dinector in a comt of law. The VEB wants to create the possibility that a manager can be woted away (dismissed) by a qualifed majority in the general meeting of shareholders. We think that dismissing a manager should remain a task for the Board of Directors in the 
Dutch system. However, if the accountability does not improve with the proposed changes in the report of the $\mathrm{CCG}$, one could consider to allow for the dismissal of a director by the voting procedure as just described.

Incentive Compensation It is generally acceted that incentive compensation is a useful tool to align the interests of shareholders and executives. This view is shared both by the CCG and the VEB. However, implementation of incentive compensation, e.g. by means of stock option plans, should be carried out cautiously, because it can easily lead to wrong incentives, or to bold-faced enrichment of the executives. The VEB mentions three conditions that the stock option plans have to satisfy in order to make them useful from the point of view of the shareholders:

1. The option should work as a long tem incentive. The main concon of the VIB is that managers should not have the incentive to increase profits in the short run at the expense of the long term profitability of the firm. This is of course a genume concerm, but one should not forget that managers can also sacrifice short term profits in favor of long term profitability. Therefore, it is probably more apt to state that the incentives resulting from the stock option plans should balance the short term and the long term profitability. Another important concern is that stock option plans only provide the right incentives if their payoff is dependent on the specific performance of the firm, and not of general (stock) minnet conditions. This can be implemented by making the compensation dependent on relative performance measures, ice, relative to the performance of other firms in the same industry.

2. The granted stock options should be in a reasonable proportion to the fired component of the salary. This is to ensure that stock option plans are only introduced to create the proper incentives, and not to simply increase the salaries of executives to unreasonable levels.

3. Exercising the options should not result in a large increase in the owner's vinty. To avoid dilution, companies can choose to buy back their own shares on the market instead of issuing new stock. This is already common practice in the Netherlands [Herst and Rebers (1996)]. 
If these three conditions are satisfied, implementation of stock option plans will better align the interests of executives and shareholders, and therefore lead to an increased performance of the corporation. ${ }^{18}$ To ensure a proper implementation, a special Remuneration committee of the Board of Directors could periodically set down the incentive compensation plans in a separate document, which can be made subject to approval in the general meeting of shareholders. Both the $\mathrm{COG}$ and the VEB have made suggestions in this direction.

Concluding Remarks With respect to the issues that we have discussed, we think that the report of the Committee on Corporate Governance offers good prospects for improved and more up-to-date corporate governance in the Netherlands. The CCG recognizes the need for discussion, and proposes changes to improve the position of the shareholders and the accoumtability of the Board of Directors. We are sympathetic to the idea that changes in corporate governance should be gradual, if possible within the existing law. For example, whould not become too enthusiastic in reinforcing the position of the shareholder in the Dutch system by pointing at the Anglo-Saxon system. As mentioned earlier in this chapter, the Anglo-Saxon system is reassessing their position as well, and it is frequently argued that the position of the shareholder might be too strong. It is therefore advisable not to take to hasty decisions, and to place any change in the context of the whole system of corporate governance.

\footnotetext{
"Earlier in this chapter, we have already mentioned that we do not see a good reason why the CCG claims that stock option plans, or incentive compensation in general, should be implemented only for managers, and not for directors.
} 


\section{Chapter 3}

\section{When to Fire Bad managers: The Role of Collusion Between}

\section{Management and Board of Directors}

\subsection{Introduction}

Even among capitalist economies there are pronounced differences in the way corporations are run. In the United States, for example, most of the large firms are supervised by a Board of Directors. The Board of Directors is composed of outside directors as well as executive directors, who are involved in the day-to-day management of the firm. The ultmate power, however, rests with the shareholders, who alwalys have the possibility to fire the management. The Anglo-Saxon system is therefore often cited as an example of how corporate management should be organized in Continental-European countries, where shareholders have much less influence on the way the company is run.

In Continental Europe it is common to have a separation between the mantgement and the Board of Directors. In such a two-tier system, the Board of Directors often acts as an autonomous body which is beyond the control of the shareholdens.' It is frequently argued that this lack of shareholder power gives rise to situations in which the management and

\footnotetext{
"An example are the Netherlands, where only the Board of Directors has a right to appoint or to fire the management. The Board of Directors also appoints its own succossors, without interference from the shareholders [see, for example, Moerland (1995)].
} 
the Board of Directors mutually protect each other at the expense of the shareholder. In this chapter, however; we argue that such collusion between management and directors is not always bad for the shreholders.

"To show why this may be the case, consider a simple two-period model of a firm which lires manager at the start of the first period. The match between the manager and the firm may turn out to be either good or bad. The quality of the match is beyond the control of the manager or the firm: it is merely a "move by Nature". If the match is bad, the sharcholder would like to fire the manager at the end of the first period ${ }^{2}$ At that moment the manager also learns about the firing cost he will incur and for which he needs to be compensated ex ante in order to be willing to run the firm. In the ideal situation, the shareholder would observe this firing cost also and be able to commit ex ante to not firing the managen in those cases in which his firing cost exceeds the expected gain from hiring a new manager.

Rather realistically, however, we assume that the shareholder can only learn about the quallity of the match throngh the observation of the firm's first-period cash flow. Moreover, the shareholder does not observe the realization of the firing cost. Therefore, the shareholder may want to delegate the power whether or not to fire the manager to a director who monitors the company more closely and thus can make better informed decisions. If the firing cost of a (bad) manager turns out to be relatively high, he has the incentive to bribe the director not to fire him. The possibility of such collusion may be in the interest of the shareholder, becase it saves him the resources needed to compensate the manager ex unte for potentially high realizations of the firing cost. Thus, collusion avoids part of the dendweight losses associated with firing decisions. Indeed, this may be an important advantage of the Continental-European style of corporate management when compared with the Anglo-Saxon system, where manager's salaries of companies of comparable size are generally much higher [see, for example, Conyon et al. (1995), and the Economist $(19050, b))$

In practice, there are various types of costs the manager incurs when he is fired. These can talke the form of foregone income as well as the loss of resources in the process of

\footnotetext{
2 With some slight abuse of terminology, we will refor to the ruanager as being good (bad) if the quality of the match between the manager and the form is good (bad).
} 
searching for a new job and moving to another place. But there may also be other, less tangible costs, such as the loss of reputation and valuable contacts. It is reasonable to assume that these costs are, at least partly, unknown ex ante, for example because it is not clear what the manager's job market position or legal position will be in the future.

For simplicity, the model assumes that collusion between the manager and the director takes place through a monetary transfer from the fomer to the latter. In reality, howewer, such a bribe would often be less tangible. For example, in a corporate system with inturlocking directorships and strong informal ties across firms the manager might recommend the dinector at other firms for a dinectorship. Another example would be a tightening of buyer-seller relations between the manager's firm and frms in which the directom has a stake or of which he is manager himself.

This chapter is related to a primcipal-agent literature which focuses on designing compensation schenes that a shareholder can use to extract the optimal level of effort from a manager. This standard model has been extended to incorporate a supervisor as another layer between the principal and the agent [e.g. Baron and Besanko (1984)]. Acconding to Kofman and Lawarree (1993), however, "the reseanch in this area has by and large neglected the possibility of collusion."

An important exception is Tirole (1986), who adds a set of 'coalition incentive com. patibility constraints' to the usual individual rationality and incentive compatibility constraints, such that the final allocation is coalition proof Kofman and Lawareo (1990) develop a model in which it may be optimal for the principal to allow for collusion. How. ever, this result is obtained because deterring collusion is costly in their model. In contrast, in our model, even if it is costless to prevent collusion, allowing for collusion between management and director can be beneficial to the principal. ${ }^{4}$

Our argument is developed in the following steps. Section 3.2 presents the besic model. In Section 3.3 we study the benchmark case of a shareholder who, after one period, can observe the manager's type (good or bad) as well as his firing cost. Moreover , the shareholdor

\footnotetext{
${ }^{3}$ For example, Ross (1973), Holmstrom (1979), Grossman and Hart (1983), and Holmstron and Milgrom (1987). For empirical evidence on incentive compensation, see, for example, Jensen and Murphy (1990) and Garen (1994).

"For other examples where collusion can be in the interast of the principal, see for bxample the excellent survey by Tirole (1992).
} 
is wble to commit at the start of the fist period (wher contracts are signed) to a firing rule based on the realization of the hring cost. This is the ideal situation with the highest payof for the shareholder. Section 3.4 relaxes the assumption that the shareholder can observe the type and the fring cost of the manager. The shareholder receives only a noisy aignal in the form of a realization of the fim's cash flow. He therefore fuxes a threshold for the cash flow. If the cash flow is below (above) this threshold he fires (retains) the manager. The next step (Section 3.5 ) then is to delegate the fining decision to a director, who has an information adwantage because he monitors the manager more closely. The salary of the director depends on the cah flow of the firm. The manager receives a fixed sallary as well as a fixed severance payment which is paid only when he is fred. Because a higher severance payment reduces the incentive of a bad manager to bribe the director, the shareholder would want to set it as high as possible if collusion is undesirable. However, in those cases where it is desirable to allow for collusion, the severance payment will help to ensure that firing fakes place only when the realized firing cost is relatively low. Section 3.6 explores under what conditions the shareholder would allow collusion, even if he were able to prevent it (e.g., through intensified monitoring of the director) without any cost. Section 3.7 concludes the chapter.

\subsection{The Basic Model}

We consider a two-period model without disconnting and in which all agents are risk neutral. Qualitatively speaking, the assumption of risk neutrallity does not affect our rosults. A firm is owned by a shareholder, who randomly selects a manager at the start of the first period. The cash flow generated by the firm in any given period depends on how the frrm and the manager fit together. At the moment the manager is selected neither he nor the shareholder knows how good the match will be. A manager fits the frm well if he is 'the right man at the right time at the right place'. Such a manager is called a 'good' manager. A manager that does not fit the firm well is called a "bad" manager.

The firm's cash flow in a given period, $x$, is stochastic. It depends not only on the type of the manager but aso on random factors which are beyond his control. If the manager is good, the distribution of the cash flow is described by a density function $f_{c}(x)$. Similarly, 
if he is bad, the density function of the cash fow is $f(x)$. Details about the density functions are reported in Figure 3-1. Both density functions are restricted to the domain $[0, X], X>0$. They are linear with a slope $\frac{2}{X^{2}}$ for the good manager and slope $-\frac{2}{x^{2}}$ for the bad manager. Thus, a good managen has a higher probability of producing a higher cash fow. The expected cash flow of the firm when the manager is good (bad) is $\mu_{Q}\left(\mu_{B}\right)$. Without loss of generality we assume that the a priori probabilities of the manager being good or bad, $\operatorname{Pr}\{G\}$ and $\operatorname{Pr}\{B\}$, respectively, are both equal to $\frac{1}{2}$. Hence, the expected cash flow generated by a randomly selected manager is $\bar{\mu} \equiv \operatorname{Pr}\{B\} \mu, \operatorname{Pr}\{G\} \mu_{G}$. Because of the assumed symmetry, $\mu_{Q}-\bar{\mu}=\bar{\mu}-\mu_{B} \equiv \Delta \mu$. Hence, $\Delta \mu$ is the (absolute) dilterence between the average expected cash flow and the expected cash flow under a good or bad manager.
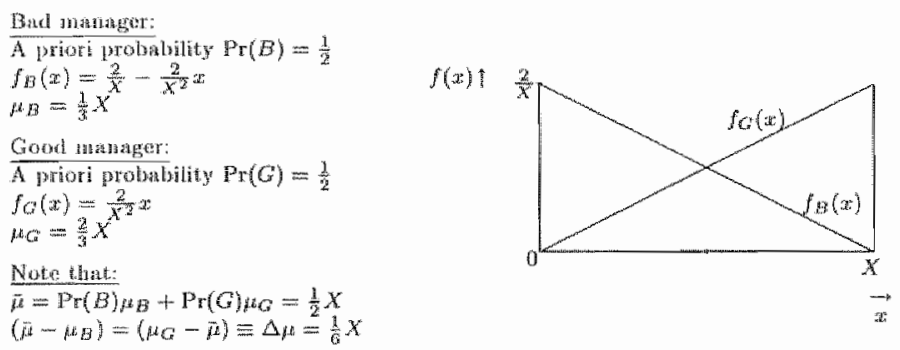

Figure 3-1: The cash fow density functions of the two types of managers.

Managers have a reservation wage of $\mathbb{W}_{m}>0$ in edcli period. At the end of the first period, the manager can either be retained or be fired and replaced by another manager. This decision will of course depend on the available information about the lype of the manager, as we will see below. A manager who is fired incurs a personal firing cost $c$. The fring cost is stochastic and uniformy distributed on the interval $[0, O]$. We assume that it is (statistically) independent of the cash flow under either type of manager. Tho realization of the firing cost is revealed to the manager at the end of the first period.

To induce the manager to run the firm he must be compensated somehow for his expected firing cost, which we denote by $c^{e}$. Of course, ctepends on the probability that. the manager will be fired. This, on its turn, depends on the specific arrangements (e.g., a 
director who cun be bribed) to be considered below. Comperusation takes place through a fixed salary $s$, and f fixed severance payment, $p \geq 0$, which the manager receives in the case ha gets fired. Herce, in the first perod hiss participation constraint is given by:

$$
W_{m} \leq s+p^{e}-c^{e}
$$

whare $p^{\prime \prime}$ is his expected severance payment (which depends also on the probability that the manager will be fred).

If the manager is not fired at the end of the first period, he will receive a fxed wage $W_{n}$ in the second period. If he is fired, he is assumed to be able to obtain his second-period reservation wage somewhere dise.

\subsection{The First Best}

The shareholder's payolf is maximized if he can observe perfectly both the type of the manager and his firing cost at the end of the first period, and if he can commit ex ante (i.e., at the start of the first period when contracts are signed) to a firing rule which depends on the realized firing cost. "The resulting solution will be termed the forst best."

Firing a bad manager and replacing him with a randomly selected new manager at the end of the first period raises the expected cash fow of the firm in the second period by $\Delta \mu$, while firing a good manager reduces the expected future cash fow of the firm by $\Delta \mu$. To induce a manager to run the firm, he has to be compensated for his expected firing costs. While ex post the shareholder would always want to fire a bad manager, from an aname point of vew, in those cases where the realized firing cost exceeds the expected increase in the second-period cash flow of the furm, the shareholden would not want to fure the minager.

Suppose first that $C \leq \Delta \mu$ (see Figure 3-2(a)). Even from an ex-ante point of view the

\footnotetext{
"Note that if the firing decision does not depend on the value of $p$, compensation for expected firing costs could instead take place through a ligher $s$. The distinction between $s$ and $p$ becomes relevant only in Section 3.5 .2 .

GStrictly speaking, the ideal situation for a shareholder would be if he knew the type of the manager at the start of the first period. "This case is trivial and is, therefore, neglected.
} 
(a)

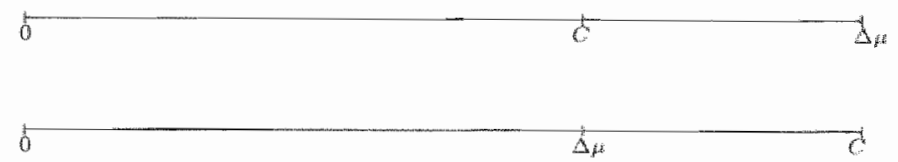

Figure 3-2: The relevant configurations of $C$ and $\Delta \mu$ for the optimal firing decision.

shareholcler would always want to fire a bad manager. Hence, the value of commitment to an optinal firing rule, based on the realized fring cost, is zero.

Now suppose that $C>\Delta \mu$ (see Figure 3-2(b)). Ex ante it would be optimal to fire only if $c<\Delta \mu$ and not to fire if $c \geq \Delta \mu$. The walue of commitment for the shareholder is the sum of two components. The first component is the reduction in the compensation that the manager requires for the expected firing cost he incurs, $\frac{1}{2} C-\frac{1}{2}\left(\frac{\Delta \mu}{C}\right) \frac{1}{2} \Delta \mu$, where $\bar{C} \equiv E[C]=\frac{1}{2} C$. Here, $\frac{1}{2} \bar{C}$ is the compensation he requires if he is always fired when he turns ont to be bad. If the shareholder can commit himself to only firing a bad manager if $c<\Delta \mu$, the manager requires a compensation of $\frac{1}{2}\left(\frac{\Delta \mu}{C}\right) \frac{1}{2} \Delta \mu$. This is the probability that he is bad, $\frac{1}{2}$, times the probability that $c<\Delta \mu$, times the expected firing cost conditional on $c<\Delta \mu$, which is $\frac{1}{2} \Delta \mu$. The second component is (minus) the reduction in the expected second-period cash flow from not always firing a bad manager in the case of commitment, $\frac{1}{2} \Delta \mu-\frac{1}{2}\left(\frac{\Delta_{r}}{C}\right) \Delta \mu$. Always (instead of never) firing a bad manager raises the expected cash flow with the probability that the manager is bad, $\frac{1}{2}$, times the expected increase in the cash flow from firing the bad manager, $\Delta \mu$. Only firing a bad manager if $c<\Delta \mu$, merely raises the expected cash. flow by the probability that the manager is bad, times the probability that $c<\Delta \mu, \frac{\Delta \mu}{C}$, times the expected increase in the custu flow from firing the bad manager. Hence, the value of commitnent is:

$$
\left[\frac{1}{2} \bar{C}-\frac{1}{2}\left(\frac{\Delta \mu}{C}\right) \frac{1}{2} \Delta \mu\right]-\left[\frac{1}{2} \Delta \mu-\frac{1}{2}\left(\frac{\Delta \mu}{C}\right) \Delta \mu\right]=\frac{1}{4} \frac{\left(C-\frac{\Delta \mu)^{2}}{C}\right.}{C} .
$$

Not surprisingly, for given $\Delta \mu(<C)$ the value of commitment is increasing in $C$. 


\subsection{No Director}

From now on we assume that the shareholder nether observes the type of the manager, nor his fring cost at the end of the first period. Therefore, the only information upon which the shareholder can base his firing decision is the realization of the first-period cash flow, $x_{1}$. More specifically, at the start of the first period the firm and the manager sign a. contract which specifies axed threshold $\tau$ for $x_{1}$. The manager will be fired at the end of the first period if and only if $x_{1}<\tau$.

The sharcholder chooses the threshold $r$ so as to maximize his expected payoff: The only relevant variables that enter his objective function are the expected cash flow of the firm in the second period, denoted by $x_{2}^{e}$, the fixed sallary of the manager in the first period, and the expected severance payment at the end of the first period. These are the wariables that depend on the firing decision, and, hence, are affected by the threshold. Because there is no reason to pay the manager more than his reservation wage, the participation constrint of the manager will be binding. Hence, using (1) with equality, one has:

$$
S V=x_{2}^{e}-s-p^{e}=x_{2}^{e}-W_{m}-c^{e}
$$

where $S V$ is the shareholden value. Throughout, we thus ignore the manager's secondperiod salary as well as the contribution of the expected first-period cash flow ( $\mu$ ) to the sharoholder walue. This is irrevent for any of the results.

In the Appendix we show that (3.3) can be rewritten as:

$$
S V=\mu-W_{m}+\frac{1}{2}\left[F_{B}(\tau)-F_{O}(\tau)\right] \Delta \mu-\frac{1}{2}\left[F_{B}(\tau)+F_{G}(\tau)\right] C
$$

where $F_{B}(\cdot)$ and $F_{G}(\cdot)$ are the distribution functions corresponding to $f_{B}(\cdot)$ and $f_{C}(\cdot)$, respectively.

The intuition for (3.4) is as follows. If the shareholder would never fire a manager

\footnotetext{
Tho assume also that, in the absence of a director, the manger is mot able to observe his own type at. tha end of the fret period. This prectudes the possibility of a lowg-terra rewelation contract between the

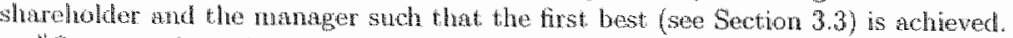

bone can show that the optimal hreshd yalds be highest payof to the shareholder of all possible contrats where the choice to fre or mot is based on $x_{1}$ only.
} 
$(\tau=0)$, the shareholder value is simply the average cash flow of the fin minus the reservation wage of the manager $\left(\bar{\mu}-W_{m n}\right)$. If a threshold $\tau>0$ is imposed, the shareholder will fire a bad manager with probability $\frac{1}{2} F_{B}(\tau)$, which is the probability that the manager is bad times the probability that $x_{1}<t$, given that the manager is bad. Similarly, the shareholder will fire a good manager with probability $\frac{1}{2} F_{G}(\tau)$, which reduces the expected second-period cash flow by $\Delta \mu$. Finally, the expected cost of setting a threshold is $\frac{1}{2}\left[F_{B}(\tau)+F_{G}(\tau)\right] \bar{C}$. This is the probability that the manager is fired, $\frac{1}{2}\left[F_{B}(\tau)+F_{G}(\tau)\right]$, times his average firing cost, $\bar{C}$.

Differentiating the righth-hand side of (3.4) yields the necessary and, in this case, sufficient first-order condition for $\tau$ :

$$
\bar{C}=\left(\frac{f_{B}(r)-f_{G}(r)}{\left.f_{1 S(T)+f_{G}(\tau)}\right)} \Delta \mu\right.
$$

Hence, the optimal threshold, denoted by $\tau^{*}$, is:

$$
\tau^{*}=\frac{1}{2} X\left(1-\frac{\check{G}}{\Delta \mu}\right), \text { if } \bar{C}<\Delta \mu
$$

where we have used the distributional properties reported in Figure 3-1. If $\vec{C} \geq \Delta \mu$, the shareholder sets $\tau^{*}=0$. Because the expected firing cost exceeds the expected increase in the cash flow of the firm in this case, it is optimal not to impose a positive threshold. Equation (3.6) shows that the threshold is always below $\frac{1}{2} X$. Moreover, $\tau^{*}$ is positively related to $\Delta \mu$ and negatively related to $\bar{C}$. An increase in $\Delta \mu$ raises the likelihood that a below-average performance, i.e. $x_{1}<\frac{1}{2} X$, can be attributed to the manager being bad. Ceteris paribus, an increase in $\bar{C}$ raises the expected firing cost for the manager and thus requires the shareholder to offer him a higher salary. To compensate for this, the shareholder sets a higher threshold, thereby reducing the probability that, the manager will be fired.

Finally, for $\tau=\tau^{*}$, the shareholder value is (see the Appendix):

$$
S V= \begin{cases}\bar{\mu}-W_{\mathrm{m}}+\frac{1}{4} \Delta \mu-\frac{1}{2} \bar{C}\left(1-\frac{1}{2} \frac{\bar{C}}{\Delta \mu}\right), & \text { if } \bar{C}<\Delta \mu \\ \bar{\mu}-W_{\mathrm{m}}, & \text { if } \bar{C} \geq \Delta \mu\end{cases}
$$


Higher average firing costs reduce the shareholder walue (if $\bar{C}<\Delta \mu$ ). The reason is that the shareholder has to compensate the manager for the higher expected firing cost by increasing his salary arcordingly.

The current arrangement involving a threshold is dominated by the first best (see Section 3.3) for two reasons. The first is that the shareholder no longer perfectly observes the type of the manager. He can make either one of two errors: firing a good manager or not firing a bad manager. The second reason is that, because the shareholder does not observe the realization of the firing cost, he cannot commit himself to not fring the manager if $2 \geq \Delta \mu$.

\subsection{Introducing a Director}

From now on, the shareholder can delegate the fring decision to a director. The director may be expected to have more information about the manager than the shaveholder. According to Fama (1980), the director can be viewed as a market-induced institution, "[...] whose most important role is to scrutinize the highest decision makers in the firm." In his role of monitoring the manager, the director can obtain and use confidential information about the firm and the manager. This information is not always at the disposal of the shareholders, for example in order to avoid that competitors would profit from it. In parLicular, we assume that the director can olsserwe the type of the manager perfecty at the end of the first period. This assumption may be motivated by the fact that the director ofter is a director at oher firms as well. Comparing the perfornance of these other firms with the fin under consideration enables the director to infer whether the manager is good or bad. Finally, we assume that also the manager limaself observes his type at the end of the first period. This should not be unreasonable for a firm in which the nanager interacts with his director on a sufficiently frequent basis.

The reservation wage of the dinector is $W_{t}>0$. We assume that $W_{\text {d }}$ is not too large, because otherwise it would not be profitable to have a director at all. Specifically, it turns out that the following restriction will be convenient:

$$
W_{a} \leq\left(\bar{\mu}+\frac{1}{2} \Delta \mu\right) \operatorname{Min}\left[1, \frac{c}{\Delta \mu}\right]
$$


We assume that the director receives a proportion $\alpha \geq 0$ of the second-period cash flow of the firm. This should give him an incentive, albeit not always perfect, to make the appropriate firing decision from the viewpoint of the shareholder. Sucll a simple, linear incentive scheme cau be motivated as follows. First, it captures the spirit of most of the incentive schemes implemented in practice, namely providing a simple link between reward and performance. Second, it yields the basic result of this chapter, i.e, that collusion can be beneficial for the shareholder. This result also holds for more sophisticated incentive schemes (see Footnote 12 below).

We adopt an incomplete contract approach." That is, our starting point is that there is a director who takes a firing decision which maximizes his compensation. Given this, we will investigate the potential for collusion between the manager and the director. Moro specifically, we allow for the possibility that the manager offers a bribe to the director in order to influence his firing decision.

The shareholder value, the participation constraint of the manager, and the participation constraint of the director, are given by, respectively:

$$
\begin{aligned}
& S V=x_{2}^{e}-s-p^{e}-\alpha x_{2}^{e} \\
& W_{m} \leq s+p^{e}-c^{e}-b^{e} \\
& W_{d} \leq \alpha x_{2}^{e}+b^{e}
\end{aligned}
$$

where $b^{e}$ is the expected bribe paid by the manager to the director in order to influence his firing decision.

\subsubsection{No Collusion}

For the moment, we disregard the possibility of collusion. Hence, $b^{e}$ drops out of (3.10) and (3.11). Therefore, the payoff to the director depends only on the second-period cast How of the firm. Hence, for any $a>0$, the director will always fire a bad manager, but never fire a good manager. Therefore, firing takes place with probability $\frac{1}{2}$. This implics

\footnotetext{
${ }^{9}$ For an intuitive introduction to incomplete contracts, see Hast (1995). For a racent survey, see Tirole (1994).
} 
thes $x_{2}=\frac{1}{2} \mu+\frac{1}{2} \mu_{G}=\vec{\mu}+\frac{1}{2} \Delta \mu$. The expected fring cost is $\frac{1}{2} \vec{C}$, which is the probability What a manager is bad multiplied by the average fring cost.

Define $\alpha$ as the minimum value of $\alpha$ for which the participation constraint of the director, (3.11), is Balisfied. Hence,

$$
\alpha^{i n}=\frac{W_{u}}{\mu+\frac{1}{2} \Delta \mu}>0 .
$$

Olsserve that $\alpha^{0} \leq 1$, as implied by (3.8). Because the firing decision of the director is independent of $\alpha$ (if $a>0$ ), it is optimal for the shareholder to set $\alpha=\alpha^{0}$. Combined with the fact that (3.10) is binding, this implies that:

$$
S V=\bar{\mu}+\frac{1}{2} \Delta \mu-W_{m}-\frac{y}{2} \bar{C}-W_{d}
$$

To compare this with the shareholder value in the absence of a director, one has to distinguish between the case in which the shareholder would choose to set $\tau^{*}=0$ (i.e., if $\bar{C} \geq \Delta \mu$ ) and the case in which he would set $\tau^{*}>0$ (i.e., if $\bar{C}<\Delta \mu$ ).

$\overline{\mathrm{C}} \geq \Delta \mu:$ Comparing (3.13) and the second line of (3.7), we see that the shareholder wonld want: to hire a director if and only if:

$$
W_{d} \leq \frac{1}{2}(\Delta \mu-\breve{C})
$$

Honce, in this case $(C \geq \Delta / 4)$, the shareholder would never hire a director. The intuition is straghtorward. The diretor, who observes the type of the manager perfectly, will always fre a bad manager. However, he does not take into account the (ex-ante) compensation that the manager requires for he expected fring cost, $\bar{C}$, which exceds the increase in the wpected second-period cash flow from always firing a bad manager.

$\mathrm{C}<\Delta \mu$ : Comparing (3.13) and the first line of (3.7), it follows that the shareholder would hire a director if and only if:

$$
W_{a} \leq \frac{1}{4} \Delta \mu\left[1-\left(\frac{C}{\Delta ! L}\right)^{2}\right]
$$

Because the right-hand side of $(3.15)$ is positive, a director is hired if his reservation wage 
is not too high. Hiring a director is more profitable if $\Delta \mu$ is larger and if the average fimg cost, $\bar{C}$, is lower.

\subsubsection{Collusion}

Now we allow for the possibility that the manager pays a bribe to the director at the end of the first period in order to hnfuence his fring decision. The shareholder takes this Into account when setting the compensation schemes at the start of the first period. He optimizes over $\alpha, s$ and $p$. Because the severance payment is paid only when the manager is fired, it will affect the expected bribe. Hence, there is an independent role for the severance payment now.

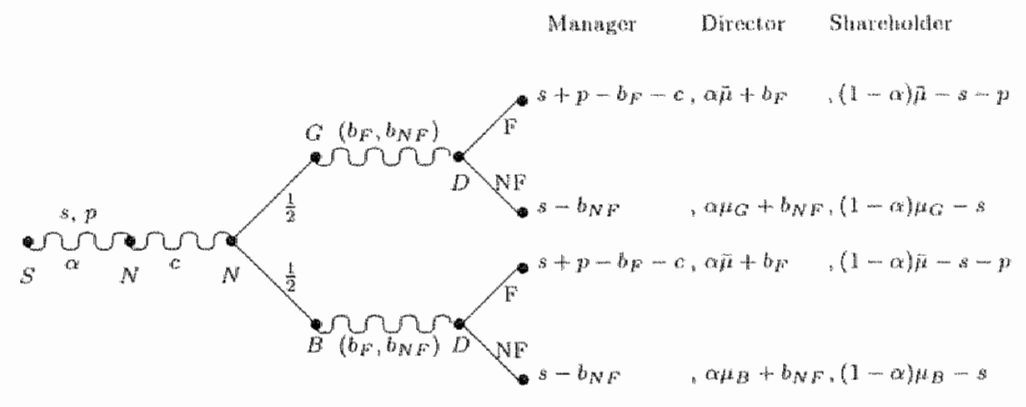

Figure 3-3: Extensive form representation of the gane if collusion is possible.

Figure 3-3 shows the extensive fom representation of the new game. At the stat of the first period the shareholder (S) selects $\alpha, p$ and $s$. At the end of the first perion there is a move by nature (N) concerning the realization of the firing cost, c, and the type of the manager. The manager, $\mathrm{C}(\mathrm{ood})$ or $\mathrm{B}(\mathrm{ad})$, each possibility with probability $\frac{1}{2}$, can then ofter a 'take-it-or-leawe-it' bribe to the director in order to infuence his firing decision. The ofer is denoted by the combination $\left(b_{F}, b_{N F}\right)$ and has the following form: "I pay you br: if you fre me and bNF if you do not fire rue." On the basis of this offer, the director either" fires (F) the manager or does not fire (NF) him (decision nodes D). We assume that the manager and the director both skick to the agrement, if the lat ter accepts the ofler.

Figure 3-3 also shows the (expected) payoffs for each outcome. As before, wa indude only those wariables that are affected by the actions in the game tree. It in easy to dorive 
the payofs from equations $(3.9)$ to (3.11). Because the game is one of perfect information, we can use backwards induction to solve for the Subgame Perfect Equilibria.

The first step is to investigate the incentives of the director to fre at the end of the first period. In Section 3.5.1 we saw that in the absence of collusion the director will always fire a bad manager and never fre good managet. If collusion is allowed, both a bad manager and a good manger may have an incentive to bribe the director in order to change his firing intentions. A bad manager would be prepared to offer a bribe of up to $(c-p)$ if this induces the director not to tre him. The director aceepts this bribe if it is not lower than his expected gain from fring ( $\alpha \Delta \mu$ ). Therefore, if $c \geq p+\alpha \Delta \mu$, the bad namager successfully offers a bribe of $\alpha \Delta / i$ and is not fired. A good manager would be prepared to offer a bribe of up to $(p-c)$ if this induces the director to fre him. This bribe is accepted if it aquals or exceeds the director's expected loss from firing a good manager $(\alpha \Delta \mu)$. Therefore, if $c \leq p-\alpha \Delta \psi$, the good manager successfully offers a bribe of $\alpha \Delta \mu$ and is fired.

However, we argue that at, an optimum $\left(\alpha^{*}, p^{*}\right)$ it should be the case that $p^{*} \leq \alpha^{*} \Delta u$ : hence, a good manager is never fired. Suppose that the opposite holds. Then, for every realization of $c$ smaller than $\left(p^{*}-\alpha^{*} \Delta \mu\right)$, a good manager will succeed in bribing the director to fire him. However, such a value for $p$ cannot be optimal: reducing $p$ to $\alpha^{*} \Delta \mu$ increases the probability that a bad manager is not fred, but, to the same extent, also decreases the probubility that a good mamager is fired. Therefore, the net effect on the expected cash flow of the fim is nil, while the expected firing cost is reduced (so that $s+p^{e}$ is reduced).

A bad manager is fired with probability $\frac{2+\alpha \Delta}{C} \leq 1$. This inequality holds at an optimum becuse any choices of $p$ and $\alpha$ such that $p+\alpha \Delta \mu>C$ can be improved upon by decreasing a: this does not change the incentives for the director but it increases the shareholder value. Hence, one has:

$$
\begin{aligned}
& x_{2}^{e}=\frac{1}{2} \mu_{G}+\frac{1}{2}\left(\frac{C-p-a \Delta \mu_{\mu}}{C} \mu_{G}+\frac{p+a \Delta \mu}{C} \mu\right)=\tilde{\mu}+\frac{1}{2} \frac{p+a \Delta \mu}{C} \Delta \mu_{1} \\
& p^{e}=\frac{\mathbb{1}}{2} \frac{1+\alpha \Delta t}{C} p \\
& c^{t}=\frac{1}{2} \frac{\tan \Delta x}{C} \frac{1}{2}(p+\alpha \Delta \mu)
\end{aligned}
$$




$$
b^{e}=\frac{1}{2} \frac{C-p-\alpha \Delta z}{C} \alpha \Delta \mu
$$

The director receives a proportion $\alpha$ of the expected cash flow of the firm, plus the expected bribe from the manager. Using (3.16) and (3.19) the director's expected payoff is:

$$
a x_{2}^{e}+b^{e}=\alpha\left(\bar{\mu}+\frac{1}{2} \Delta \mu\right)
$$

The expected payoff depends only on $\alpha$ and not on $p$. This is not surprising. The expected second-period cash flow of a firm with a director who always fires bad managers and never fires good managers is $\frac{1}{2} \mu+\frac{1}{2} \mu_{G}=\bar{\mu}+\frac{1}{2} \Delta \mu$. If a director is bribed into not firing an bad manager, the expected cash fow decreases. Hence, for a bribe to be successful, it must at least compensate the director for his loss from a reduced expected cash flow. However, the manager will offer the lowest possible bribe, which is the one that exactly compensates for this loss.

Because $p^{*} \leq \alpha^{*} \Delta \mu,(3.17)$ and (3.18) imply that $p^{e} \leq c^{e}$. In addition, because $W_{m}>0_{1}$ one has (by (3.10)) that $s>0$. However, because $s$ cloes not affect the firing decision of the director, the shareholder can set $s$ such that the participation constraint of the manager (3.10) is binding.

Finally, combining (3.9), (3.10, with equality), (3.16), (3.18), and (3.20), we obtain the following expression for the shareholder value, which is to be maximized over $\alpha$ and $p$ :

$$
S V=\bar{\mu}+\frac{1}{2} \frac{p+\alpha \Delta \mu}{C} \Delta \mu-W_{n}-\frac{1}{2} \frac{p+\alpha \Delta \mu}{C} \frac{1}{2}(p+\alpha \Delta \mu)-\alpha\left(\mu+\frac{1}{2} \Delta \mu\right)
$$

From (3.20), $\alpha^{0}$ as defined by (3.12) is again the minimum value of $a$ for which the participation constraint of the director is binding. Furthernore, define $\bar{\alpha}$ as the optimum for $\alpha$ if we ignore the participation constraint for the director. In the Appendix we prove the following two lemmas:

Lemma 1 Suppose that $\Delta \mu>C$, that is, the expected difference between the cash flow generated by a good or a bad manager and the cash flow of an average mavager exceds the maximum firing cost. 
1. If $\bar{\alpha} \leq \alpha^{b}$ (2.e, the participation constraint of the director is binding), then $\alpha^{*}=\alpha^{0}$. In this case, $p^{*}$ is equal to the minmum of $\alpha^{0} \Delta \mu$ and $C-\alpha^{0} \Delta \mu$.

2. If $\ddot{a}>\alpha^{0}$ (i, $\mathrm{E}$, the perticipation constraint of the director is not binding at the optimal unconstroined $\alpha$, then $\alpha^{*}=\alpha$ and $p^{*}=\alpha \Delta \mu$ at the optimal solwtion.

Hers, $\tilde{\alpha}=\max \left[0, \min \left(\frac{2 \Delta \mu-7 C}{4 \Delta \mu}, \frac{C}{2 \Delta \mu}\right)\right]$

Lemma 2 Suppose that $\Delta \mu \leq \mathrm{C}$, that is, the maximum fining cost exceds the expected differerce beween the cosh fow generated by a good or a bad manager and the cash flow of an awerage manager. Then, $\alpha^{*}=\alpha^{0}$ and $p^{*}$ ss the minmam of $\alpha^{0} \Delta \mu$ and $\left(1-\alpha^{0}\right) \Delta \mu$.

The intuition for lamma $1-1$ is as follows. If $\tilde{\alpha} \leq \alpha^{0}$, the shareholder has to set $\alpha$ at $a^{3}$, because a lower value for $\alpha$ violates the participation constraint of the director, while a higher value for $\alpha$ rednces the shareholder walue, as follows from the clefinition of $\tilde{a}$. Because $\Delta \mu>C$, firing a bad manager is (ex-ante) efficient for every realization of $c$. Given that a bad mangger will not be fired if $c \geq p^{*}+\alpha^{*} \Delta \mu$, the shareholder sets $p$ as high as possible, with the exception that $p^{*}$ cannot be higher than $\alpha^{*} \Delta \mu$. Otherwise, a good manager wonld get fred with positive probability. This is not optimal, as we argued earlier. If $\tilde{\alpha}>\alpha^{0}$ (Lemma 1-2), then, again by definition of $\tilde{\alpha}$, the shareholder sets $\alpha=\tilde{\alpha}$. As in Lemma 1.. 1 , he wants to set $p$ as high as possible. "That is, he sets $p=\tilde{\alpha} \Delta \mu .{ }^{10}$

Alhough form an wx-ante perspective it would always be optimal to fre a bad manager, under the optimal arrangement $\left(\alpha^{*}, p^{*}\right)$ collusion will occur with positive probability whonover $p^{*}=\alpha^{*} \Delta \mu$. The resson is as follows. The shareholder would rather set the severunce pumment higher in those cases. However, this would result in a good manager being fired with positive probability.

Now, suppose that $\Delta x \leq C$ (Lemma 2). In this case, firing a bad manager is ex-ante effcicnt only if $c \in[0, \Delta \mu]$, because if $c>\Delta \mu$, the fring cost exceeds the expected increase in the future cash flow. Under the optimal arrangement $\left(\alpha^{*}, p^{*}\right)$ collusion will always occur with positive probability. To awoid that a good managen can get fred, the shareholder sets

\footnotetext{
"The fun part of the Lemma 1 implins that $\alpha \leq C /(2 \Delta \mu)$. The intution is as follows. Suppose that Whe opposite is me, i.e a $>C /(2 \Delta$, . In that case, the shareholder can decrease and simulaneously ancesse $p$ whout chughe the tring decision of the director. This yields the same expected cash flow, but a buer expected salay for the diector, which contradicts the optimality of $\alpha$.
} 
$p$ at $\alpha^{0} \Delta \mu$, if $\alpha^{0} \Delta \mu<\left(1-\alpha^{0}\right) \Delta \mu$. Otherwise, he sets $p=\left(1-\alpha^{0}\right) \Delta \mu$, which prevents collusion between the bad manager and the director if $0<c \leq \Delta \mu$, but induces them to collude if $c>\Delta \mu$.

\subsection{When is it Optimal to Allow for Collusion?}

Suppose that the shareholder is able to (costlessly) prevent the possibility of collusion, for example through intensified monitoring of the director or through provisions in the corporate charter or the corporate law which make it easier to punish a director for bad decisions. Under what circumstances should the shareholder prevent collusion?

To address this question, we need to distinguish between $\Delta \mu>C$ and $\Delta \mu \leq C$. If $\Delta \mu>C$, then firing a bad manager is allways eficient from an ex-ante perspective. This is precisely what a non-colluding director establishes. Hence, in this case, it would be optimal to prevent collusion.

Now, suppose that $\Delta \mu \leq C$. Hence, if $c \in[\Delta \mu C]$, fring a bad manager would no longer be efficient from an ex-ante perspective. A colluding director is bribed by a bad manager if $c \geq \alpha^{*} \Delta \mu+p^{*}$. As discussed in Section 3.3, this is bad for the shareholder if $c \in\left[\alpha^{*} \Delta \mu+p^{*}, \Delta \mu\right)$, but it is beneficial for him if $\left.c \in[\Delta \mu, C]\right]^{1 .}$

To see whether preverting the possibility of collusion may be in the interest of the shandolder, we compare his losses (relative to those under the first best, see Section 3.3) for the case where collusion is allowed with those for the case where it is prevented. The frst best requires that a bad manager be fired if and only if $a \in[0, \Delta \mu]$. Whan collusion is prevented, a bad manager is fired also when $c \in[\Delta \mu, C]$. The expected loss (relative to that for the first best) associated with prevention is:

$$
\frac{1}{2} \frac{C-\Delta \mu}{C}\left[\frac{1}{2}(C+\Delta \mu)-\Delta \mu\right]
$$

which is the probability that a manager is bad, $\frac{1}{2}$, multiplied by the probability that the firing decision would be (ex-arte) inefficient, $\frac{Q-\Delta \mu}{C}$, multiplied by the expected loss associated with inefficient firing, $\frac{1}{2}(C+\Delta \mu)-\Delta \mu$.

\footnotetext{
${ }^{11}$ Note that $\alpha^{2} \Delta \mu+p^{*} \leq \Delta \mu$, as follows from Lemma 2 .
} 
When collusion is allowed, it takes place whenever the manager is bad and $c \geq \alpha^{*} \Delta \mu+$ $p^{*}$. The optimal arrangement $\left(\alpha^{*}, p^{i}\right)$ in Section 3.5 .2 thus makes a trade-off between having collusion from time to time when this would not be ex-ante efficient, i.e., if $c \in\left[\alpha^{*} \Delta \mu+\right.$ $p^{*}, \Delta \mu$, and collusion occurring when this is indeed ex-ante efficient, $i$.e., if $c \in[\Delta \mu, C]$. Hence, the difference between the case where collusion is allowed and the first best (see Section 3.3) is that in the former case a bad manager is not fired if $c \in\left[\alpha^{*} \Delta \mu+p^{*}, \Delta \mu\right]$. If $\left(1-\alpha^{0}\right) \Delta \mu \leq \alpha^{0} \Delta \mu$, this interval is empty (as follows from Lemmas 1 and 2 ) and the solution with collusion being allowed in fact coincides with the first best. In the following we therefore assume that $\left(1-\alpha^{0}\right) \Delta \mu>\alpha^{0} \Delta \mu$. Compared with the first best, the loss associated with allowing for collusion is:

$$
\frac{1}{2} \frac{\Delta \psi^{i}-\left(\alpha^{*} \Delta \psi^{\alpha}+p^{*}\right)}{C}\left[\Delta \mu-\frac{1}{2}\left(\Delta \mu+\alpha^{*} \Delta \mu+p^{*}\right)\right]
$$

which is the probability that a manager is bad, $\frac{1}{2}$, multiplied by the probability that not firmg a bad manager would be (ex-ante) inefficient, $\frac{\Delta \mu-\left(\alpha^{*} \Delta_{\mu}+p^{*}\right)}{C}$, multiplied by the expected opportunity cost of not firing a bad manager, $\Delta \mu-\frac{\mathbb{1}}{2}\left(\Delta \mu+\alpha^{*} \Delta \mu+p^{*}\right)$.

Expression (3.22) is increasing in $C$, while expression $(3.23)$ is decreasing in $C$. Hence, a larger value of $C$ increases the desirability of allowing for collusion. Fon $C$ sufficiently large, expression (3.23) is smaller than expression (3.22), i.e., allowing for collusion is better than preventing collusion. The reason is that the possibility of collusion offsets part of the loss associated with the failure to commit to not fring a bad manager if his firing cost is relatively high. ${ }^{12}$

\subsection{Concluding Remarks}

In this ather we have argued that collusion between the Board of Directors and the managenent of a firm is not always bad for the shareholders of the firm. In particular:

\footnotetext{
Wot that any incentive scheme for a director with positive relation between $x_{2}$ and his salary gives him the incontive never to hre a good nanger, and always to fire a bad manger. As in the case of a linear incentive schome, it, would then be efficient to have collusion if $a \in[\Delta \mu, C]$. Hence, although one might be able to devise better incentive schemes (rom the shareholder's perspective) than the linear scheme, this does not change the basc insight that it my be proftable to allow for colusion.
} 
collusion alleviates the costs associated with the failure to commit to not firing a bad manager if his personal firing cost is relatively high. The possibility of collusion reduces the compensation required by the manager.

Our analysis may explain why management salaries are substantialy higher in the Arglo-Saxon system than in many other combries. In the Anglom Saxon system, managers require more compensation because of a higher risk to be fined. This arises from the fach that it is relatively easy for shareholders to fire a manager.

An interesting direction for further research would be tro allow for the possibility to fre the director in the case of a bad performance by the firm or the manager. This may reduce the scope for collusion between the director and the manager. However, if allowing: for collusion is in the interest of the shareholder, this would be an argument in favor of legal resturictions on the ease with which directors can be fired. In many Furopean countries such restrictions exist. Therefore, such an analysis could shed some light on the advantages and disadvantages of the various corporate systems that we observe. In particular, it may contribute to the current discussion about the disadvantages of the alleged shareholder short-termism in the Anglo-Saxon system [e.g., Abert (1991), Miles (1993, 1995) and Satchell and Damant (1995)].

\section{Appendix}

\section{From equation $(3.3)$ to equation $(3.4)$}

For clarity we restate equation $(3.3)$ in the text:

$$
S V=x_{2}^{e}-W_{m}-c^{e}
$$

The expected firing cost depends both on the probability that the cash flow of the firm in the frst period falls below the threshold $\tau$, as well as on the expected roalization of tha fring cost given that a manager is fired. A manager is always fred if $x_{1}<r$. Hence, the expected fring cost equals $\operatorname{Pr}\left\{x_{1}<\tau\right\} \bar{C}$. Therefore, the shareholder walue can be rewtiten 
as:

$$
S V=x_{2}^{e}-W_{m}-\operatorname{Pr}\left\{x_{1}<\tau\right\} \mathbb{C}
$$

The expected cash How of the firm in the second period depends on the manager's type in that period. If the incumbent manager is retained, the expected second-period cash How is $\mu_{p}$ if he is bad and $\mu_{G}$ if he is good, respectively. If he is fired, a new manager of unknown type will be hired. He generates an expected cash flow of $\bar{\mu}$. Hence:

$$
\begin{aligned}
S V= & \operatorname{Pr}\left\{x_{1}<\tau\right\} \bar{\mu}+\operatorname{Pr}\left\{x_{1} \geq \tau\right\}\left(\operatorname{Pr}\left\{B \mid x_{1} \geq \tau\right\} \mu_{B}\right. \\
& \left.+\operatorname{Pr}\left\{G \mid x_{1} \geq \tau\right\} \mu_{G}\right\}-W_{m}-\operatorname{Pr}\left\{x_{1}<\tau\right\} \bar{C}
\end{aligned}
$$

where $B(G)$ stands for the event of the manager being bad (good).

Bayes" rule yields:

$$
\begin{aligned}
& \operatorname{Pr}\left\{x_{1}<\tau\right\}=\operatorname{Pr}\{B\} F_{B}(\tau)+\operatorname{Pr}\{G\} F_{G}(\tau), \\
& \operatorname{Pr}\left\{B \mid x_{1} \geq \tau\right\}=\frac{\operatorname{Pr}\{B\}\left\{1-F_{B}(\tau)\right]}{\operatorname{Pr}\left\{x_{2}>\tau\right\}} \\
& \operatorname{Pr}\left\{G \mid x_{1} \geq \tau\right\}=\frac{\operatorname{Pr}\{G\}\left[1-\operatorname{Fo}_{G}(\tau)\right\}}{\operatorname{Pr}\left\{x_{2} \geq \tau\right\}}
\end{aligned}
$$

where $F_{B}(\cdot)$ and $F_{G}(\cdot)$ are the distribution functions associated with $f_{B}(\cdot)$ and $f_{C}(\cdot)$, respectively. Substituting the abowe expressions into (3.A.3), we obtain:

$$
\begin{aligned}
S V= & \left(\operatorname{Pr}\{B\} F_{B}(\tau)+\operatorname{Pr}\{G\} F_{G}(\tau)\right)(\mu-\tilde{C}) \\
& +\operatorname{Pr}\{B\}\left[1-F_{B}(\tau)\right] \mu_{B}+\operatorname{Pr}\{G\}\left[1-F_{G}(\tau)\right] \mu_{G}-W_{n z}
\end{aligned}
$$

Substracting and addirg $\operatorname{Pr}\{B\} F_{B}(\tau) \mu_{B}+\operatorname{Pr}\{G\} F_{G}(\tau) \mu_{G}$, and rearranging yields:

$$
\begin{aligned}
S V= & \operatorname{Pr}\{B\} F_{B}(\tau)\left(\bar{\mu}-\mu_{B}-\bar{C}\right) \\
& +\operatorname{Pr}\{G\} F_{G}(\tau)\left(\bar{\mu}-\mu_{G}-\bar{C}\right)+\operatorname{Pr}\{B\} F_{B}(\tau) \mu_{B} \\
& +\operatorname{Pr}\{B\}\left[1-F_{B}(\tau)\right] \mu_{B}+\operatorname{Pr}\{G\} F_{G}(\tau) \mu_{G}
\end{aligned}
$$




$$
+\operatorname{Pr}\{G\}\left[1-F_{G}(\tau)\right] \mu_{G}-W_{\mathrm{m}}
$$

Because

$$
\begin{aligned}
& \operatorname{Pr}\{B\} F_{B}(\tau) \mu_{B}+\operatorname{Pr}\{B\}\left[1-F_{B}(\tau)\right] \mu_{B} \\
& +\operatorname{Pr}\{G\} F_{G}(\tau) \mu_{G}+\operatorname{Pr}\{G\}\left[1-F_{Q}(\tau)\right] \mu_{G}=\vec{\mu}
\end{aligned}
$$

we obtain, after some rearranging:

$$
\begin{aligned}
S V= & \bar{\mu}-W_{m_{0}}+\operatorname{Pr}\{B\} F_{B}(\tau)\left(\mu-\mu_{B}\right) \\
& -\operatorname{Pr}\{G\} F_{G}(\tau)\left(\mu_{G}-\bar{\mu}\right)-\operatorname{Pr}\left\{x_{1}<\tau\right\} \bar{C},
\end{aligned}
$$

which, after substituting $\Delta \mu$ for $\left(\vec{\mu}-\mu_{B}\right)$ and $\left(\mu_{G}-\bar{\mu}\right), \operatorname{Pr}\{G\}=\operatorname{Pr}\{B\}=\frac{\|}{2}$ and $\frac{1}{2}\left[F_{B}(\tau)+F_{G}(\tau)\right]$ for $\operatorname{Pr}\left\{x_{1}<\tau\right\}$, equals $(3,4)$ in the text.

\section{Derivation of equation (3.7)}

We start from equation (3.4) in the text:

$$
S V=\ddot{\mu}-W_{m}+\frac{1}{2}\left[F_{B}(\tau)-F_{G}(\tau)\right] \Delta \mu-\frac{1}{2}\left[F_{B}(\tau)+F_{O}(\tau)\right] \bar{C} .
$$

Using the details of Figure $3-1$, we have the following:

$$
\begin{aligned}
& F_{B}(\tau)=\int_{0}^{r} f_{B}\left(x_{1}\right) d x_{1}=\frac{2}{x} \tau-\frac{1}{X^{2}} \tau^{2} \\
& f_{G}(\tau)=\int_{0}^{r} f_{G}\left(x_{1}\right) d x_{1}=\frac{1}{X^{2}} \tau^{2}
\end{aligned}
$$

Substituting these results and (3.6) into (3.A.7), we get, after rearranging:

$$
S V=\pi-W_{m}+\frac{1}{4} \Delta \mu-\frac{1}{2} C\left(1-\frac{1}{2} \frac{\vec{C}}{\Delta H}\right)
$$


whic is the frest line of equation (3.7). In Section 3.4 we explain that if $\bar{C} \geq \Delta \mu$, the shareholder sets $\tau^{*}=0$, which implies that the shareholder value reduces to $\bar{\mu}-W_{r n}$, which is the areorid line of equation $(3.7)$.

\section{Proof of Lemmas 1 and 2.}

The whareholder maximizes (3.21) over a and p. Dropping terms that do not depend on $\alpha$ and $p$, wa can wite the slyreholder's problem as:

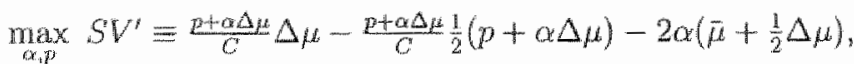

$$
\begin{aligned}
& \text { s.t. } \\
& p \leq \alpha \Delta \mu \\
& p+\alpha \Delta \mu \leq \mathrm{C} \\
& \alpha \geq \alpha_{0}=\frac{W_{a i}}{\beta+1} \Delta \bar{l}^{2} \\
& \alpha \geq 0, p \geq 0
\end{aligned}
$$

The first constraint has been discussed in the text and ensures that a good manager is never fired. The second constraint, also discussed in the text, ensures that the probability $(p+\alpha \Delta, y) / C$ does not exced one. The thind constraint is the participation constraint of the director.

Note that

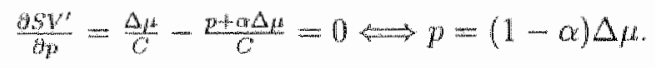

$$
\text { Case } l(\Delta \mu>C)
$$

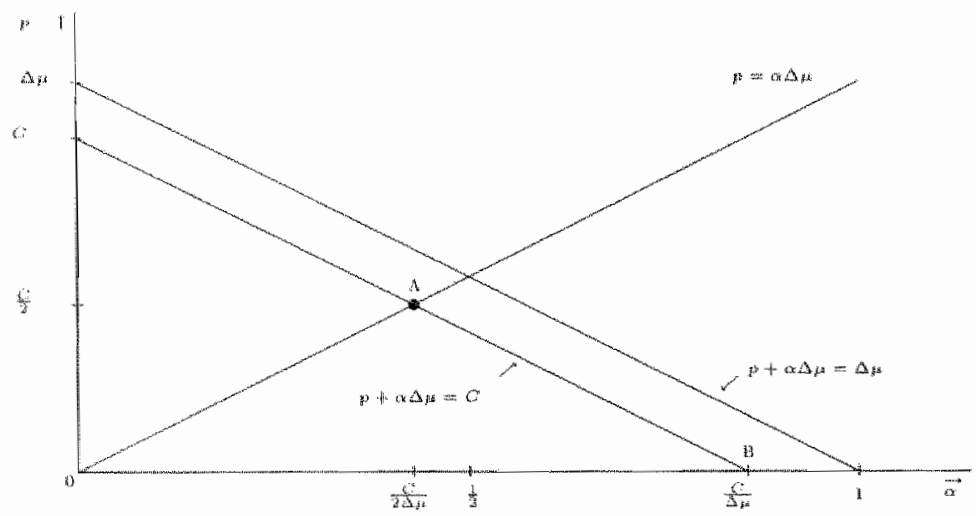


For the moment, ignore the constraint $\alpha \geq a^{0}$. The admissible area is the triangle $O A B$. For a given $\alpha, S V^{\prime}$ is a quadratic function of $p$, which reaches its maximum for $p=(1-\alpha) \Delta \mu$ (see (3.A.9)). Hence, the optimum must be located on OA or AB. Suppose that it is located on $A B$. Then, $p+\alpha \Delta \mu=C$. This can be substituted into the objective function, which reduces to $S V^{\prime}=\Delta \mu-\frac{1}{2} C-2 \alpha\left(\bar{\mu}+\frac{1}{2} \Delta \mu\right)$. Hence, $\alpha$ should be chosen as low as possible. Hence, if the optimum is located on $A B$, it must be at $A$. But this implies that it is located on $\mathrm{OA}$. Hence, $p=\alpha \Delta \mu$. Substitute this into the objective function to eliminate $p$. Maximize the resulting function with respect to $\alpha$ and apply the restriction that $0 \leq \alpha \leq C /(2 \Delta \mu)$ (to ensure that the optimum is located on the line piece $O A$ ). If we use in addition that $\vec{\mu}+\frac{1}{2} \Delta \mu=\frac{7}{2} \Delta \mu$ (see Figure 3-1), we obtain:

$$
\tilde{\alpha}=\max \left[0, \min \left(\frac{2 \Delta_{\mu-7}-7 C}{4 \Delta_{\mu}}, \frac{C}{2 \Delta_{\mu}}\right)\right]
$$

Finally, apply the constraint $\alpha \geq \alpha^{0}$, which we have neglected so far. Because $\alpha^{0} \leq$ $C / \triangle \mu$, as follows from $(3.8)$, we have:

$$
\begin{aligned}
& \text { If } \tilde{\alpha} \leq \alpha^{0}, \text { then } \alpha^{*}=\alpha^{0} \text { and } p^{*}= \begin{cases}\alpha^{0} \Delta \mu & \text { if } \alpha^{0} \leq \frac{C}{2 \Delta \mu}, \\
C-\alpha^{0} \Delta \mu, & \text { if } \frac{C}{2 \Delta \mu}<\alpha^{0} \leq \frac{G}{\Delta \mu}\end{cases} \\
& \text { If } \tilde{\alpha}>\alpha^{0}, \text { then } \alpha^{*}=\tilde{\alpha} \text { and } p^{*}=\tilde{\alpha} \Delta \mu .
\end{aligned}
$$

Case $2(\Delta \mu \leq C)$

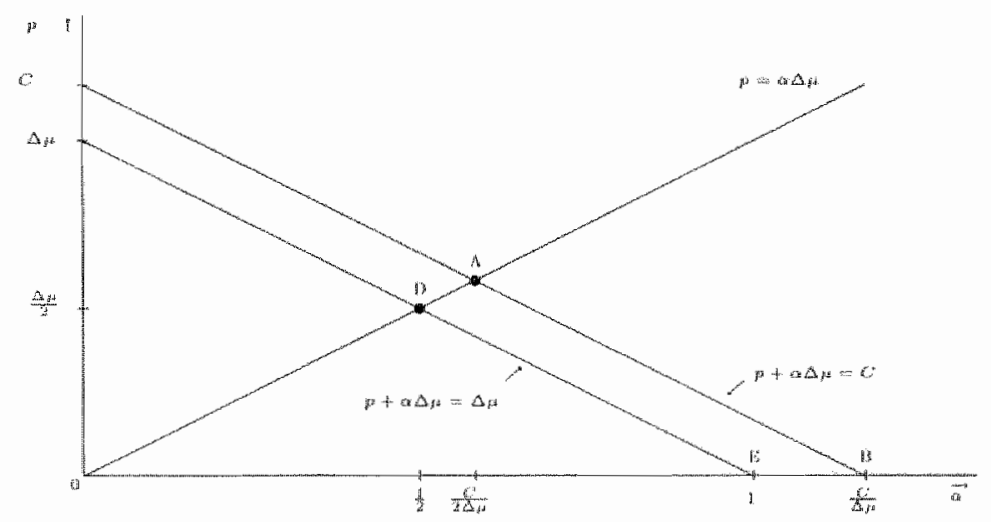

In this case, OAB is again the admissable area, and by (3.A.9) the optimal solution 
must be located on $\mathrm{OD}$ or on $\mathrm{DE}$. As before, if the solution lies on $\mathrm{DE}$, it must be located at D. Going through similar steps as in Case 1, we obtain:

$$
\tilde{x}=\max \left[0, \min \left(\frac{2 \Delta Q x-70}{4 \Delta_{x}}, \frac{1}{2}\right)\right]=0
$$

Applying that $a \geq a^{0}$ yields the solution

$$
\alpha^{*}=\alpha^{0} \text { and } p^{*}= \begin{cases}\alpha^{0} \Delta \mu, & \text { if } \alpha^{0} \leq \frac{1}{2} \\ \left(1-\alpha^{0}\right) \Delta \mu, & \text { if } \frac{1}{2} \leq \alpha^{0} \leq 1\end{cases}
$$




\section{Chapter 4}

\section{Incentive Signalling and Bankruptcy}

\subsection{Introduction}

In their seminal paper, Modigliani and Miller (1958) show that in perfect capital markets the market value of any firm is independent of its capital structure. ${ }^{1}$ The basic idea behind this proposition is that the market value of a firm is determined by capitalizing the expected profit stream of the assets. Changing the way in which these expected profits are distributed between shareholders and debtholders should not alter the value of the firm.

An important line of follow-up papers considers the tax advantage of corporate debt, an issue that Modigliani and Miller (1963) discussed themselves as well. Interest expenses are deductible, so by issuing debt firms can recuce their tax bill and increase their market. value. As a consequence of this theory, firms should be leveraged 100\%! However, other theories have stressed the fact that increased leverage also means an increased risk of getting into financial distress. This, in turn, implies an increased risk of incurring bankruptcy costs, both direct (e.g., fees for lawyers) as well as indirect (e.g., lloss in reputation). Compromising theories explain an optimal capital structure as a trade-off between these tax advantages and bankruptcy costs. ${ }^{2}$

Subsequently a second important line of follow-up papers developed, which was inspired by the development of agency theory. Agency theory focuses on the possible conflict

\footnotetext{
"By capital structure, mean the proportion of equity and debt.

2For example: Kratus and Litzenberger (1973), Scott (1976) and Kin (1978).
} 
of interest between management and the different claimholders of the firm. Two major approaches can be distinguished. The first concentrates on the moral hazard aspect of the agency relation, and its discussion was initiated by the pathbreaking paper of Jensen and Meckling (1976) "In their paper, they give many examples of how management can take actions which are bad for the clamholders, and of how the claimholders will anticipate this bohavior.

The sccond approach focuses on the adverse selection aspect of the agency relation, following a well-known paper by Akerlof (1970). In this paper, Akerlof shows how asym metric information may prevent a transaction between two agents, even if this transaction is profitable for both agents ("market breakdown'). Signalling can mitigate this adverse selection problem." The incentive-signaling approach of Ross (1977), upon which the model in this chapter is based, should be placed in this last category of information asymmetry. ${ }^{5,6}$

Ross considers a world in which managers have private information about the true value of their firm. This gives rise to adverse selection problems. If investors do not get additional inlomation, the value of the firm as inferred by the market will be a weighted average of the values of all the firms. In other words, if they buy a (share of the) firm, they incur the risk of investing in (adversely selecting) a bad one, i.e., one of low walue.

A management compensation scheme is designed to give the managers of the firms an incentive to signal to the market the true value of their firm. By increasing the debt lovel, managers con increase the value of their firm as percened by the market. Because their componsation is proportional to this penceived value, they will have an incentive to mise their debt, level to some maximum. However, managers will incur a personal penalty

\footnotetext{
inother innportant paper is Myers (1977), who focuses on the moral hazard aspects of corporate borrowing. More recent contributions in this area explore the possible interactions between financial and product market decisions, eg. Tituan (1984), Brander and Lewis (1986), Maksimovic (1988), and Muksimowic and Titman (1991).

"The term "signalling" and its basic properties were introduced into the economic literature by spence $(1973)$.

"Two other important signalling papers are Bhattacharya (1979) and Leland and $P$ yle (1977). The former usw cash dividends that are taxed at a higher rate than capial gains as a signal, the latter the wisystematic risk bome by the entrepreneurs who hold a fraction of their own project or firm.

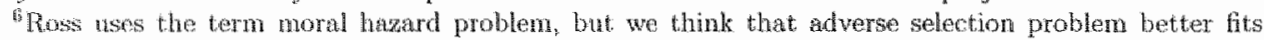
this particular setting. Cools (1993) refers to cnoral hazard in situations where both parties are equally informed at the time of the contract and where only after the contract one of the parties obtains superior intomation. Adverse selection then refers to situations where the parties are unequally informed prior to the contract being drawn up.
} 
when the firm goes bankrupt. Hence, by increasing the debt level, each manager faces a trade-off between an increased value of the firm and an increased expected penalty. In the equilibrium that Ross was looking for, managers will, as a consecuence of this trade off, distinguish themselves by choosing the debt level in such a way that the debt level increases with the true value of their firm. The adverse selection problem, then, is resolved.

The same result could have been obtained if managers of good fims simply assert a liability of the size of the penalty if the cash flow falls below a certain threshold. According to Ross, however, using debt has the advantage that it is an instrument which is priced in the market. Hence, implicit in the argument is that it is cheaper to monitor if a firm goes bankrupt or not than monitoring an ad hoc assertion of liability.

This chapter makes two contributions. Firstly, we take the line of reasoning of the preceding paragraph one step further. If debt has the advantage that it is a market device, then the next logical step is to allow for a penalty system which is determined by the market as well. Since it is bankruptcy that triggers the penalty to be paid, we use the (market determined) bankruptcy costs as the penalty system. Managers are compensated in proportion to the value of their firm and, therefore, still face a trade-off between a higher value of their firm as perceived by the market in the first period, and a lower expected value of the firm in the second period due to the bankruptcy costs.

Secondly, we formalize Ross's incentive-signalling approach by using game-thoretic concepts that were subsequently developed after his paper. More specifically, we obtain a unique separating equilibrium by using the intuitive eriterion of Cho and Kreps (1987). In such an equilibrium, the manager of the bad firm chooses a debt level of zero, and he is recognized by the market as being bad. The manager of the good fin is recogrized by the market as being good by choosing a debt level that is sufficiently hight to discourage the manager of the bad firm to imitate him. However, we show that this unique equilintium, which is similar to Ross's unique competitive (separating) equilibrium, can only survive if the bankruptcy costs are sufficiently high. Otherwise, only pooling equilibria exist, in which both the bad and the good manager chose the same debt level, such that the market cannot distinguish between the two managers.

One of the most important aspects of debt is the possibility to take over control from 
the incumbent management in case of a defaut. In Harris and Raviv (1990), managers are reluctant to hquidate the firm under any circumstances and are umwilling to provide detailed information to investors that could result in such an outcome. Continuously monitoring the firm would be very costly for the investors. Therefore, debt is used to discipline management, much in the spirit of the free cash flow theory [Jensen (1986)]. "The mere repayment of the debt obligations provides information about the firm's prospects. In case of bankruptey, investors are willing to pay the bankruptcy costs in order to generate information that is useful for an optimal liquidation decision. Hence, in Harris and Raviv (1990), bankruptcy costs can be seen as the necessary agency costs to relieve problems of moral hazard.

Note that for the signalling mechanism to work in our model, the firm has to be forced into bankuptcy in the cass of default. If managers would anticipate an informal reorganization (workout) insteac of a formal bankruptcy in some states of the world, the expected bankruptcy costs would cliange. This, in turn, would change the incentives of raising debt and, hence, the equilibria as well. Therefore, in our model, the bankaruptcy costs can be seen as the necessary agency costs to relieve problems of adwerse selection.

The remainder of this chapter is structured as follows. Section 4.2 presents the basic model, introducing the players, the actions, and the payoff functions. Moreover, it provides a short, intuitive introduction to signalling games. In Section 4.3 we analyze the Perfect Bayesian Equilibria of the gane. We show that multiple equilibria exist, both separating (Section 4.3.1) as well as pooling (Section 4.3.2). In Section 4.4 we introduce a stronger equilibrium concept, the intutive ctiterion of Cho and Kreps (1987), to end up with a mique equilibrium. ${ }^{7}$ Section 4.5 concludes, and briefly discusses the connection with the workout literature in bankruptoy.

\subsection{The Basic Model}

Signalling games belong to the broader subclass of dynamic games of incomplete informalion. A signalling game involwes two players. One of the players has private information,

\footnotetext{
"For an elementary introduction to signalling games, Perfect Bayesian Equilibria, and the intuitive miterion, see Cibbons (1992).
} 
the other is uninformed about this information. The informed player sends a signal aud the uninformed player then chooses a response to this signal. A basic feature of a signalling game is that the sender has different types $\left(t_{i} \in T\right)$, which reflects the private information of the sender. Typically, a distinction is made between "good' types and 'bad' types. The key idea is that communication occurs if the good type of the informed player is willing to send a signal that is too expensive for the bad type to imitate.

We consider a two-period model with two types of firms, good firms $(G)$ and bad firms $(B) .8$ Their cash flows in period 1 are uniformly distributed on the interval $[0, G]$ and $[0, B]$, respectively, with $B<G$. Investors only have an a priori belief about the distribution of these firms, whereas managers know the true value of their firm. As long as investors do not receive additional information, the value of the firm as inferred by the market will be a weighted average of the values of all the firms. This adverse selection problem will be resolved if the managers can be induced to signal to the market the true valne of their firm. We will, much in the spirit of Ross, explore how to design a managerial compensation scheme that accomplishes this.

The main idea is as follows. Managers can signal the value of their firm by issuing debt, with face value $F$. We assume that the capital structure of the firm does not alter its investment opportunities. Managers are compensated in proportion to the value of their firm. If the firm goes bankrupt it will incur bankruptcy costs $C$ and, hence, the compensation of the manager will decrease proportionally. Hence, by issuing dobt, all managers face a trade off between a higher percetwed value of their frm in the first period $\left(V_{0}(F)\right)$, and an increased risk of going bankrupt and a lower true value of their fim in the second period $\left(V_{1}\left(F^{\prime}\right)\right.$ ). However, because a good firm has a lower risk of going bunkrupt, given the face value of the debt, its manager has a stronger incentive to issue debt. In (a separating) equilibrium, each manager issues debt in proportion to the true wahne of their firm and the market will correctly deduce the type of firm from the signal it receives."

To complete the description of the game, we make the following assumptions:

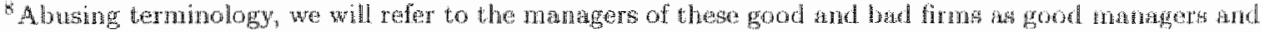
bad managers, resinectively

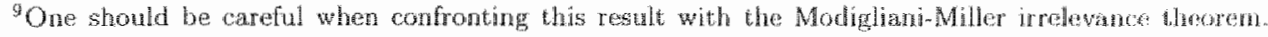
In on model capital structure not only influences the true walue of the firm bexase of the expected

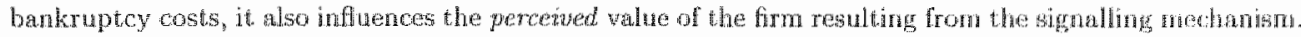


Assumption $\mathbb{1}$ "The mandgers" incentive compensation schedule is common knowledge.

The incentive scheduc (payof function) for the manager is given by:

$$
S=\gamma_{0} V_{0}(F)+\gamma_{1} V_{1}(F)
$$

where $\gamma_{0}$ and $\gamma_{1}$ are fxed non-negative weights. In other words, the manager receives a fraction $\gamma_{0}$ of the perceived value of the firm in the first period, and a fraction $\gamma_{1}$ of the true walue of the firm in the second period. As we will see below, this will result in the previously discussed trade-off of raising debt $(F)$.

Assumption 2 A firm will always be declared bankrupt when it cannot meet its debt olligations.

Hence, we exclude the possibility of an informal reorganization. This allows us to highlight the factors which determine whether the unique equilibrium that survives is pooling or separating. In Section 4.5 , we will briefly describe the consequences of allowing for an informal reorganization in some states of the world.

Assumption 3 Managers cannot trade in the financial instruments issued by their own finm.

Relaxing this assumption would change the nature of the incentive schedule as indicated in (4.1). In most countries, managers are prohibited by law from trading in tho Thancial instruments of their own firm, especially around event dates, i.e, at. moments whon adwerse selection problems due to asymmetric information can be severe.

Assumption 4 Financial makets are competitive and perfect (i.e, there are no transaction costs or tax effects). Moreover, all agents are risk-neutral and the interest rate is zero.

These are commonly rnade assumptions which help us to highlight more clearly the basic intuitions behind the model. The payoff function for the market is as follows:

$$
R=-\left[V_{0}(F)-V_{1}(F)\right]^{2}
$$


In other words, the payoff is highest when the perceived value is equal to the true value. ${ }^{10}$

The game is represented graphically in Figure 4-1. It starts with a moxe of nature $(N)$, which draws one of two possible types of firms: a good firm $(G)$ with probability $\theta$ and a bad firm $(B)$ with probability $(1-\theta)$. The manager then signals the value of his firm by choosing a debt level $F$, where $F \in[0, G] . "$ Note that, given a debt level $F$, the true value of a good firm is $\frac{G}{2}-\frac{F C}{G}$, which is simply the expected cash flow minus the expected bankruptcy costs. Mutatis mutandis, the true value of a bad firm is $\frac{B}{2}-\frac{F C}{B}$. The receiver, in our model the market $(M)$, does not know whether the signal was from a good or a bad firm. This is represented by the vertical broken line between two nodes of the same signal, and such a pair of nodes is called an information set. ${ }^{12}$ At such an information set, the market has belief $p$ that the firm that sent the signal is good, and $(1-p)$ that it is bad. ${ }^{13}$

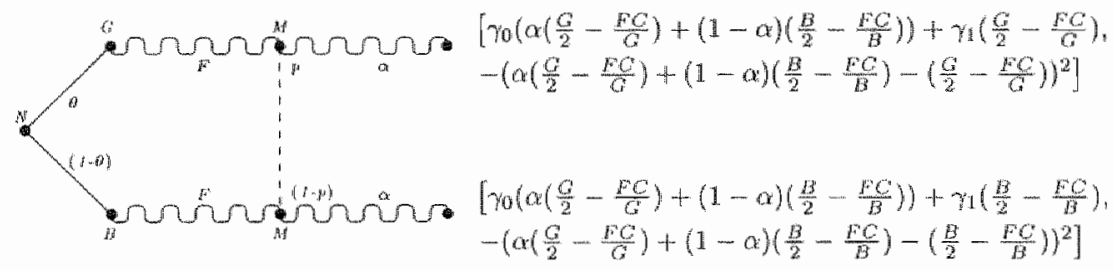

Figure 4-1: Extensive form representation of the signalling game.

The action of the market is to value the firm somewhere between $\frac{G}{2}-\frac{E C}{G}$ and $\frac{H A C}{2}-\frac{F C}{15}$, using as a weight $\alpha$, where $\alpha \in[0,1]$. Hence, $\alpha$ can be interpreted as the mique factor that. determines the price the market is prepared to pay for the firm. At the terminal nodes the payoffs of both players are indicated between square brackets, the first for the manager of the firm and the second for the market. if These payoffs are based upon equations (4.1) and (4.2), respectively.

\footnotetext{
${ }^{16}$ As we will see at the end of this section, this specification ensures that the merthet walues the firm according to its beliefs, which is in line with the competitive character of the market.

${ }^{1}$ The undulating line indicates that any debt lewel within the given boundaries is possible. A debt level greater than $G$ could never function a credible signal, because even at gool firm would never be able to repay this debt completely.

12 Note that there as many information sets as there are possible values for $F$.

${ }_{13}$ For further explanation of the beliefs $p$ at the decision nodes for the receiver, we refer to section 4 s.

1. Note that there are as many terminal nodes as there are possible combinations of $(t, F, c)$.
} 
The payoff function for the maxket is constructed such that it represents a perfect and competitive market. "This means that investing in a firm must have a zero net present value. In Section 4.3 (Lemma 1) we will see that the optimal action of the market is to walue the firm according to its beliefs. If an investor values the firm different from his belick, then either he pays too much $(\alpha>p)$ or his offer is insufficient $(\alpha<p)$, resulting in an opportunity loss because another investor will buy the firm at $(\alpha=p)^{15}$

\subsection{Perfect Bayesian Equilibria}

In this section we detemine the Perfect Bayesian Equilibria (PBE) of the game. ${ }^{16}, 17$ Such an equilibrium satisfies the following conditions.

Signalling Requirement 1 After observing a message $F$, the receiver must have a belief about which types could have sent $F$. Formally, we denote the receiver's belief that the sender is of type $t_{i}$, given the signal $F$, by the probability distribution $p\left(t_{i} \mid F\right)$, where $p\left(t_{i} \mid F\right) \geq 0$ vor each $t_{i}$, and $\sum_{t_{\mathrm{i}}}\left(p\left(t_{i} \mid F\right)\right)=1$.

Signalling Requirement $2 \mathrm{r}$ For each $F$, the receiver's action $\alpha^{*}(F)$ must maximize his expected payof, given its beliefs $p\left(t_{i} \mid F\right)$ about which types could have sent $F$. That is, $\alpha^{*}(F)$ solves

$$
\max \alpha \sum_{i_{i}} p\left(t_{i} \mid F^{2}\right) U_{v}\left(t_{i}, F, \alpha\right)
$$

where $U,(\cdot)$ is the receiver"s pelyoft.

Signalling Requirement 2 s For each $t_{i}$ in $T$, the sender's message $F^{*}\left(t_{i}\right)$ must maximize the sender's expected payoff, given the receiver's strategy $\alpha^{*}\left(F^{*}\right)$. That is, $F^{*}\left(t_{i}\right)$

\footnotetext{
Th The for that the optimal action of the receiver will whys be to value the firm according to its betief mpreses the wherlyng competive process on the capital market. One could, for example, fissune a forth of Bertand competion between risk-neutal investors, where profits are driven to wero. If a firm Ins to fin mo itsell on a non competitive market (e.g. in a barganing process with a limited number of banks), then or may depend on other factors than the beliefs, such as the relative barganing powar of the differemit purties.

Much of the forma! notation in this and the following section is drawn from Gibbons (1992).

Note that, bochnse wave cignalling game with discrete types, every PBE is also a secuential equilibring fsec Corollary 5 . Perea y Monsuwe et al. (1997)].
} 
solves

$$
\max _{F} U_{s}\left(t_{i}, F, a^{*}(F)\right)
$$

where $U_{s}(\cdot)$ is the sender's payoff.

Finally, let $T_{j}$ denote the set of types that, in equilibrium, send the message $F_{j}, \mathrm{i} . \mathrm{e}, \mathrm{t}$, is a member of the set $T_{j}$ if $F^{*}\left(t_{i}\right)=F_{j}$.

Signalling Requirement 3 For each $F_{y}$, if there exists a $t_{i}$ in $T$ such that $F^{*}\left(t_{i}\right)=F_{3}$, then the receiver's belief at the information set corresponding to $F_{j}$ must follow from Bayes' rule and the sender's strategy:

$$
p\left(t_{i} \mid F_{j}\right)=\frac{p\left(t_{i}\right)}{\sum_{t_{i} \in T_{j}}\left(p\left(t_{i}\right)\right)} .
$$

where $p\left(t_{i}\right)$ is the unconditional belief of the receiver that the sender is of type $t_{i}$.

Definition A Perfect Bayesian Equilibrium in a signalling game is a pair of strategies and beliefs satisfying Signalling Requirements $1,2 \mathrm{r}, 2 \mathrm{~s}$ and 3 .

We can now tum to Lemma 1 as discussed at the end of Section 4.2.

Lemma 1 The optimal action of the recenver will always be to value the firm according to its beliefs, i.e., $\alpha=p$.

Proof The expected payoff for the receiver who received signal $F$, given beliefs $p$, is: ${ }^{18}$

$$
\begin{aligned}
E\left[U_{r}\right]= & p\left[-\left(\alpha\left(\frac{G}{2}-\frac{F G}{Q}\right)+(1-\alpha)\left(\frac{B}{2}-\frac{F C}{B}\right)-\left(\frac{C}{2}-\frac{F C}{G}\right)\right)^{2}\right] \\
& +(1-p)\left[-\left(\alpha\left(\frac{G}{2}-\frac{F C}{G}\right)+(1-\alpha)\left(\frac{B}{2}-\frac{F C}{B}\right)-\left(\frac{B}{2}-\frac{F C}{B}\right)\right)^{2}\right], \\
= & -p\left[\alpha\left(\left(\frac{G}{2}-\frac{F C}{G}\right)-\left(\frac{B}{2}-\frac{F C}{B}\right)\right)-\left(\left(\frac{G}{2}-\frac{F C}{G}\right)-\left(\frac{B}{2}-\frac{F C}{B}\right)\right)\right]^{2} \\
& -(\mathbb{1}-p)\left[\alpha\left(\left(\frac{C}{2}-\frac{F C}{G}\right)-\left(\frac{B}{2}-\frac{F C}{B}\right)\right)\right]^{2}, \\
= & -p\left[\left(\left(\frac{C}{2}-\frac{F C}{Q}\right)-\left(\frac{B}{2}-\frac{F C}{B}\right)\right)^{2}-2 \alpha\left(\left(\frac{G}{2}-\frac{F C}{Q}\right)-\left(\frac{B Q}{2}-\frac{F C}{B}\right)\right)^{2}\right] \\
& -\alpha^{2}\left[\left(\frac{G}{2}-\frac{F C}{G}\right)-\left(\frac{B}{2}-\frac{F C}{B}\right)\right]^{2} .
\end{aligned}
$$

\footnotetext{
${ }^{16}$ Note that the beliefs depend on the signal $F$. However, for ease of notation, we will writo $p$ ingtend of $p(F)$ throughout the paper.
} 
Using the firstorder condition with respect to $a$, we have

$$
2 p\left[\left(\frac{B}{2}-\frac{F C}{G}\right)-\left(\frac{B}{2}-\frac{F C}{E}\right)\right]^{2}-2 Q\left[\left(\frac{G}{2}-\frac{F C}{G}\right)-\left(\frac{B}{2}-\frac{P^{2} C}{B}\right)\right]^{2}=0
$$

which is obviousty satisfied for:

$$
a=p
$$

This completes the proof that it is always optimal for the receiver (the market) to value the firm actording to its beliefs, expressing the underlying competitive process on the capital market. Hence, setting $\alpha=p$ satisfies Signalling Requirement $2 \mathrm{r}$. For the remander of the chapter the reader should bear in mind that equation (4.6) always holds in equilibrium.

In the game described in Figure 4-1, we have two types and, hence, we can distinguish between two possible equilibria:

- Separating equilibrium (Section 4.3.1).

- Pooling equilibrium (Section 4.3.2).

\subsubsection{Separating Equilibrium}

In in separating equilibrim, both types signal the value of then firm by issung a difterent anonit of debt. Wo denote the equilibrium debt levels for good and bad frms by $F_{C}$ and $F_{i 3}^{*}$ rospectivaly. According to Signalling Requirement, 3 , the receiver must have a belief, consistent with Bayes' nule, about the type that sent the message. Hence, if such w equibrim exists, then the market believes that a firm is of type $G$ after receiving a signal $F_{C}^{*}(i, e, p=1)$ and believes that a firm is of type $B$ after receiving a signal $F_{B}$ $(a, p=0)$. For other signals $F$, the belief $p$ can be freely chosen.

Berore we describe the sustainable separating equilibria in Lemma 2, we note that these equilibria can only hold with $F_{B}=0$, because otherwise the manager of a bad firm will always have an incentive to deviate. The proof goes by contradiction. If a bad manager signals his oquilibrium value $F_{i}^{*}>0$, the market will value him as a bad firm. If he deviates 
to signalling $F_{B}^{*}=0$, then the worst thing that can happen is that his firm is still walued as a bad firm, but at least he would not incur the expected value of the bankruptcy costs.

Lemma 2 Given an appropriate set of beliefs, there exist multiple separating Perfect Bayesian Equilibria of the form $\left(F_{G}^{*}, 0\right),(\alpha=p)$. The bold line in Figure $4-2$ shous that all possible equilibrium values for $F_{G}^{*}$ are located on the interval $\left[F_{G, \text {,nim }}^{*}, F_{G, \text { max }}^{*}\right]$. These values area calculated in the indicated equation numbers. A last condition for such an equilibrinm to hold is $F_{G}^{*} \leq G$.

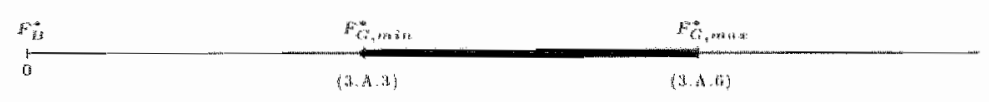

Figure 4-2: Possible values for $F_{G}^{*}$ in a separating PBE.

\section{Proof See the Appendix.}

The intuition for Lemma 2 is as follows. A bad manager will not have the incentive to imitate a good manager if the latter chooses a signal $F_{G}^{*} \geq F_{G, \text { min }}^{*}$, because the increase in expected bankruptcy costs in the second period would be greater than or equal to the increase in his compensation in the first period due to the higher valuation of the firm by the market. The good manager will not have the incentive to imatate the bad manager if $F_{G}^{*}$ does not exceed $F_{G_{3}}^{*}$ max , because the gain from issuing less delbt and, hence, incurring less expected bankruptcy costs would be lower than or equal to the decrease in salary due the lower valuation of the firm by the market. Moreover, deviations off the equilibrium path will not be profitable for both managers if we impose $p=0$ in those cases.

This is the equilibrium that Ross (1977) implicitly focussed on. The manager of the good firm can afford to signal $F_{G}^{*}$ to the market to distinguish himself as being good. The manager of the bad firm does not have an incentive to give a false signal, because the expected value of the penality he incurs is too high.

We will now characterize the set of pooling equilibria of the game, an issue that Ross was not able to take up due to lack of formalization of his model. 


\subsubsection{Pooling Equilibrium}

In a poling equilibrium, both types signal the value of their firm with the same debt level $\left(F^{7}\right)$. The belief of the market that the firm is good, consistent with Bayes rule, after this signal $F^{*}$ is $\theta$. Following oun discussion in Section 4.2 , this implies that a firm signalling $F^{*}$ will be walued at $\theta\left(\frac{C}{2}-\frac{F^{*} C}{G}\right)+(1-\theta)\left(\frac{B}{2}-\frac{F^{*} C}{E^{*}}\right)$. Whether such an equilibrium can sustain or not critically depends on the belief $p$ of the receiver if a manager deviates. Because a deviation will always be off the equilibrim path, this belief can be freely chosen.

Lemma 3 Giten an appropriate set of beliefs, there exist multiple pooling Perfect Bayesian Equalibria of the form $\left(F^{*}, F^{*}\right),(\alpha=p)$. The bold line in Figure $4-3$ shows that all possible values for $F^{*}$ are lacated on the interval $\left[0, F_{\max }^{*}\right]$. The value for $F_{\max }^{*}$ is calculated in the indicated equation nunber. A last condition for such an equitibrium to hold is $F^{*} \leq G$.

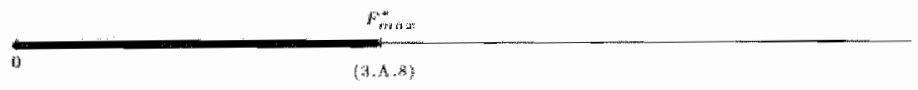

Figure 4-3: Possible values for $F^{*}$ in a pooling PBE.

\section{Proof See the Appendix.}

The intuition for Lemma 3 is straight forward. If $F^{*} \leq F_{\text {max }}^{*}$, neither manager will have tho incentive to deviate with $F<F$ by imposing $p=0$, because the loss in period 1 due to a lower valuation of the firm would be greater than or equal to the decrease in expected bankuptcy costs in period 2 . In contrast, if $F^{*}>F_{\text {max }}^{*}$, the manager of the bad firm would have the incentive to deviate to $F=0$, even if the market, will value him as bad $(p=0)$. Finally, by imposing $p=0$, neither manager will have the incentive to deviate to $F^{*}>F^{*}$, because this would result both in a lower waluation of the firm in period 1, and higher expected bankruptcy costs in period 2 .

\subsection{The Intuitive Criterion}

In Section 4.3 we have seen that the concept of a Perfect Bayesian Equilibrium is not strong enough to end up with a unique equilibrium. Given an appropriate set of behefs, 
there are many separating and pooling equilibria that survive. In order to exclude the urreasonable equilibria, game theorists have come up with stronger equilibrim concepts, putting stronger restrictions on the strategies and the belids of the players. ${ }^{19}$

In this section we apply the 'intuitive criterion' of Cho and Kreps (1987) to our game. This leads to a unque equilibrium, with one restriction on the size of the bankruptcy costs. Before we can tum to the defintion of a PBE that survives this intuitive criterion, we have to define the notion of a message which is equilibrium-dominated.

Definition Given a PBE in a signalling game, the message $F$ is equilibrium-dominated for type $t_{i} \in T$ if $t_{i}$ 's equilibrium payof, denoted $U_{s}^{*}\left(t_{i}\right)$, is higher than $t_{i}$ 's highest possible payoff from $F$. Formally: $U_{s}^{*}\left(t_{i}\right)>\max a U_{s}\left(t_{i}, F, \alpha\right)$.

Definition A Perfect Bayesian Equilibrium survives the intuitive criterion if the following condition is satisfied: If the information set following $F_{j}$ is of the equilibrium path and $f_{j}$ is equilibrium-dominated for type $t_{i}$, then the belief $p\left(t_{i} \mid F_{j}\right)$ should be zero, provided that this is possible, which is the case if $F_{j}$ is not equilibrium-dominated for all types in $T$.

If $F_{j}$ is equilibrium-dominated for all types in $T$, then the beliefs can again be freely chosen, for setting them all to zero would violate Signalling Requirement 1 . Hence, the equilibria that survive the intuitive criterion form a subset of the Perfect Bayesian Equilibria. The following lemma shows how this intuitive criterion works ont for our game.

Lemma 4 Imposing the intwitive criterion on the PBE,

1. if $\mathrm{C}^{*} \mathrm{C}^{*}$, there are no pooking equilibria that survive. If $\mathrm{C} \leq \mathrm{C}^{*}$, there are mutiple pooling equitibria that survive.

2. if $C \geq C^{*}$, of all the separating equitionia, onty $F_{G \text {, nim }}$ survives. If $C<C^{4}$, there are no separating equilbria that survive.

Here,

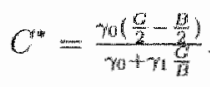

\footnotetext{
${ }_{15}$ For a short and inthitive introduction on this dewelopment in game cheory, applied to finance, see Thathor (1991).
} 


\section{Proof See the Appendix.}

The intuition for Lemma 4 is as follows. We start with the pooling equilibria (Lenma 4-1). Given a pooling equilibrium with $F^{*}$, we can always find an $\tilde{F}^{*}>F^{*}$ which is equilibrium-dominated for the manager of the bad firm and not for the manager of the good firm. The reason for this is that the expected bankruptcy costs for the bad firm increase faster than for the good firm. Hence, after a deviation to $\tilde{F}$ (or more precisely, to $F+\varepsilon$, where $\varepsilon$ is arbitrarily small), the intuitive criterion imposes belief $p=1$. It turns out that, if $C>C^{*}$, this deviation is both feasible, i.e., smaller than or equal to $G$, and profitable for the manager of the good firm. A pooling equilibrium can therefore not survive the intuitive criterion. However, if $C \leq C^{*}$, the deviation $\vec{F}$ is not feasible for some pooling equilibria (typically for the highest $F^{*}$ ), and multiple pooling equilibria survive.

For the separating equilibrium (Lemma 4-2) note that, by definition, all values of $F>$ $F_{G, \text { rin }}$ are equilibrium-dominated for the bad firm (see the first paragraph following Lemma 2). Therefore, a separating equilibrium with $F_{G}^{*}>F_{G \text {,rin }}^{*}$ can never survive, because the manager of the good firm could always deviate to $F_{G, \text { min }}^{*}$ (or more precisely $F_{G, \min }^{*}+\varepsilon$ ), holding constant his period 1 value as perceived by the market and lowering his expected bankruptcy costs in period 2. We have $F_{G, \text { anisi }}^{*} \leq G$ if and only if $C \geq C^{*}$.

Hence, applying the intuitive criterion to our game leaves us with a unique separating equilibrium, a result that, was already indicated by Thator (1991). However, Thakor dir not formally specify the whole game, because the only purpose of his paper was to demonstrate 1.he diflerent equitibriun concepts that have been developed in game theory. By formalizing the game we were able to derive the exact conditions under which this equilibrium holds. More sperifically, our andlysis shows that this result critically depends on the value of the bankuptcy costs, i.e, $C$ should be strictly greater than $C^{*}$.

This condition on the bankruptcy costs is perfectly intuitive. As we mentioned in the beginning of Section 4.2 , a key idea of signalling games is that communication can occur if one bype of the informed player is willing to send a signal that would be too expensive for another type to send. In our model a signal is expensive because of expected bankruptcy costs. These bankruptcy costs should therefore be sufficiently high to make a separating equilibrium, and thus communication, feasible. 


\subsection{Concluding Remarks}

In this chapter we have devaped and analyzed a signalling game in which managers can signal the value of their firm, which is private information to them, by choosing the debt level of the firm. If managers are compensated in proportion to the walue of their firm, and if there are positive bankruptcy costs, then managers of good frms will have an incentive to signal the higher value of their frm by choosing a higher debt level than the managers of a bad firm. The reason is that managers of good firms have a lower risk of going benkrupt and incurring part of the bankruptcy costs.

We have explored the Perfect Bayesian Equilibria of the game which satisfy the intuitive criterion of Cho and Kreps (1987). This concept leads us to the economically intuitive prediction that managers of good frms can only distinguish themselves from bad firms by means of their debt level as long as it is too expensive for the bad firms, in terms of expected bankmptcy costs, to imitate the good ones.

It is important to note that we assume that managenent anticipates a formal bankruptcy in case of a deloult. Haugen and Senbet (1978, 1988) claim that bankruptcy costs are irrelevant. to the optimal capital structure and the liquication decision, because any inefficiency due to unnecessary bankruptcy costs would be arbitraged away in an efficient capital market. In other words, given the a priori beliefs about tho distribution of good and bad frms that enter into a defaut, creditors can calculate the expected value of their claims both wader an informal reorganization (workout) and under a bankruptey. If the former value is higher, a firm will not be declared bankrupt.

However, allowing for the possibility of an informal reorganization implies, celteris paribus, that the expected bankruptey costis decrease. Our model then indicates that this may infuence the signalling equilibrium. But this, in turn, would infuence the a priori belies about the distribution of firms that enter into defaul. And this, in tum, may have an impact on the probability of a successful workout. Future research can address the interesting relation between our modal and this workout literature. ${ }^{20}$

\footnotetext{
26) For this wontont literature see, for example, Giamarino (1989), Gertner and Scharfstein (199), and Franks and Torous (1994).
} 


\section{Appendix}

\section{Proof of Lemma 2}

To show the existerice of this set of equilibria, we need to check whether Signalling Tequirements $2 \mathrm{r}$ and $2 \mathrm{~s}$ are satisfied. Since Lemma 1 shows that Signalling Requirement $2 \mathrm{r}$ is satished, we continue with Signalling Regurement 2 s. We have to check that neither type can improve by giving a different signal. When we calculate the payoff of a type from deviating, we huve to make a distinction between a deviation to the equilibrimm signal of the other type and a deviation to a signal that would never occur in equilibrium. In the former case the beliefs $p$ are detemined as follows: $p=1$ if a bad type deviates to $F=F_{C}^{*}$ and $p=0$ if a good type deviates to $F=F_{B}^{*}=0$. Tn the latter case, Signalling Requirement 3 imposes no further restrictions on the beliefs.

Wo start by checking possible deviations for the bad firm. If the bad firm signals its equilibrium value $F_{w}^{*}=0$, the market has belief $p=0$, and the expected payoff of the bad firm is: $\gamma_{0} \frac{B}{2}+\gamma_{1} \frac{B}{2}$. If it deviates to $F=F_{G}$, the market will have belief $p=1$, and the expected payof lor the bad firm will be: $\gamma_{0}\left(\frac{G}{2}-\frac{F_{G} C}{G}\right)+\gamma_{1}\left(\frac{B}{2}-\frac{F_{G} C}{B}\right)$. Therefore, a bad finm will not deviate to $F=F_{G}^{\infty}$ if: $\gamma_{0}\left(\frac{G}{2}-\frac{F_{G} C}{G}\right)+\gamma_{1}\left(\frac{B}{2}-\frac{F_{G}^{*} C}{B}\right) \leq \gamma_{0} \frac{B}{2}+\gamma_{2} \frac{B}{2}$, or if:

$$
\gamma_{0}\left(\frac{G}{2}-\frac{F_{G} C}{G}-\frac{B}{2}\right) \leq \gamma_{1} \frac{F_{G}^{H} C}{B}
$$

If tho bad firm flevatues to $F \neq F_{G}$, the market can have any belief $p$, and the expected Payofl for the bad firm will be: $\gamma_{0}\left(p\left(\frac{C}{2}-\frac{E C}{G}\right)+(1-p)\left(\frac{B}{2}-\frac{F C}{B}\right)\right)+\gamma_{1}\left(\frac{B}{2}-\frac{F C}{B}\right)$. Therefore, the bad firm will not deviate to $f \neq F_{G}^{*}$ if: $\gamma 0\left(p\left(\frac{G}{2}-\frac{F G}{G}\right)+(1-p)\left(\frac{B}{2}-\frac{F C}{B}\right)\right)+\gamma_{1}\left(\frac{B}{2}-\frac{F G}{B}\right) \leq$ $70 \frac{13}{2}+7 \frac{18}{2}$, or: if:

$$
\gamma_{0}\left(p\left(\frac{G}{2}-\frac{F G}{G}\right)+(1-p)\left(\frac{B}{2}-\frac{F C}{B}\right)-\frac{B}{2}\right) \leq \gamma_{1} \frac{F C}{B}
$$

Botlu inequality (4.A.1) and (4.A.2) have to be satisfied. Note that (4.A.2) can always be satisted by imposing $p=0$. However, (4.A.1) will not be satisfied for very low values of $F_{C}$, bocanse the left-hand side (LHS) is decreasing in $F_{G}^{*}$, and the right-hand side (RHS) increasing. We on therefore calculate the lower bound $F_{G \text {, min }}$ on $F_{G}$ by equalizing the 
LHS and RHS of (4.A.1), and rearranging. Hence, $\gamma_{0}\left(\frac{Q}{2}-\frac{F_{Q}^{*} O}{G}-\frac{B}{2}\right)=\gamma \frac{F_{S}^{*} C}{B}$, or:

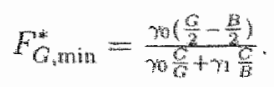

Now consider the good firm. The good firm will not deviate to $F=F_{B}^{*}=0$ if: $\gamma_{0} \frac{B}{2}+\gamma_{1} \frac{G}{2} \leq \gamma_{0}\left(\frac{G}{2}-\frac{F_{G}^{*} C}{G}\right)+\gamma_{1}\left(\frac{G}{2}-\frac{F_{G}^{*} C}{G}\right)$, or if:

$$
\gamma\left(\frac{G}{2}-\frac{F_{G}^{*} C}{G}-\frac{B}{2}\right) \geq \gamma_{1} \frac{F_{G}^{*} C}{G}
$$

The good firm will not deviate to $F \neq F_{B}^{*}=0$ if: $\gamma_{0}\left(p\left(\frac{C}{2}-\frac{F C}{G}\right)+(\mathbb{1}-p)\left(\frac{B}{2}-\frac{F C}{B}\right)\right)+$ $\gamma_{1}\left(\frac{G}{2}-\frac{F C}{G}\right) \leq \gamma_{0}\left(\frac{G}{2}-\frac{F_{G}^{*} C}{G}\right)+\gamma_{1}\left(\frac{G}{2}-\frac{F_{g}^{*} C}{G}\right)$, or if:

$$
\gamma_{0}\left(\frac{C}{2}-\frac{F_{G}^{*} C}{G}-\left(p\left(\frac{G}{2}-\frac{F C}{G}\right)+(1-p)\left(\frac{B}{2}-\frac{F C}{B}\right)\right) \geq \gamma_{1} \frac{\left(F_{G}^{*}-F\right) C}{G} .\right.
$$

Again, both inequality (4.A.4) and (4.A.5) have to be satisfied. From (4.A.4) we see that this will not hold for sufficiently high values of $F_{G}^{*}$, because the LHS is decreasing in $F_{G}^{*}$, and the RHS increasing. Therefore, we can calculate an upper bound $F_{G, \text { inax }}^{*}$ on $F_{G}^{*}$ by equalizing the LHS and RHS of (4.A.4), and rearranging. Hence, $\gamma_{0}\left(\frac{C}{2}-\frac{F_{C} C}{C}-\frac{B}{2}\right)=$ $\gamma_{1} \frac{f_{G} C}{G}$, or:

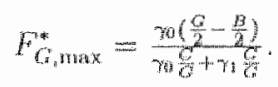

Moreover, if (4.A.4) is satisfied, (4.A.5) can also be satisfied by imposing $p=0$. Note that, for deviations off the equilibrium path, we use the same belief $p=0$ for both the bad and the good firms.

Finally, as mentioned in Footnote 11, any equilibrum debt level has to be smaller than or egual to $G$.

\section{Proof of Lemma 3}

In Lemma 1 we have allready seen that $a=p$ is always optimal for the receiver. This leaves us to prove that neither type of the sender can profitably deviate. The calculations are more or less similar to those of the proof of Lermma 2.

A manager of a bad firm will not deviate if: $\gamma_{0}\left(p\left(\frac{G}{2}-\frac{F C}{G}\right)+(1-p)\left(\frac{B}{2}-\frac{P_{C}}{B}\right)\right)+\gamma_{1}\left(\frac{B}{2}-\right.$ 


$$
\begin{aligned}
& \left.\frac{P C}{B}\right) \leq \gamma\left(\theta\left(\frac{G}{2}-\frac{F^{*} C}{B}\right)+(1-\theta)\left(\frac{B}{2}-\frac{F^{*} C}{B}\right)\right)+\gamma\left(\frac{B}{2}-\frac{F^{*} C}{B}\right) \text {, or if: } \\
& \gamma_{0}\left(\theta\left(\frac{G}{2}-\frac{F C}{G}\right)+(1-\theta)\left(\frac{B}{2}-\frac{F \cdot C}{B}\right)-p\left(\frac{G}{2}-\frac{F C}{G}\right)-(1-p)\left(\frac{B}{2}-\frac{F C}{B}\right)\right) \geq \gamma\left(\frac{\left(F+-F^{2}\right) C}{B} .\right.
\end{aligned}
$$

Notes that (4.A.7) will not be satisfed for sufficiently high values of $F^{*}$, because the UHS is decreasing in $F^{*}$, while the RHS is increasing in $F^{*}$. An upper bound on $F^{*}$ can be calculated by equalizing the LHS and RHS of (4.A.7) for $p=0$ and $F=0$, and fearranging. If $f^{*}$ is greater than this, the manager of the bad firm will always devate to $F=0$, even for belief $p=0$. Moreover, if $(4 . A .7)$ is satisfied for $F=0$, it will a fortzori be satisfied for $F>0$, agam by imposing $p=0$. Hence, $\gamma_{0}\left(\theta\left(\frac{G}{2}-\frac{F^{*} C}{G}\right)+(1-\theta)\left(\frac{B}{2}-\frac{F^{*} C}{B}\right)-\frac{B}{2}\right)=$ $7 \frac{E^{*} Q}{B}, \mathrm{or}$

$$
F_{\max }=\frac{\gamma_{0} \theta\left(\frac{C}{B}-\frac{p}{2}\right)}{\gamma_{0}\left(\theta \frac{C}{C}+(1-\theta) \frac{Q}{B}\right)+\gamma_{1} \frac{C}{B}}
$$

A manager of a good firm will not deviate if: $\gamma\left(p\left(\frac{G}{2}-\frac{F C}{G}\right)+(1-p)\left(\frac{B}{2}-\frac{P C}{B}\right)\right)+\gamma_{1}\left(\frac{G}{2}-\right.$ $\left.\frac{F C}{G}\right) \leq \gamma_{0}\left(\theta\left(\frac{C}{2}-\frac{F^{*} C}{G}\right)+(1-\theta)\left(\frac{B}{2}-\frac{F^{*} C}{B}\right)\right)+\gamma_{1}\left(\frac{C}{2}-\frac{F^{*} C}{G}\right)$, or if:

$$
\gamma_{0}\left(\theta\left(\frac{G}{2}-\frac{F^{*} C}{G}\right)+(1-\theta)\left(\frac{B}{2}-\frac{F^{*}}{B}\right)-p\left(\frac{G}{2}-\frac{F C}{G}\right)-(1-p)\left(\frac{B}{2}-\frac{F C}{B}\right)\right) \geq \gamma_{1} \frac{(F+F) C}{G}
$$

For all deviations $F<F^{n+},(4$. A.9) is always satisfied if (4.A.7) is satisfied. Moreover, for deviations $F>F^{*},(4 . A .9)$ can always be satisfied by imposing $p=0$.

Again note that, for deviations off the equilibrim path, we use the same belief $p=0$ for both the bad and the good firms.

Finkly, as mentioned in Footnote 11, any equilibrim debt level has to be smaller than ari conal to $\mathrm{C}$.

\section{Proof of Lemma 4}

We stat by proving that no pooling equilibrim can survive the intuitive criterion if $C$ is sufticienty ligh. Given a pooling equilibrim with $F^{*}$, we can always find an $F>F^{*}$ which is equilibrim-dominated for the manager of the bad firm and not for the manager of the good firm, as follows. In any pooling equilibrum, the equilibrimm payoff for the manager of the had firm is: $\gamma_{0}\left(\theta\left(\frac{B}{2}-\frac{F^{*} C}{G}\right)+(1-\theta)\left(\frac{B}{2}-\frac{F^{*} C}{B}\right)\right)+\gamma_{1}\left(\frac{B}{2}-\frac{F^{*} C}{B}\right)$. If he deviates to $F$, the best that can happen to him is that the receiver has a belief that he is a 
good type $(p=1)$, which would result in an expected payoff of: $\gamma_{0}\left(\frac{Q}{2}-\frac{k C}{C}\right)+\gamma_{1}\left(\frac{B}{2}-\frac{k C}{B}\right)$. A deviation $F$ for the manager of the bad firm is, therefore, equilibrium-dominated if: $\gamma_{0}\left(\frac{G}{2}-\frac{F C}{G}\right)+\gamma_{1}\left(\frac{B}{2}-\frac{F C}{B}\right)<\gamma_{0}\left(\theta\left(\frac{Q}{2}-\frac{F^{*} C}{G}\right)+(1-\theta)\left(\frac{B}{2}-\frac{F^{*} C}{B}\right)\right)+\gamma_{1}\left(\frac{B}{2}-\frac{F^{*} C}{B}\right)$, or if

$$
\gamma_{0}\left(\theta\left(\frac{G}{2}-\frac{F^{*} C}{G}\right)+(1-\theta)\left(\frac{B}{2}-\frac{F^{*} C}{B}\right)-\left(\frac{G}{2}-\frac{F C}{G}\right)\right)>\gamma_{1} \frac{\left(F^{*}-F C C\right.}{B} .
$$

If $\bar{F}$ is the value of $F$ for which the two sides of (4.A.10) are equal, the signal $\vec{F}+\varepsilon$ is equilibrium-dominated for the bad manager. Using the intuitive criterion, this implies that the market must have belief $p=1$ after signal $F+\varepsilon$. The reader will notice that (4.A.10), apart from the inequality sign, is the same as (4.A.7) with $p=1$. Comparing (4.A.7) and (4.A.9), we know that after signal $\tilde{F}+\varepsilon,(4$. A.9) will not be satisfied for $p=1$, because $B<G$. This implies that the pooling equilibria cannot survive the intuitive criterion, because the manager of the good firm can always gain from deviating to $\tilde{F}+\varepsilon$.

By rearranging (4.A.10) with equality, we obtain:

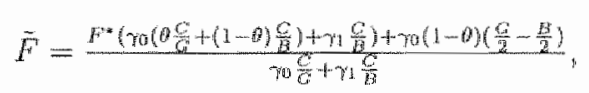

which typically depends on $F^{* *}$.

We should verify, however, whether an $F$ slightly larger than $\vec{F}$ is feasible, i.e, if $\ddot{F}<G$. We will check this for the highest possible value of $F^{*}, F_{\max }^{*}$, because from the positive relation between $\vec{F}$ and $F^{*}$ in (4.A.11) it is clear that if $\tilde{F}<G$ for $F_{\text {rawa }}^{*}$, with hold for all feasible $F^{*}$.

Define $\tilde{F}_{\max }$ as the $\tilde{F}$ which results from (4.A.11) with $F^{*}=F_{\text {max }}^{*}$ Sulstituting (A.A.B) into (4.A.11), and rearranging, we have:

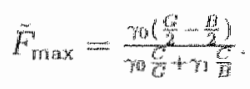

From (4.A.12) we can calculate a $C^{*}$ such that if $C>C^{*}, \tilde{F}_{\text {max }}<C$. This gives:

$$
C^{\prime \prime}=\frac{\gamma_{0}\left(\frac{6}{2}-\frac{\alpha}{2}\right)}{\gamma_{0}+\gamma_{1} \frac{C}{\beta 3}}
$$

which is equal to equation (4.7) in the text. 
Hence, if $C>C$, there are no poling equibriat that can survive the intuitive criterion. It is straightorward to check that if $C \leq C^{*}$, there will be a continum of pooling equilibria that will survive the intuitive criterion, from some value for $F^{*}$ up to $F_{\text {max }}^{*}$

It remains to prove that if $C \geq C^{*}$, the unique value for $F_{G}^{*}$ in a separating equilibrium is F, mote that $F_{G}$, Nan is the minimum value for $F_{G}^{*}$ to prevent the manager of the bad firm from irmitating the good one, which was already shown in the derivation of (4.A.1). This means that all $F>F_{G, m i n}^{*}$ are equilibrium-dominated for the manager of the bad firm. But that directly implies that any separating equilibrium with $F_{G}>F_{G \text {, min }}$ will newer survive, because the manager of the good firm could always deviate to $F_{G}^{*}$ min (or more precisely $F_{G \text {, nif }}^{*}+\varepsilon$ ), holding constant his period 1 value as perceived by the market and lowering his expected bankruptcy costs in period 2.

Athough we now know that $F_{G}^{*}$ in in the only value for $F_{G}^{*}$ that can survive the intuitive criterion, we still have to check when this value is feasible, i.e., smaller than or equal to $G$. Since $F_{G, \text { min }}$ is equal to $\tilde{F}_{\text {max }}$, we know that a separating equilibrium can only survive if $C$ is greater than on equal to $C^{*}$. Otherwise, no separating equilibrium can survive. 


\section{Chapter 5}

\section{The Option to Fire A Manager}

\subsection{Introduction}

Most developed countries nowadays have a corporate system in which the employees enjoy some form of employment protection, i.e., they cannot be fired without a good reason. "This employment protection is a comforting instrment from the point of view of the enployees, but it also is an efficient mechanism from the point of view of the firm. If there was no employment protection, employees would probably denand a higher salary, in order to compensate them for the potential firing costs they incur when they are fired. These firing costs can be thought of as a non-recurrent expense to find a new job or to move fo mother place.

However, if the increase in the value of the firm due to fring an incumbent muloyes and hiring a new one offsets the compensation for the firing costs, the firm night prefer at system with less or no employment protection. This is what we observe in practice for managers at the top of the hierarchy, because their capability largely influences firm value. In this chapter we will therefore focus on the fact that firms may need different typos of managers at different times. Even if the incumbent. marager doos the best lue can, the shareholder may still want to have the possibility to fire him, because at some moment in time another manager, with other characteristics, might simply be better suited for the firm. The shareholder takes account of this by means of a contract which allows him to 
fire the incumbent manager at any moment in time."

We consider a simple setting in which a shareholden has to hire a manager in order for his fim to generate a profit. For simplicity we assume that the value of the firm entirely depends on the "profit capacity' of the incumbent manager. The option to fire the incumbent manager is vallable for the shareholder, because it allows him to hire an altemative manager who has a higher proft capacity than the moumbent. The cost of this option is caused by the fact that the manager will incur personal firing costs if he is fired, and needs to be dompensated for them. It is important to note that the compensation for these fring costs is an irreversible cost for the shareholder. In other words, once the shareholder has fred the incumbent manager, he can never reverse this decision and recover the compensation for the firing costs. We assume that the fing costs are stochastic. The stochastic character of the firing costs is a natural assumption since, at the moment when the contwact is written, the manager"s job market position when the is fired is uncertain.

Casmal observation from practice shows that the compensation for the expected firing costs can take two extreme forms. In the first system, which we define as ex-ante compensation, the manager receives a compensation in each period that he is still employed, e.g., by means of a higher salary. In the second system, which we define as ex-post compensation, the manager receives a severance payment at the moment he is fired.

In this chapter we show that, with the system of ex-ante compensation, the shareholder Thas a commitment problem, als follows. If the compensation takes place by means of a higher sitary, the sharelolder has the incentive to fire the incumbent manager relatively often, rasulting in high oxpected fring costs. Since the manager will anticipate this, he will require a largo compensation. The shareholder would like to promise the manager to fro linu in fewer cases, i.e, to fre him only for a higher walue of the profit capacity of tho atternative manager. In that case, the positive effect of the lower expected firing costs would more than outweigh the negative effect of the limited possibilities to fire the manger:

\footnotetext{
"Most of the literume on the relntionship beween shateholders and managers (or, more generally, the pritciph-agan literature) ws concerned with the motikational aspects of the contract. See, for example. Ross (1973). Hohnstom (1979). Grossman and Hart (1983), and Holmstrom and Milgroma (1987). For anpirical evidence on incentive contucts, see, for axample, Jensen and Murply (1990) and Garen (1904).
} 
However, the shareholder has no credible means to commit himself, because once the (lower) compensation has been setted in a contract, he would still have the incentive to fire the manager for a lower value of the profit capacity of the atematwe manager than promised. Specifying the vahe of the profit capacity of the aternative manager for which the incumbent manager can be fred will not solve the problem, because this profit capacity is an unverifiable variable. That is, any confict about the actual value of the profit capacity of the altemative manager cannot be solved in a court of law. For example, the court may lack the information or the skills to properly estimate this value.

An important result of this chapter is that the system of ex-post compensation party solves this commitment problem. The intuition is as follows. If the compensation talkes place by means of a severance payment at the moment that the manager is fred, the cost of firing the manager becomes larger. This will have the effect that the shareholder fires the manager in fewer cases, i.e, altennative managers have to be better before the incumbent: manager is fired. Hence, the severance payment serves as a credible commitment device for the shareholder to fire the manager in fewer cases, thereby diminishing the commitment problem. This provides a rationale for the severance payment, which is often surrounded. by a large amount of negative publicity.

Although the system of ex-post compensation outperforms the system of ex-ante compensation, it tums out that it still does not result in the first best solution. In the first best solution, the shareholder has no commiment problem, i, e, the profit capacity of the altemative manager is a verifiable variable which can be specifed in a contact. Howewor, we will show that by using a combination of both ex-post and ax-ante compensation, the shareholder can always design a contract that imitates the first best solution."

Both the type of business in which the firm operates and the labor market conditions will determine whether there exists a positive or negative correletion botween the profit capacity of altemative managers on the market and the firing costs of the incumbent: manager. Positive comelation is likely if, for example, a large difference in tho profit,

\footnotetext{
${ }^{2}$ A passible extersion of on model could be to thate notice of the fact that when the shareboloter fires

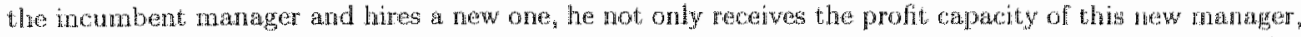

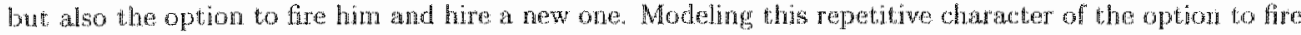
a manager would increast the option value, but would not qualitatively change our rant to
} 
capacity of the attcrative and the incumbent manager is caused by the fact that the skils of the latter have become uneuited for most jobs. In that case he may incur high search costs, or he may need some costly retraining. A negative comrelation is expected if, for sxample, a large difference in the profit capacity of the alternative and the incumbent manager occurs at moments of a highly dynamic labor market in which many firms are looking for a change in management style. In that case, the fred manager will encounter reatively few problems in finding a new job.

An important result with respect to this correlation is that the expected fring costs are positively reated to the correlation. The intuition for this is as follows. Fining takes place as soon as the profil capacity of the altermative manager reaches some (relatively high) value. If there is a positive correlation between the profit capacity of the alternative manager and the firing costs of the incumbent manager, then this firing will take place, on average, for high realizations of these fring costs. A concomitant result is that the option value for the shareholder will decrease for increasing correlation, a result which holds for the frst best solution as well as for the systems of ex-ante and ex-post compensation.

A related branch of literature starts with the seminal work of Oi (1962), who shows that labor is a quasi-fixed factor of production. Follow up papers almost invariably take up the question of how hiring and firing costs affect the frms' optimal employment policies, and look att the consequences for long-rum employment le.g., Bentolila and Bertola (1990), Bertola (1900), and Peeters (1997)]. However, in contrast to our model, the firing (and diring) costs are now-stochatic in these papers, and alternative mechanisms to compensate for the expeted fring costs are not: considered. Tho other papers that have explicitly wodied the option to fire a manager are Acharya (1992), and Cremer (1995). In both papers, the threat of fring forms an integral part of the package of incentives. Onr model abstracts from incentive considerations. The resulting relatively simple structure allows as lo forus on the relation between the nature of the firing costs of the manager and the optimal way in which the shareholder should compensate the manager for his expected firing costs.

The remandes of this chapter is as follows. Section 5.2 presents the basic model. In Sotion 5.3 we derive some general results that will hold throughout the chapter. The first 
best solution is derived in Section 5.4. In Sectons 5.5 and 5.6 we develop the systems of exante and ex post compensation, respectively. Section 5.7 then compares the two systems, and Section 5.8 shows that the first best solution can be obtained by a combination of he two. Finally, Section 5.9 conclucles.

\subsection{The Basic Model}

A shareholder needs a manager to run his firm. For simplicity, we assume that the value of the firm only depends on the capabilities of the incumbent manager." We model this idea by letting the value of the firm be equal to the profit capacity (capability) of the incumbent manager. Without loss of generality, we assume that both the shareholder and the managen are risk neutral.

There is a labor market where the profit capacity of an altermatiwe manager for the firm, $V$, evolves stochastically over time. We assume that $V$ follows a geometric Brownian motion, with drift parameter $\mu_{v}$ and variance parameter $\sigma_{v}^{2}$ :

$$
d V=\mu_{2,} V d t+\sigma_{t,} V d z_{i j}
$$

where $d z_{v}$ is the increment of a Wiener process. The profit capacity of the incumbent manager could of course be subject to changes as well, but since we are only interested in the difference between the profit capacity of altemative managers and the incumbent. manager, we assume for simplicity that the proft capacity of the latter remains constant at $V_{0}$.

When the shareholder hires a manager for his firm (with profit capacity $V_{0}$ ), they have to agree upon a contract. The contract between the shargholder and the manager stipulates that the latter can be fired at any moment in time. Hence, the shareholder (or the fimm) has the option to fre the manager. The value of this option is donoted by $F(V)$. We assume that if a manager is fired, he will be able to obtain his reservation wage, which is set equal to zero for simplicity, somewhere dse. Moreover, the new manager will also

\footnotetext{
"The option walue $F(V)$ as dischssed below in this section is rot included in this value of the firm.
} 
recenve his reservation wage of xero. However, if a manager is fired, he incurs personal fring costs $C$. Simce it is the manager who bears these personal firing costs, he needs to be compensated for them.

This compensation can take two extreme forms. The first possibility is that the manager reccives a compensation in each period that he is still employed (ex-ante compensation). The second possibility is that the manager receives a severance payment $P$ at the moment he is fired (ex-post compensation). In both cases the manager will only agree to participate if the expected value of the promised payments equals or exceeds the expected firing costs.

The firing costs $C$ also follow a geometric Brownian motion, with drift parameter $\mu_{c}$ and variance parameter $\sigma_{c}^{2}$ :

$$
d C=\mu_{c} C d t+\sigma_{c} C d x_{C}
$$

The processes of both $V$ and $C$ are common knowledge. However, the reallizations of both variables are non-verifiable. This implies that no feasible contract can be written which is based on either of the two variables. The correlation between $d z_{3}$ and $d z_{c}$ is denoted by $\rho$.

The cost of exercising the option, 1 .e., the exercise price, is denoted by $I$. It is important to distinguish this cost of exercising the option from the compensation that the manager receives from the shareholder for his expected firing costs. As stated above, the manager somehow has to be compensated for his expected firing costs, but this compensation does not necessaty come the moment of firing. In fact, it turns out that the optmal exercise patten of the option ard, hence, its value, crucially depends on the way the manager is compensated for his fring costs.

\subsection{Preliminary Results}

This scction provides a short introduction to real option theory, and derives some general formulas that will be used later in the chapter.

\footnotetext{
${ }^{4}$ One why to juthly the frot that new managers (with $V>V_{0}$ ) also receive the zero reservation wage is thet the form has al the barganing power after the "match' between the firm and the new manager soe, c.e., Diamond (1082).
} 


\subsubsection{Option Value, Critical Value, and Expected Time of Firing}

The firing option can be seen as a non-dividend paying asset. Therefore, as long as it is not exercised, its total expected return over a short interwal of time equals its expected capital appreciation. This gives us the following Bellman equation:

$$
\lambda F(V) d t=E[d F(V)]
$$

where $\lambda$ is the discount rate. Using a second-orcer Taylor expansion, we can express $d F(V)$ as:

$$
d F(V)=F^{\prime}(V) d V+\frac{1}{2} F^{\gamma /}(V)(d V)^{2}
$$

Combining $(5.1),(5.3)$ and $(5.4)$, and rearranging, gives us the following second-order homogeneous Cauchy-Euler differential equation:

$$
\frac{1}{2} \sigma_{w}^{2} V^{2} F^{\prime \prime}(V)+\mu_{v} V F^{2}(V)-\lambda F(V)=0
$$

In addition, we have the usual value-matching and smooth-pasting conditions:

$$
\begin{aligned}
& F\left(V^{*}\right)=V^{*}-I \\
& F^{*}\left(V^{*}\right)=1
\end{aligned}
$$

where $V^{*}$ is the criticall value, which is defined as the optimal value $V$ to exercise the option to fire the incumbent menager with profit capacity $V_{0}$, and hire a now manager with profit capacity $V^{*}$

Using the conditions in (5.6) and (5.7), the solution to equation (5.5) can be expressed as [e.g. McDonald and Sigel (1986)]:

$$
F(V)=\left(\frac{V}{V^{*}}\right)^{B}\left(V^{*}-I\right)
$$

where $B=\frac{1}{2}-\frac{t_{v}}{\sigma_{v}^{2}}+\sqrt{\left(\frac{a_{v}}{\sigma_{w}^{2}}-\frac{1}{2}\right)^{2}+\frac{2 \lambda}{\sigma_{w}^{2}}}>1$. In expression $(5.8),\left(V^{*}-I\right)$ is the payoff at: the moment of exercising, and $\left(\frac{V}{V^{*}}\right)^{B}$ can be interpreted as a discount factor.

Using the two boundary conditions in $(5.6)$ and $(5.7)$, we can also solve for the critical 
value $V^{*}$ :

$$
V^{*}=\frac{B}{B-\pi} I
$$

We have $B>1$, which implies that the simple NPV rule for firing does not hold in this context. The intuition for this is as followrs. Exercising the option to fire the incumbent manager as soon as $V>1$ implies an immediate gain to the shareholder. However, the shareholder can do better by keping his option alive. This enables him to take advantage of a possible increase in the profit capacity of the potential manager. To be sure, this profit capacity can also decrease, but this is of less importance to the shareholder, since he will not exercise his option in those cases.

Finally, we can establish the expected time $T$ at which the manager is fired. Note that by applying Ito's lemma, (5.1) can be rewritten as:

$$
d \ln V=\tilde{\mu}_{v} d t+\sigma_{v} d z_{v}
$$

where $\tilde{\mu}_{v}=\mu_{n}-\frac{1}{2} \sigma_{w}^{2}$. Taking expectations in (5.10) and rearranging, we have:

$$
E[T]=\frac{\ln V^{*}-\ln v_{0}}{\mu_{w}}
$$

\subsubsection{Expected Firing Costs}

The expected firing costs for the manager can be defined as:

$$
E \mid C]=E\left[e^{-\lambda T} C_{T}\right]
$$

where $T$ is the first moment at which $V=V^{*}$, and $C_{T}$ is the realization of the stochastic firing costs at the moment of firing. Hence, $T$ is the first passage of time of a Brownian motion hitting a constant barrier. In the Appendix, we proof the following lemma:

\footnotetext{
5This is a stancard result which can be found in any textbook on real option theory. For an intuitive introduction to real option theory, see eng. Dixit and Pindyck (1994).
} 
Lemma 1 The expected firing costs for the mannger can be expressed as:

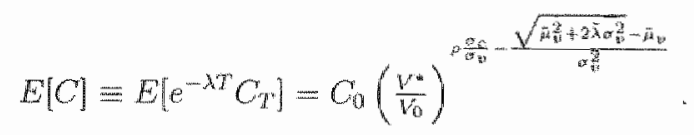

where $\bar{\lambda}=\lambda+\rho \frac{\sigma_{c}}{\sigma_{v}} \tilde{\mu}_{v}+\frac{1}{2} \sigma_{c}^{2} \rho^{2}$.

Lemma 2 The expected firing costs are decreasing in the critical value $V^{*}$.

Proof We need to show that the partial derivative of the expected firing costs with respect to the critical value is negative. This partial derivative can be calculated as:

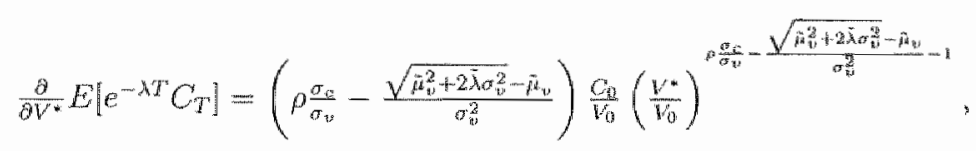

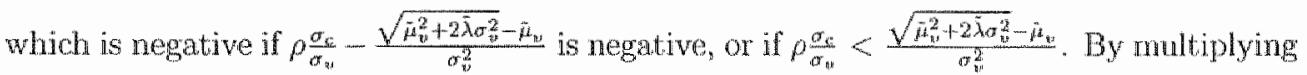
both sides by $\sigma_{w}^{2}$, adding $\tilde{\mu}_{v}$, and squaring, we get the following inequality: $\rho^{2} \sigma_{c}^{2} \sigma_{v}^{2}+\tilde{\mu}_{v}^{2}+$ $2 \rho \sigma_{c} \sigma_{v} \tilde{\mu}_{v}<\tilde{\mu}_{v}^{2}+2 \tilde{\lambda} \sigma_{v}^{2}$. Substituting $\tilde{\lambda}=\lambda+\rho \frac{\alpha_{c}}{\sigma_{v}} \tilde{\mu}_{v}+\frac{1}{2} \sigma_{c}^{2} \rho^{2}$ and eliminating, we get the condition $2 \lambda \sigma_{v}^{2}>0$, which is obviously satisfied.

The intuition for Lemma 2 is as follows. Note that the expected firing costs are the expected realization of the firing costs at the moment of firing, discounted back to the period when the contract between the shareholder and the manager is signed. If the critical value increases, the expected moment of firing increases, which implics that the (discounted) expected firing costs decrease

\subsection{The First Best}

The contract between the shareholder and the manager cannot make use of a criticall walue which specifies when the manager is fired. The reason for this is that $V$ is unverifiable, which implies that the manager cannot rely on the contract. In other words, whenever the shareholder has a profitable opportunity to deviate from the specified critical value in the contract, he will do so. In fact, given any contract, the manager can deduce sat which critical value he will be fired. We will define this as the equilibrium oritical value. It is this 
equilibrim critical whe that the mavager will we in his calculations for his compensation for his expected fring costs.

A commitment problem for the shareholder arises whenewer the equilibrium critical value is lower than the optimal critical value. In those cases the shareholder would like to commit himself to fire the rnanager at a higher critical value than the equilibrium critical value, in order to reduce the expected fring costs (see Lemma 2). However, this contract. is not feasible, because of the verifiability problem.

A first best solution is obtained it a contract between the shareholder and the manager does not suffer: from this commitment problem. In other words, the shareholder can choose a critical value that optimizes his option value in (5.8) net of the compensation for the expected firing costs in (5.13). The optimization program for the shareholder is then as follows:

$$
\max _{V \rightarrow \infty} F(V)_{f b}-E[C]_{f b}
$$

where $f b$ stands for first best.

Numerical results for the program in (5.14) are presented in Section 5.7. Figure 5-1 shows a graphical solution to the first best problem for the parameter values mentioned below the figure.

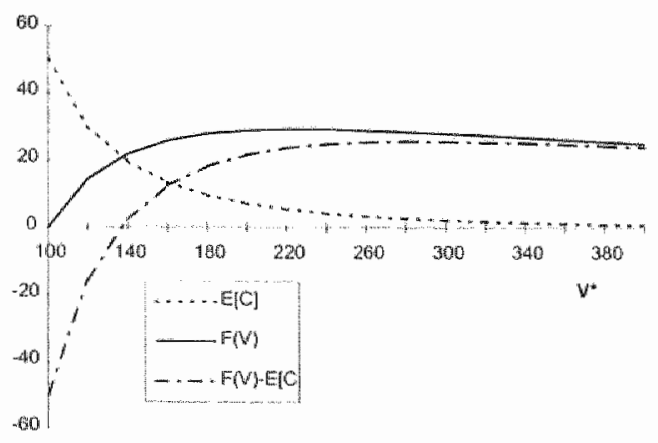

Figure 5-1: Graphical representation of the first best solution, for the following parameter values: $C_{0}=50, V_{0}=100, \mu_{s}=0.04, \sigma_{c}=0.2, \sigma_{v}=0.2, \lambda=0.1, \rho=-1$.

\footnotetext{
"All the mumerical results that are presented in this chapter are robust to changes in the parameter values
} 
First consider the option walue. The cast of exercising the option is the profit capacity of the incumbent manager, in this example 100 . Therefore, the option value will only be positive for critical values greater than 100. Increasing the critical value then first increases the option value. The maximum is attained at a critical value of 226 . The fact that $226>100$ illustrates the standard result of real option theory as explanned in Section 5.3. Secondly, as mentioned in Lerma 2, the expected firing costs decrease with an increasing critical value. Finally, the net option value is simply the difference between the option value and the expected firing costs, and its maximum in this example is attained at a critical value of 287.

\subsection{Ex-Ante Compensation}

Under the system of ex-ante compensation, the shareholder does not have to pay an additional amount to the manager at the moment of firing. Hence, the only relevant cast of firing is the profit capacity of the incumbent. manager:

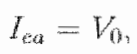

where ea stands for ex ante.

Using (5.8), (5.9), and (5.11), we can establish the option value, the critical value, and the moment of firing under ex-ante compensation, respectively, as:

$$
\begin{gathered}
F(V)_{c a}=\left(\frac{V}{W_{c a t}^{*}}\right)^{B}\left(V_{e a}^{*}-I_{c a b}\right), \\
V_{e a}^{*}=\frac{B}{B-1} I_{e s s}
\end{gathered}
$$

and

$$
E[T]_{c a}=\frac{\ln V_{e i s}^{*}-\ln V_{0}}{\ddot{\mu}_{x n}}
$$




\subsubsection{Expected Firing Costs}

The calculations for the expocted fining costs were undertaken in Section 5.3.2. Using Lemma (1), we have:

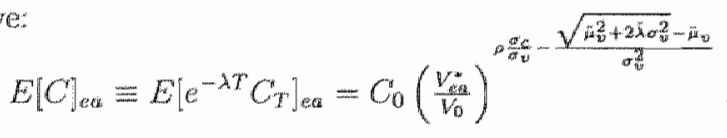

In Lemma 3 we claim that the expected firing costs and the option value do not change If the manager receives a lump sum payment $L$ at the start of the contract instead of a compensation in each period that the is still employed. Therefore, we can truly speak of ax-ante compensation.

Lemma 3 The expected firing costs under the system of a compensation in each period that the manager is still employed are exactly the same as wnder the system of a lump sum payment at the start of the contract.

Proof Suppose each period lasts for $\tau$ years. The expected hring costs are:

$$
E\left[e^{-\lambda T} C ; 0<T<\tau\right]+E\left[e^{-\lambda T} C ; \tau<T<2 \tau\right]+\ldots
$$

where $E[Z ; A]=\int_{A} Z d A$. This reduces to:

$$
E\left[e^{-\cdots T} C ; 0<T<\infty\right]
$$

which is equal to (5.12).

Because there is no extra payment to the manager at the moment of firing, $I$ is still calculated according to $(5.15)$. This implies that the option value and the rritical value as calculated according to $(5.16)$ and $(5.17)$, respectively, do not change.

Lemma 4 The expected fing costs under exwhe compensation are whereasing in the coryedation $p$.

Proof Wo need to show that the partial derivative of (5.19) with respect to $\rho$ is positive. This partial derivative can be calculated as:

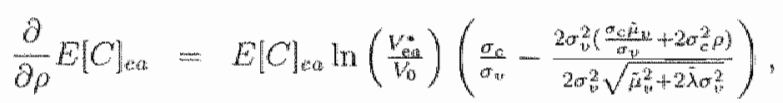




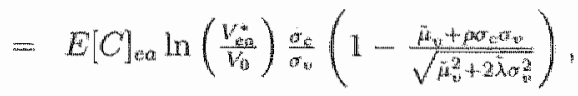

which is positive as long as $\left(\tilde{\mu}_{v}+\rho \sigma_{c} \sigma_{v}\right)^{2}<\tilde{\mu}_{v}^{2}+2 \bar{\lambda} \sigma_{v}^{2}$, or $2 \tilde{\mu}_{v} \rho \sigma_{c} \sigma_{v}+\rho^{2} \sigma_{c}^{2} \sigma_{v}^{2}<2 \dot{\lambda} \sigma_{v}^{2}$. By substituting $\tilde{\lambda}=\lambda+\rho \frac{\sigma_{c}}{\sigma_{v}} \tilde{\mu}_{v}+\frac{1}{2} \sigma_{c}^{2} \rho^{2}$, we get the condition $2 \lambda \sigma_{v}^{2}>0$, which is obviously satisfied.

The intuition for Lemma 4 is straightforward. Firing takes place as soon as the profit capacity of the potential manager, $V$, hits the barrier $V^{*}$. This happens without taking notice of the realization of the firing costs. Positive correlation between the firing costs and the profit capacity of the potential manager implies that firing takes place, on average, at high realizations of the firing costs.

Finally, combining Lemna 3 and equation (5.19), we have the following participation constraint for the manager under ex-ante compensation:

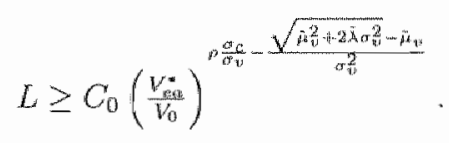

\subsubsection{The Optimal Ex-Ante Contract}

The shareholder wants to optimize his option value net of the compensation for the expected firing costs he has to pay to the manager for accepting the contract. Under the system of ex-ante compensation, this is a rather straightforward optimization problem. Using (5.20), we have the following optimization program for the shareholder:

$$
\begin{aligned}
& \max _{L} F(V)_{e a}-L \\
& \text { s.t. }
\end{aligned}
$$

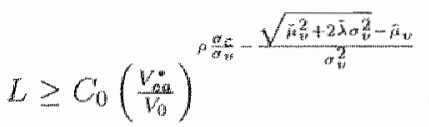

Taking a closer look at (5.15), (5.16) and (5.17), we see that the optimal critical value and option value do not depend on the amount of the compensation for the expected firing costs. This simply implies that the optimum for (5.21) is always attained by setting the 
lump sum payment equal to the expected firing costs:

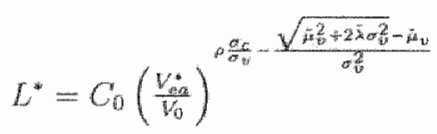

Wumerical results for the program in (5.21) are presented in Section 5.7 .

\subsection{Ex-Post Compensation}

Under ex-post compensation, the manager receives a severance payment $P$ at the moment he is fired. This implies that the cost of firing for the shareholder is now the profit capacity of the incumbent manager, plus the severance payment that the incumbent manager recerves if he is fired:

$$
I_{e p}=V_{0}+P
$$

where ep stinds for ex post.

The option value, critical value, and expected time of firing are again established according to (5.8), (5.9), and (5.11), respectively:

$$
\begin{gathered}
F(V)_{e p}=\left(\frac{V_{0}}{V_{e p}^{*}}\right)^{B}\left(V_{e p}^{*}-I_{e p}\right), \\
V_{e p}^{*}=\frac{B}{B-1} I_{e p,},
\end{gathered}
$$

and

$$
E[T]_{e p}=\frac{\ln V_{e p}^{*}-\ln V_{0}}{\tilde{H}_{t}}
$$

\subsubsection{Expected Firing Costs}

Under the system of ex-ante compensation, the manager received a lump sum payment at the siart of the contract as a compensation for the expected firing costs. This participation constraint was given in (5.20). Under the system of ex-post compensation, the compensalion for the expected firmg costs comes in the form of a severance payment at the moment What the manger is fired. The fact that the firing costs are non-verifiable implies that the 


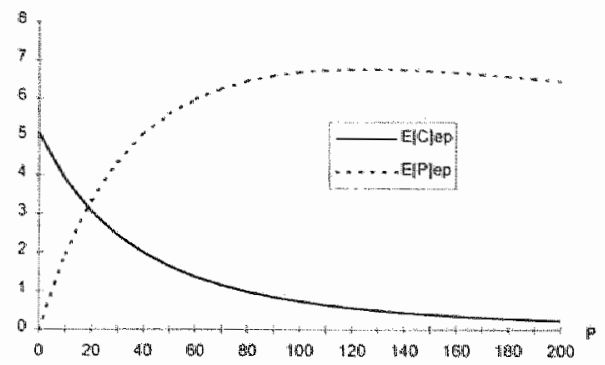

Figure 5-2: Graphical representation of the expected firing costs and the expected severmine payment as a function of the severance payment, for the following parameter values: $C_{0}=$ $50, W_{0}=100, \mu_{v}=0.04, \sigma_{c}=0.2, \sigma_{v}=0.2, \lambda=0.1, \rho=-1$.

severance payment cannot be made dependent on them, i.e., it has to be established at the start of the contract. The participation constraint for the managen therefore becomes:

$$
E\left[e^{-\lambda T}\right] P \geq E\left[e^{-\lambda T} C_{T}\right]
$$

Using Lemma. (1), we have:

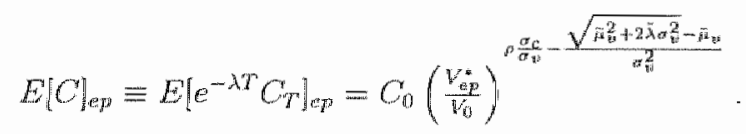

Using (5.A.4) (with $\tilde{\lambda}=\lambda$ ), we have:

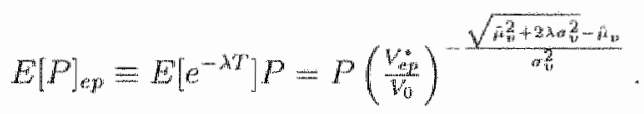

Both (5.28) and (5.29) depend on the severance payment $P$. Figure $5-2$ shows the general pattern of these two equations. Firsty, we observe that the expected firing costs are a decreasing function of the sewerance payment. The reason for this is straightorward. Increasing the severance payment increases the cost of firing (5.23), and therefore the critical walue (5.25). The effect of an increasing critical value has already been stated in Lempiac 2 . 
For the expected severance payment we observe the following. "Increasing the severance payment has the following two effects. The first (direct) effect is that the manager recewes a larger payment when he is fred, which increases the expected severance payment. However: the second (indirect) effect is that it increases the critical value, and hence, increases the expected moment in time at which the manager is fired. This second effect reduces the expected severance payment. We have therefore two opposing effects, and we see from Figure $5 \mathrm{~m} 2$ that for small values of the sewerance payment the former effect dominates, but for thigh vilues it is the latter effect that dominates.

Lemma 5 The expost option value is decreasing in the severance payment.

Proof We ned to show that the partial derivative of the option value in $(5.24)$ with respect to the severance payment, is negative. This partial derivative can be calculated as:

$$
\begin{aligned}
\frac{\partial}{\partial P} R(V)_{c p} & =\left(\frac{V_{0}}{V_{e p}^{*}}\right)^{B}\left(\frac{B}{B-1}-1\right)-\left(V_{e p}^{*}-I_{e p}\right)\left(B\left(\frac{V_{0}}{V_{p p}^{*}}\right)^{B-1} \frac{V_{0}}{\left(V^{*}\right)^{2}} \frac{B}{B-1}\right), \\
& =\left(\frac{V_{B}}{V_{e p p}^{*}}\right)^{B}\left(\frac{1}{B-1}-\frac{\left(V^{*}-l_{e p}\right)}{V^{*}} \frac{B^{2}}{B-1}\right)
\end{aligned}
$$

which is negative as long as $V^{*}<\left(V^{*}-I_{e p}\right) B^{2}$. By substituting $V^{*}=\frac{B}{B-1} I_{e p}$, we get the condition $\frac{B}{B-1} I_{e p}<\left(\frac{B}{B-1}-1\right) I_{e p} B^{2}$, or $\frac{B}{B-1}<\frac{B^{2}}{B-1}$, which is obviously satisfed since we have $B>1$.

Iumma 5 states that the option walue under the system of ex-post compensation is decrensing in the sewance payment. This is a standard result from option theory: the option value falls with the exercise price.

Note from Figure $5-2$ that the participation constraint for the manager is satisfied for firing premia at or to the right of the point of intersection of the two curves. Using Lemma 5 , the optimal severance payment is atwalished at the point of intersection. Using (5.28) and (5.29), the optimat severance paynent is given by:

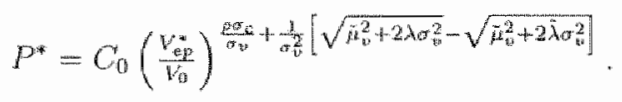

\footnotetext{
Thote that the word expected in expected severance payment only refers to the expectation of the noment in time at which the manager is fired, because the severance payment itself is a fixed amount, settled in the contract.
} 
Finally, we can estatish the effect of an increasing correlation on the optimal severance payment. Using Lemma 4, we know that, for every walue of $P$, the expected firing costs will increase with comrelation. This implies that the curve of the expected fring costs in Figure 5-2 shifts upwards with increasing correlation. From (5.29) it follows that the curve for the expected severance payment in Figure 5-2 does not depend on the correlation. Hence, an increasing correlation will shift the point of intersection in Figure 5-2 to the right, which implies that the optimal severance payment is positively related to the correlation. This is formally stated in Lemma 6.

Lemma 6 The optimal severance payment is increasing in the correlation $p$.

Proof We need to show that the partial derivative of the optimal severance payment in (5.30) with respect to $\rho$ is positive. This partial derivative can be calculated as:

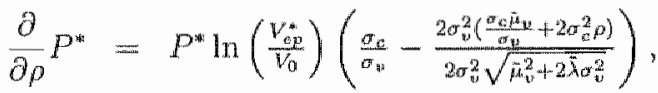

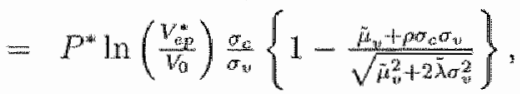

which is positive as long as $\left(\tilde{\mu}_{v}+\rho \sigma_{c} \sigma_{v}\right)^{2}<\tilde{\mu}_{v}^{2}+2 \tilde{\lambda} \sigma_{v}^{2}$, or $2 \tilde{\mu}_{v} \rho \sigma_{c} \sigma_{v}+\rho^{2} \sigma_{c}^{2} \sigma_{w}^{2}<2 \tilde{\lambda} \sigma_{v}^{2}$ By substituting $\tilde{\lambda}=\lambda+\rho \frac{\sigma_{\alpha}}{\sigma_{\mathrm{r}}} \tilde{\mu}_{v}+\frac{1}{2} \sigma_{c}^{2} \rho^{2}$, we get the condition $2 \lambda \sigma_{v}^{2}>0$, which is obviously satisfied.

\subsubsection{The Optimal Ex-Post Contract}

Similar to the system of ex-ante compensation, the shareholder wants to optimize his option value net of the compensation for the expected firing costs. However, this compensation now comes in the form of a severance payment at the moment of firing, and is already discounted in the option walue in (5.24). Therefore, we have the following optimization program:

$$
\begin{aligned}
& \max _{P} F(V)_{e p} \\
& \text { s.t. } \\
& E\left[e^{-\lambda T}\right] P \geq E\left[e^{-\lambda T} C_{T}\right]_{e p .} .
\end{aligned}
$$


Numerical results for the program in (5.31) are presented in Section 5.7. The analytical expression for the optimal severance payment has already been established in (5.30).

\subsection{Comparing Ex-Ante and Ex-Post Compensation}

Table 5.1 contains numerical results for the first best solution, ex-ante compensation, and ex-post compensation, respectively, for five different values of $\rho$. The first best results show that the optimal critical value increases for an increasing correlation. This is an intuitive result, which follows from Lemmas 2 and 4 . An increasing correlation increases the expected firing costs for every critical value, resulting in a higher optimal critical value. Finally, the met option value decreases for increasing correlation.

\begin{tabular}{|c|c|c|c|c|c|c|c|c|c|c|c|c|}
\hline & \multicolumn{5}{|c|}{ first best } & \multicolumn{4}{c|}{ ex ante } & \multicolumn{4}{c|}{ ex post } \\
\hline$\rho$ & $V^{*}$ & $E[C]$ & $F[V]$ & net & $V^{*}$ & $E[C]$ & $F[V]$ & $n e t$ & $P$ & $V^{*}$ & $E[C]$ & $F[V]$ \\
\hline-1.0 & 288 & 2.6 & 28.3 & 25.7 & 226 & 5.1 & 29.3 & 24.1 & 18.6 & 269 & 3.2 & 25.6 \\
-0.5 & 312 & 3.9 & 27.6 & 23.7 & 226 & 8.1 & 29.3 & 21.2 & 30.9 & 296 & 4.4 & 23.6 \\
0.0 & 340 & 5.6 & 26.8 & 21.2 & 226 & 11.6 & 29.3 & 17.7 & 50.0 & 340 & 5.6 & 21.2 \\
0.5 & 370 & 7.5 & 25.9 & 18.4 & 226 & 15.3 & 29.3 & 14.0 & 81.0 & 410 & 6.5 & 18.3 \\
1.0 & 399 & 9.6 & 25.1 & 15.5 & 226 & 18.9 & 29.3 & 10.4 & 136.5 & 535 & 6.8 & 14.8 \\
\hline
\end{tabular}

Table 5.1: Numerical results for the first best solution, ex ante compensation, and ex post compensation, for the following parameter values: $C_{0}=50, V_{0}=100, \mu_{w}=0.04, \sigma_{c}=0.2$, $\sigma_{w}=0.2, \lambda=0.1$.

The cx-ante results show that the critical value is unchanged by the correlation. Moreover, the critical value is always lower than the first best critical value. The shareholdwer would like to commit himself to use the first best critical value. In that manner the decrease in the expected firing costs would more than offset the decrease in the option value. We observe from the table that this commitment problem becomes more severe the larger the correlation.

The ex-post results show that the optimal critical value increases for an increasing correlation. This occurs because the compensation for the expected firing costs takes place by means of a severance payment. From Lemma 6 we know that the optimal severance payment increases with the correlation. From (5.23) and (5.25) it then follows that the critical value also increases for an increasing correlation. 
Comparing the systems of ex-ante and ex-post compensation, we observe that che optmal critical value under the latter system is always higher. From (5.18) and (5.26) we know this implies that the expected moment of firing is later in time for ex-post compensation than for ex-ante compensation.

From Table 5.1 it also becones clear that the ex-post compensation system is always better than the ex-ante compensation system. We can say that the ex-post compensation system party solves the commitment problem. However, although the (net) option value is always higher than with ex-ante compensation, we see that, except for zero comelation, the system of ex-post compensation is still dominated by the first best solution. This needs further explanation.

For negative correlation, it appears that the ex-post critical value is always too low. Hence, the shareholder would like to commit himself to fire the manager in less cases. From (5.23) and (5.25) we know that the only oredible way to achieve this is by means of a higher severance pamment. However, since the option walue is decreasing in the severance payment (see Lemma 5), the shareholder can definitely not attain the first best solution by increasing the severance payment.

We can also show why, under the system of ex-post compensation, the shareholder Carnot promise to fire the manager at the first best critical value for negative correlation. Take the case of correlation -1 from Table 5.1. If the shareholder conld commit to a critical walue of 288 , the expected firing costs would be 2.61 . The severance paymont that is needed to compensate the managen for these expected firing costs is 17 . In other words, if the shareholden could promise the manager to fire him at critical value of 288 , with a severance payment of 17 , the first best solution would be obtained. However, given a. severance payment of 17 , the optimal ex-post critical walue would be 265 . Figure 5 -3 shows that at a critical value of 265 , the expected fing costs would be thigher than the expected severance payment, which violates the participation constraint of the manager.

For positive correlation, it appears that the ex-post critical walue is always too high. Hence, the shareholder would like to fire the manager more often. Again, from (5.23) and (5.25) we know that this can only be achieved by lowering the severance payment. However, this would volate the participation constrain for the manager, since wo bave 


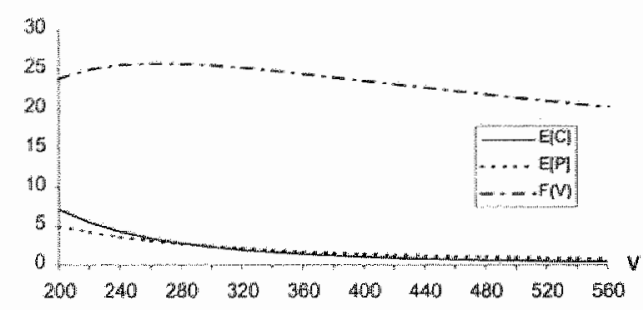

Figure 5-3: Graphical illustration of why the first best hurdle carnot be obtained under the system of ex post compensation, for the following parameter values: $C_{0}=50, V_{0}=$ $100, \mu_{v}=0.04, \sigma_{c}=0.2, \sigma_{v}=0.2, \lambda=0.1, \rho=-1$.

seen in Section 5.6 that the optimal severance payment made the participation constraint for the manager binding.

We can also show why, under the system of ex-post compensation, the shareholder cannot promise to fire the manager at the first best critical value for positive correlation. Take the case of correlation 1 from Table 5.1. Imagine that the shareholder would promise to fire the manager at the first best critical value of 399 . Given that critical value, the expected firing costs would be 9.60 . The severance payment that is needed to compensate the manager for these expected firing costs is 114. In other words, if the shareholder could commit himself to a critical value of 399 , the first best solution could be obtained with a severance payment of 114. However, given a severance payment of 114, the optimal expost critical value would be 480 . Figure 54 shows that at this critical value of 486 , the expected fing costs are again higher than the expected severance payment, which violates the participation constraint.

\subsection{The Second Best}

The question remains whether it is possible to obtain the first best solution by mears of a Ceasible contract. An obvious extension of the systems of ex-ante compensation and ex-post compensation is a combination of the two. In fact, we will show that this combination will always result in the first best solution. 


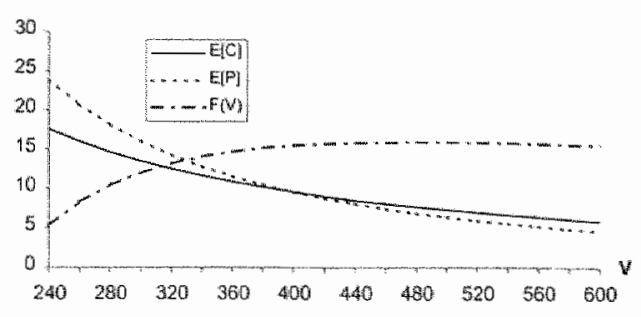

Figure 5-4: Graphical illustration of why the first best hurdle cannot be obtained under the system of ex post compensation, for the following parameter values: $C_{0}=50, V_{0}=$ $100, \mu_{v}=0.04, \sigma_{c}=0.2, \sigma_{v}=0.2, \lambda=0.1, \rho=1$.

We have seen that in the system of ex-ante compensation the shareholder was not able to credibly commit himself to increase the critical value. The result was that the optimal critical value was always higher than the ex-ante critical value. In the system of ex-post. compensation, this critical value was credibly increased by means of the severance payment. However, it appeared that in some cases the optinal critical value was higher than the expost critical value (typically for low correlations), and in some cases the optimal critical value was lower than the ex-post critical value (typically for high correlations).

When the ex-post critical value is too low, the shareholder cannot profitably increase the critical walue by means of a higher severance paynent, bectuse the increased severance payment will simply be too expensive, i.e, the expected sevarance payment will be higher than the expected fring costs. On the other hand, when the ex-post critical value is too high, the shareholder cannot profitably decrease the critical vahe by means of a lower: severance payment, because that will violate the participation constraint for the manager, i.e, the expected severance payment will be lower than the expected fring costs.

However, if the system of ex-post compensation is combined with the systern of ex-ante compensation, any difference betweer the expected severance payment and the expected. firing costs can be settled with a lump sum transfer. In other words, the manager will receive a lump sum payment if the expected firing costs are higher than the expected severance payment, and the manager would pay a lomp sum if the expected fring costs are lower than the expected severance payment. Of cowrse, using Lemma 3 , any difference 
could also be setted by means of a compensation in each period that the manager is still employed instead of a lump sum payment.

The optimization problem of the shareholder now becomes:

$$
\begin{aligned}
& \max _{P L} F(V)_{\text {st }} \\
& \text { S.L. } \\
& E\left[e^{-\lambda T}\right] P+L \geq E\left[e^{-\lambda T} C_{T}\right]_{s b}
\end{aligned}
$$

where st stands for second best.

In. Table 5.2 we compare the mumerical results of the second best problem to those of whe first best problem. We see that the results are similar, as we claimed above.

\begin{tabular}{|r|c|c|c|c|c|c|c|c|c|c|c|}
\hline & \multicolumn{7}{|c|}{ second best } & \multicolumn{4}{c|}{ first best } \\
\hline$\rho$ & $P$ & $V^{*}$ & $E[C]$ & $E[P]$ & $L$ & $F(V)$ & net & $V^{*}$ & $E[C]$ & $F(V)$ & net \\
\hline-1.0 & 27.1 & 288 & 2.6 & 4.1 & -1.5 & 24.2 & 25.7 & 288 & 2.6 & 28.3 & 25.7 \\
-0.5 & 37.7 & 312 & 3.9 & 4.9 & -1.0 & 22.7 & 23.7 & 31.2 & 3.9 & 27.6 & 23.7 \\
0.0 & 50.0 & 340 & 5.6 & 5.6 & 0.0 & 21.2 & 21.2 & 340 & 5.6 & 26.8 & 21.2 \\
0.5 & 63.3 & 370 & 7.5 & 6.1 & 1.4 & 19.8 & 18.4 & 370 & 7.5 & 25.9 & 18.4 \\
1.0 & 76.2 & 399 & 9.6 & 6.4 & 3.2 & 18.7 & 15.5 & 399 & 9.6 & 25.1 & 15.5 \\
\hline
\end{tabular}

Table 5.2: Numerical results for the second best and first best solution, for the following parameter values: $C_{0}=50, V_{0}=100, \mu_{v}=0.04, \sigma_{c}=0.2, \sigma_{v}=0.2, \lambda=0.1$.

Although this contract perfectly imitates the first best solution, it has one obvious drawbick. That is, in practice we do not obserwe that managers pay a lump sum amount (or accept a lower salary) in order to receive a higher severance payment. Hence, for practical purposes it may be more realistic to impose that the lump sum transfer be positive. This is done in Table 5.3

Prom Table 5.3 we observe that only for low (negative) correlations the shareholder still has a commitment problem, i.e., the second best critical value is lower than the first: best ortical value. The reason for this is straightforward. Low (negative) correlations correspond to relatively low expected fring costs. It is in those situations that the shareholder does not want to credibly commit himself to a higher critical value by means of a higher severmone payment, because it is simply too expensive relatively to the expected. fing costs. 


\begin{tabular}{|c|c|c|c|c|c|c|c|c|c|c|c|}
\hline$\rho$ & $P$ & $V^{*}$ & $E[C]$ & $E[P]$ & $L$ & $F(V)$ & net & $V^{*}$ & $E[C]$ & $F(V)$ & net \\
\hline-1.0 & 18.6 & 269 & 3.2 & 4.1 & 0.0 & 25.6 & 25.6 & 288 & 2.6 & 28.3 & 25.7 \\
-0.5 & 30.9 & 296 & 4.4 & 4.9 & 0.0 & 23.6 & 23.6 & 312 & 3.9 & 27.6 & 23.7 \\
0.0 & 50.0 & 340 & 5.6 & 5.6 & 0.0 & 21.2 & 21.2 & 340 & 5.6 & 26.8 & 21.2 \\
0.5 & 63.3 & 370 & 7.5 & 6.1 & 1.4 & 19.8 & 18.4 & 370 & 7.5 & 25.9 & 18.4 \\
1.0 & 76.2 & 399 & 9.6 & 6.4 & 3.2 & 18.7 & 15.5 & 399 & 9.6 & 25.1 & 15.5 \\
\hline
\end{tabular}

Table 5.3: Numerical results for the second best and first best. solution, with a non-negative restriction on $L$, for the following parameter values: $C_{0}=50, V_{0}=100, \mu,=0.04, \sigma_{c}=0.2$, $\sigma_{v}=0.2, \lambda=0.1$.

\subsection{Concluding Remarks}

We have seen that the severance payment is an important means to credibly promise to the manager not to fire him too often. Moreover, there is a positive relation between the correlation between the profit capacity of the potential manager and the firing costs of the incumbent manager on the one hand, and the size of the severance payment on the other hand. This gives us the testable lrypothesis that we can expect relatiwely large severance payments to exist in industries where skills of managers easily become obsolete, $\mathrm{eg}_{\text {. }}$ in industries with rapidly changing technologies, like the information technology sector. On the other hand, we can expect relatively low severance payment to exist in industries where managers frequently rotate to other firms, for example because of changing management styles, like in the consumer goods industry.

\section{Appendix}

\section{Proof of Lemma 1}

Since $C_{T}$ and $V_{T}$ are wo comelated geometric Brownian motions, $\ln \left(C_{T}\right)$ and $\ln \left(V_{r}\right)$ are bivariate normal;

$$
\left[\begin{array}{l}
\ln \left(C_{T}\right) \\
\ln \left(V_{\gamma}\right)
\end{array}\right] \sim N\left[\left(\begin{array}{c}
\ln \left(C_{0}\right)-\frac{1}{2} \sigma_{c}^{2} T \\
\ln \left(V_{0}\right)+\left(\sigma_{v}\right) T
\end{array}\right),\left(\begin{array}{cc}
\sigma_{c}^{2} T & \rho \sigma_{c} \sigma_{\gamma} T \\
\rho \sigma_{v} \sigma_{j} T & \sigma_{v}^{2} T
\end{array}\right)\right]
$$

Futhermore, the conditional distribution $\ln \left(C_{T}\right) \mid \ln \left(V_{T}\right)$ is normal with sxpoctation. $\ln \left(C_{0}\right)-\frac{1}{2} \sigma_{t}^{2} T+\rho \frac{\sigma_{G}}{\sigma_{y}}\left(\ln \left(V_{T}\right)-\ln \left(V_{0}\right)-\left(\tilde{\mu}_{v}\right) T\right)$ and variance $\sigma_{c}^{2}\left(1-\rho^{2}\right) T$. 
Developing (5.12), we have:

$$
\begin{aligned}
E\left[e^{-\lambda T} C_{T}\right] & =E_{T}\left[E\left[e^{-\lambda T} C_{T} \mid V_{T}\right]\right] \\
& =E_{T}\left[e^{-\lambda T} E\left[C_{T} \mid V_{T}\right]\right] \\
& =E_{T}\left[e^{-\lambda T} E\left[e^{\ln \left(C_{T}\right)} \mid V_{T}\right]\right] \\
& =E_{T}\left[e^{-\lambda T} E\left[e^{\ln \left(C_{T}\right)} \mid \ln V_{T}\right]\right] \\
& =E_{T}\left[e^{-\lambda T} E\left[e^{\ln \left(C_{T}\right) \| \ln V_{T}}\right]\right]
\end{aligned}
$$

The imer expectation in $(5 . A .1)$ can be calculated as:

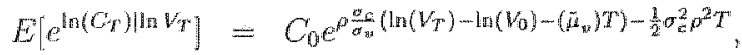

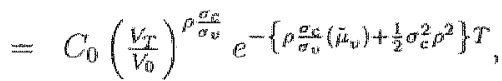

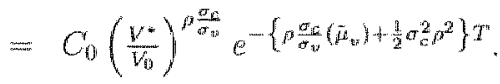

The last step in (5.A.2) follows from the fact that $T$ is the first moment at which $V=V^{*}$. Hence, combining (5.A.1) and (5.A.2), we have:

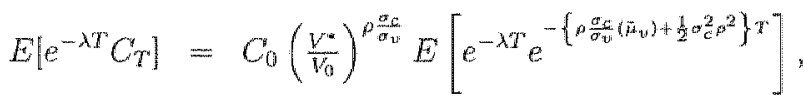

$$
\begin{aligned}
& =C_{0}\left(\frac{V^{*}}{V_{0}}\right)^{e_{\sigma_{u}}} E\left[e^{-\lambda T}\right]
\end{aligned}
$$

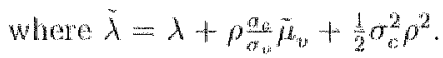

The expectation in (5.A.3) can be calculated as Je.g. Harrison (1985)]

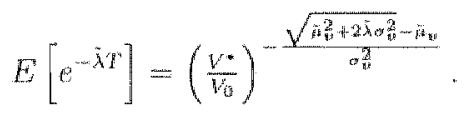

Hence, conbining (5.A.3) and (5.A.4), the expected firing costs are:

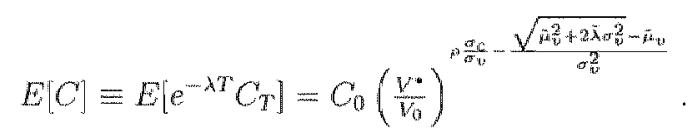

which is equal to equation (5.13) in the text. 


\section{Bibliography}

AGharya, Sankarshan (1992), Maximizing the Market Value of a Firm to Choose Dynamic Policies for Managerial Hiring, Compensation, Firing and Tenuring, International Economic Review, 33(2), 373-397.

Akerlof, George A. (1970), The Market for 'Lemons': Quality Uncertanty and the Market Mechanism, Quarterly Joumal of Economics, 84(3), 488-500.

Albert, Mrafel (1991), Capitalism against Capitalism (in French), Editions du Seuil, Paris.

Baron, D. And D. Besanko (1984), Regulation, Asymmetric Information and Auditing, Rand Journal of Economics, 15, 447-470.

Bentolila, Samuel and Guoseppe Bertola (1990), Firing Costs and Labour Demand: How Bad is Eurosclerosis?, Review of Economic Studies, 57, 381-402.

Berle, Adolph A. and Gaibiner. C. Means (1932), The Modery Comporation and Private Property, MacMillan, New York.

Bertola, Guseppe (1990), Job Security, Employment and Wages, European Economic Review, 34-II(4), 851-886.

Bhatracharya, Sudpto (1979), Imperfect Information, Dividend Policy, matl "The Bird in the Hand' Fallacy, Bell Journal of Economics, 10, 259-270.

Bhrde, Aman (1993), The Hidden Costs of Stock Market Liquidity, Joumal of Financial Economics, 34, 31-51.

Boot, Arnovd W.A. (1994), The Financing of Business Activity: between the Structururegime' and the Financial Sector (in Dutch), Amsterdam University Press, Amsterdam. 
BRANDER, JAMES A. AND TRACY R. LEWIS (1986), Oligopoly and Findncial Structure: The Limitod Liability Effoct, American Economic Revew, 76(5), 956-970.

BYRD, JOHN W. AND KENT A. HICKM (1992a), Do Outside Directors Monitor Managers?, Jourrech of Financial Economics, 32, 195-221.

BYrD, JOHN W. AND KENT A. HICKMAN (1992b), The Case for Independent Outside Directors, Jowrial of Applied Corporate Finance, 5(3), 78-82.

CrAmkHAM, J. (1994), Keping Good Company; A Study of Comporate Govemance in Five Countries, Clarendon Press, Oxford.

CIO, IN-Koo AND David Kneps (1987), Signaling Games and Stable Equilibria, Quarterly Joumal of Economics, 102(2), 179-221.

Cons:, Ronalo H (1937), The Nature of the Firm, Economica, 4, 386-405.

Commiter on Comporate Governande (1997), Corporate Governance in the Netherlands - Forty Recommendations, Amsterdam Exchanges Association, Amsterdam.

Comyon, Martin, Paul Gregg, and Stephen Machin (1995), Taking Care of Business: Executive Compensation in the United Kingdom, Economic Journal, 105(May), $704-714$.

Cools, KeEs (1993), Capital Structure Choice: Confronting (Meta)theory, Empirical Tests and Exesutive Opmion, PhD thesis, Tilburg University, The Netherlands.

CREMER, JACQus (1995), Am's Length Relationships, Quarterly Journal of Economics, $110(2), 275-295$.

DIA Mond, Priter. A. (1982), Wage Detemmation and Efficiency in Search Equilibrium, Rewew of Ecomomic Studies, $49,217227$.

DIXIT, AVINASH K. AND ROBERT S. PINDYCK (1994), Investment under Uncertatndy, Princeton University Press, Princeton, New Jersey.

DonAlBson, Gordon (1994), The Corporate Restructuring of the 1980s-And Its Import for the 1990s, Journal of Applied Conporate Finance, 6(4), 55-69.

EConomist, ThE (1995a), Executive Pay: Random Numbers, 335(June 3rd-9th), $74-77$. EConomist, The (1995b), Fat Cats and Their Cream, 336(July 22nd-28th), 15. 
FAMA, EUGEne F. (1980), Agency Problems and the Theory of the Firm, Journal of Political Economy, 88(2), 288-307.

Fama, Eugene F. And Michael C. Jensen (1983a), Separation of Ownership and Control, Joumal of Low and Economics, 26(2), 301-325.

Fama, Eugene F. And Michael C. Jensen (1983b), Agency Problems and Residual Claims, Joumal of Law and Economics, 26(2), 327-349.

Franks, Julian R. And Walter N. Torous (1994), A Comparison of Financial Re contracting in Distressed Exchanges and Chapter 11 Reorganizations, Joumal of Financial Economics, 35, 349-370.

Garen, John E. (1994), Executive Compensation and Principal-Agent Theory, Joumal of Political Economy, 102-II, 1175-1199.

Gertnerr, Robert And David SGharfstein (1991), A Theory of Workouts and the Effects of Reorganization Law, Joumal of Finance, 46-II(4), 1189-1222.

Giammarino, Ronald M. (1989), The Resolution of Financial Distress, Rentew of Financial Studies, 2(1), 25-47.

Gribons, Robert (1992), A Primer in Game Theory, Harvester Wheatsheaf, New York.

Grossman, Sanford J. And Olver D. Hant (1980), Takeover Bids, the Free-Rider Problem, and the Theory of the Corporation, Bell Journal of Economics, 11, 4264.

Grossman, Sanford J. And Olnver D. Hart (1983), Ar Analysis of the PrincipalAgrent Problem, Econometrica, 51(1), 7-45.

Grunderst, JoskFy A. (1990), Subordination of American Capital, Journal of Finaneial Economics, 27, 89-114.

Harris, Milton and Arthur Raviv (1990), Capital Structure and the Informational Role of Debt, Journal of Finance, 45-I(2), 321-349.

Harrison, J.M. (1985), Brownian Motion and Stochastic Flow Systems, Wiley, Now York. Hart, OLner (1995), Firms, Contracts, and Financial Structure, Oxford University Press, Oxford. 
HAUGE, ROBERT A. AMD LEMMA W. SENDET (1978), The Insignificance of Bankruptcy Costs to the Theory of Optimal Capital Structure, Jowrwal of Finance, 33-1(2), 383393.

HAUCEN, ROBERT A. AND LEMMA W. SENBET (1988), Bankruptcy and Agency Costs: Their Significance to the Theory of Optimal Capital Structure, Joumal of Financinl and Quarutitative Analysis, $23,27-38$.

HAZE WIKELMAN DE, R.A.E. (1994), Impontance of a New Structumregime for the Institutional and Private Investor (in Dutch), in I.W. Wildenberg and F.J.M. Zwetsloot, (eds.), Tomards a New Balance of Pouner in the Dutch Corporation: About the Ristation Between Shareholders, Directors, Management, and Employees in the Dutch Copporation, Kluwer, Deventer.

HERSI, ARTHU AND FuGENE ReBErs (1996), Stock Repurchases in the Netherlands (in Dutch), Tijdschrift voor Bedrijsadministratie, 1190, 174-180.

HoLmstrom, BENGT (1979), Moral Hazard and Observability, Bell Journal of Economucs, $10(1), 74-91$

Holmsinom, Bengit And PAul R. Mhgnom (1987). Aggregation and Linearity in the Provision of Intertemporal Incentives, Econometrica, 55, 302-328.

Jrasen, Muchat. C. (1986). Agency Coste of Free Cash Flow, Corporate Finance, and Trakwers, American Economb Review (Papers and Procedings), 76, 323-329.

Jansm, Michate C. (1989), Eclipse of the Public Corporation, Horvard Business Review, $(5 e p t .-0 c), 6]-74$

JinsEN, MICHAL C. AND WLLIAM H. MrCKLIMG (1976), Theory of the Firm: Managerial Behavior, Agency Costs and Ownership Strncture, Joumal of Financial Economics, $3,305-360$.

Jensen, Mighel C. and Kevin d. Murphy (1990), Performance Pay and TopManagement Incentives, Joumal of Political Economy, 98-I, 225-264.

JENSEN, MICHAEL C. AND RLChARD S. RuBACK (1983), The Market for Corporate Control: The Empirical Evidence, Joumal of Financial Economics, 11, 5 -50. 
KM, HAN E. (1978), A Mean-Variance Theory of Optimal Capital Structure and Corporate Debt Capacity, Journal of Finance, 33, 45-64.

Kofman, Fred and Jacours Lawarree (1993), Collusion in Hierarchical Agency, Econometrica, 61-I(3), 629-656.

Kofman, Fred And Jacques Lawarree (1996), On the Optimality of Allowing Collusion, Journal of Public Economics, 61, 383-407.

Kraus, Alan and Robert H. Litzenibrger (1973), A State-Preference Model of Optimal Financial Leverage, Journal of Finance, 28-II(4), 911-922.

Leland, Hayne E. And Daylg H. Pyle (1977), Information Asymnetries, Financial Structure, and Financial Intermediation, Joumal of Finence, 32-I(2), 371 388.

Maksmovic, Vouslav (1988), Capital Structure in Repeated Oligopolies, Rand Joumal of Economics, 19(3), 389-407.

Maksmovic, Vouslav and Sherdoan Titman (1991), Financial Policy and Reputation for Product Quality, Review of Financial Studies, 4, 1.75-200.

Manne, Henry G. (1965), Mergers and The Market for Corporate Control, Joumal of Political Economy, 73(2), 110-120.

MCDONAld, R. AND D. Sieglel (1986), The Value of Waiting to Invest, Quarterly Journal of Economics, 101(4), $707-728$.

MuLs, DAvid (1993), Testing for Short Termism in the UK Stock Markel, Ecomomir: Jourral, 103(November), 1379-1396.

Mues, David (1995), Testing for Short Termism in the UK Stock Market: A Reply, Economic Journal, 105 (September), 1224-1227.

Modiglanl, franco no Merton H. Miller (1958), The Cost of Capital, Corporation Finance, and the Theory of Investment, American Economic Revicu, 48(3), $261-297$

Modiglani, Franco and Merton H. Millen (1963), Corporate Income Times and the Cost of Capital: a Correction, American Economic Review, 53-II(3), 4334 443. 
Monfuand, PIETen W. (1989), The Market for Takeovers: Theory, Empirics, and Legislation (in Dutch), Mnandblad voor Accountancy en Bedrifseconomie, 63, 143-161.

Mofrlamd, PtEter W. (1995), Alternative Disciplinary Mechanisms in Different Corporate Systems, Journal of Economic Behawior and Organization, 26, 17-34.

Morck, Randall, Andrei Shlemfer, and Robert W. Vishny (1989), Altemative Mechanisms for Corporate Control, American Economic Review, 79-II, 842-852.

MYERS, STEWATT C. (1977), Determinants of Corporate Borrowing, Journal of Financial Economics, 5, 147-175.

O1, Walter Y. (1962), Labor as a Quasi-Fixed Factor, Journal of Political Economy, $70(6), 538-555$

Peteters, Annfinen (1997), How Hiring and Firing Costs Affect Labour Demand in a Mode' of Uncertainty, Mimeo, Catholic University of Leuven.

Perea y Monsuwe, Andres, Mathiss Jansen, and Hans Peters (1997), Consistency of Assessments in Infinite Signaling Games, Journal of Mathematical Economics, $27,425-449$.

Prahala D, C.K. (1994), Corporate Governance or Corporate Value Added?: Rethinking the Primacy of Shareholder Value, Journal of Applied Corporate Finance, 6(4), 40-50. Rerens, EUGENe (1996), Incentize Compensution and Bankruptcy, LIFE Working Paper, No. 96-40, Maastricht University.

Remers, Eucene (1997), Corporate Governance in the Netherlands: The Structuurregime sund Independent Directors (in Dutch), Bedriffskunde, (4), 28-34.

Rebers, Fugene, Rome, Beersma and Hans Peters (1997), When to fite Bad Monagers: The Role of Collusion Between Management and Board of Directors, CentER Discussion Paper, No. 9769, Tilburg University.

Riemkerk, G. (1984), Insider Truding (in Dutch), De Noamlooze Vennootschap, 62(5), $179-184$

Rinnooy Kan, A.H.G. (1994), Modification 'Structuurregime' not in Order (in Dutch), in I.W. Wildenberg and F.J.M. Zwetsloot, (eds.), Tourds a New Balance of Power 
in the Dutch Carporation - Abowt the Relation Betwexw Shareholders, Dircetors, Management, and Employees the Dutch Comporation, Khwer, Deventen.

ROF, MARK J. (1990), Political and Legal Restraints on Ownership and Control of Public Companies, Joumal of Findncial Economics, 27, 7-41.

Ross, STephen A. (1973), The Economic Theory of Agency: The Principal's Problem, Americon Economic Review (Papers and Procedings), 63(2), 134-139.

Ross, STEPHEN A. (1977), The Determination of Financial Structure: The IncentiveSignalling Approach, Bell Journal of Economics, 8, 23-40.

SATCHELL, S.E. AND D.C. DAMANT (1995), Testing for Short Termism in the UK Stodk Market: A Comment, Economic Jowmol, 105(September), $1218-1223$.

SCOTT JR, JAMES H. (1976), A Theory of Optimal Capital Structure, Bell Jowmal of Economics, 7, 33-54.

ShlatFer, ANDRE AND ROBERT W. VISHNY (1997), A Survey of Corporate Govemance, Joumal of Finance, 52-I(2), 737-783.

SPENCE, MnCHAEL (1973), Job Market Signaling, Quanterly Joumal of Economics, 87(3), $355-374$.

THAKOR, ANJAN V. (1991), Game Theory in Finance, Financial Management, $71-94$.

TrRote, JeAn (1986), Herarchies and Bureancraties; On the Role of Collusion in Orga nizations, Joumal of Law, Economics, and Organizdion, 2(2), 181214.

THROLE, JEAN (1992), Collusion and the Theory of Organizations, in .1. w. Laflont, (ed.), Adwances in Economic Theory (Econometrics Soriety Monograph No. 21), Cambridge University Press, Cambridge, $151-206$.

Trnole, JEAN (1994), Incomplete Contracts: Where Do We Stand?, Mimeo, DDI, University of Toulouse.

Trman, Shendon (1984), The Efect of Capital Structure on a Fimm Liquidation De cision, Joumal of Financial Economics, 13, 137-151.

Wuldenbenc, I.W. (1990), Revolt of the Captal Market (mon Dutch), Academie Service, Schoonhowen. 
WIMUMSON, OHVER E. (1985), The Econonit Irstitutions of Capitalism: Firms, Markets, Relational Contracting, Eree Press, New York. 


\section{Nederlandse Samenvatting}

Dit proefschrift bundelt vier essays (hoofdstukken $24 / \mathrm{m} 5$ ) over Corporate Governance. Een goede vertaling van het begrip 'Corporate Governance' in het Nederlands is niet voohanden, dus we volstaan hier met een omschrijwing. Corporate Governance behelst hot. bestum van de moderne vennootschap, alsmede het toezicht op dit bestur. Onder modenne vennootschap verstaan we in dit proefschrift voomamelijk de grote, beursgenoteorde onderneming. Het besturen van een onderneming dient erop gericht te zijn de ondementingsdoelstellingen te werwezenliken, zodanig dat alle belanghebbenden in de ondeneming tevreden kunnen worden gesteld. Te denken valt aan klanten die goede produkten of diensten willen ontwangen, leveranciers die op tijd betaald willen worden, wenknemers die onder goede voorwatarden aangenaam en uitdagend werk willen verichten, de Staat die

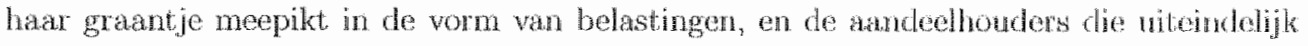
de winst kumen verdelen de resteert nadat aan alle andere verplichimgen is woldan. In dit proefschrift concentreren we ons op drie groepen van belanghebbenden dic exn centrale rol verwullen bij het bestuur van de onderneming on do controle hievop, to witen het management, de Raad van Commissarissen, en de andoelhouders.

Het management wan de ondememing is verantwoordelijk woor het dagelijks bestun] wan de onderneming. en zet de grote lijnen uit. Zij is verantwoording verschuldiggl ande aandeelhouders, voomamelijk wanneer deze Jatste verenigd zijn in de Algemene vergadering van Aandeelhonders. De toezichthoudende taak van de aandeehothders wordt ediber vak in meerdere of mindere mate gedelegeend an een Rad wan Commissarissen, een 
keine groep porsonen met vor het toezicht relevante kemnis of erwaring. Deze delegatie hoft als belangrijk voordeol dat communicatio en coördinatie gemakkeljker tot stand komen binnen een kleine groep van gespecialiseerde personen dan binnen een vaak nogal heterogene aandeehoudersgroep. Een belangrijk nadeel van de delegatie is de noodzaak wan hel nemen var extra maatregelen on ervoor te zorgen dat de Raad van Commissarissen Hadr toewchthoudende taak ook daadwerkelik achequat nitwoert.

In hoofdstuk 2 van dit proefschrift bespreken we een belangrijk alement van het Noderlandse system van Corporate Governance, te weten het Structuurregime. Dit in 1971 ingevoerde systeem betekende een anaienlijke versterking van de positie van de Raad van Commissarissen binmen de moderne wennootschap. Het heeft een aantal belangrijke bevoegdheden, zoals benoeming en ontslag van het management en de goedkeuring van een aantal belangrijke ondernemingsbeslissingen zoals fusies en belangrijke investeringen, wan de Algenene vergadering van Aandedhouders naar de Raad van Commissarissen overgeheveld. Bovendien werd besloten tot een systeem van cooptatie, hetgeen betekent dat de Raad van Commissarissen zelf haar nieuwe leden benoent. In hoofdstuk 2 beargumenteren we dat het Structuurregime als belangrijk voordeel heeft dat de Raad van Commissarissen volledig onafhankelijk wan zowel het management als wan welke belangengroep clan ook haar torachuhoudande tadak kan wervullen, hetgeen ex ante in het belang kan zijn van iedere beInngongroep. Bovendien is het voor het management eenvoudiger om de voor het toezicht trenoligde, wak vertrouwelijke informatio te verschaffen aan een kleine groep personen die voral geselecteend zijn op basis van hun capaciteiten in plaats van hun specifieke belangen.

Wol is hot zo the ererbetering kan komen in de wijze warop de Raad van Commissarissen werantwoording aflegt aan de Agemene vergadering wan Aandeelhouders. Hiertoe dient. nllereerst de rapportage van de Raad van Commissaxissen in het jaarverslag, en aansluitend op de Algenene vergadering van Aandeelhouders, sterk uitgebreid te worden. Op die manier kumen andeelhouders zich en beter beeld women van het functioneren van de Rnad van Commissarissen, kumnen ze een meer zimwolle discussie aangaan in de Algemene 
vergadering van Aandeelhouders, en hebben ze uiteindeligk meer aanknopingspunten voor de rechter indien ze een slecht functionerende commissaris zouden willen ontshasu. Onze mening is dat het Structurregime, met enige aanpassingen, dient, te worden gehandhaafd, hetgeen in overeenstemming is met de relevante passages uit het rapport van de Commissie Peters inzake Corporate Governance.

Een sterke positie voor de Raad van Commissarissen wordt wak belritiseerd uit angst. voor heimelijke samenwerking (collusie) tussen de Raad wan Commissauissen en het managenent, ten koste van de aandeelhouders. Deze collusie is mogelijk omdat aandeehouders niet altijd over de relevante informatie beschikken die nodig is om op de juiste momenten in te grijpen. In hoofdstuk 3 ontwikkelen we een model waarin zulke collusie juist in het belang kan zijn van de aandeelhouders. In dit model delegeert cen aandeelhouder de beslissing om een manager wel of niet te ontslitan aan een commissaris. De manager zal bij ontslag onzekere kosten oplopen, en moet daar clus (ex ante) woor gecompenseerd worden. We bestuderen de optimale beloningsstructuur voor de commissaris, waarbij we rekening houden met de mogelijkheid dat de manager een steekpenning aan de commissaris kan aanbieden om zijn ontslagbeslissing te beïnvloeden. Indien de aandleelhouder collusie verhindert, zal de commissaris een slechte manager altijd ontslaan, zelfs indien de ontslagkosten extreem hoog blijken te zijn. Met andere woorden, zonder collusite zal do commissaris de ontslagkosten op geen enkele wijze internaliseren, en zal de manager dus een hoge vergoeding eisen voor zijn hoge verwachte ontslagkosten. Collusie kan gunstigg zijn voor de aandeelhouder, ondat hij de manager dan niet (ex ante) hoelt te compenseren voor hele hoge realisaties van de ontslagkosten. De reden hiervor is dat precies in dewe gevallen de collusie zal slagen. In de Angelsaksische landen heeft de Raad van Commis sarissen een zwakkere positie dan in de Continentaal-Europese landen. Hocwel dit dus collusie met het management kan bemoeilijken, kan het ook een verklaring bireden woor het feit dat managers een hoger salaris eisen.

Hoofdstuk 4 handelt over adverse selection. Een voorbetd van adwerse selection 
ontstat wamoer managens van een onderneming informatie over de werkelike waarde van hum ondememing hebben (bijworbeeld, goed of slecht) die beleggers niet hebben. Met andere worden, indieri beleggers een (aknded van een) onderneming kopen, lopen wij het risico dwt wij en slechte ondememing kopen. Zolang beleggers geen adnvullende informatie krijgen, zullen zij (de markt) de waarde war een onderneming inschatten als een gewogen geniddelde van de waarde van alle ondernemingen. Ross (1977) heeft een beloningsschena voor de manager ontwikkeld om deze atan te sporen de juiste waarde van ziju ondememing aan de markt te signaleren. In dit hoofdstuk hebben wij het model van Ross geformaliseerd, waarbij we de persoonlike boete van managers afhankelijk hebben gemaakt van de faillissementskosten. Het model werkt als volgt. Managers worden naar rato wan de warde van hun onderneming beloond, en signaleren die waarde met behulp van hur schuldaiveau. Door meer schuld op zich te nemen, krijgen managers te maken met de volgende trade-off. In eenste instantie zullen zij meer verdienen, omdat de markt de waarde van de onderneming hoger zal inschatten als gevolg wan de hogere schuld. In tweede instantie zal hun verwachte beloning echter afnemen, als gevolg van een vergroot risico op Caillissement. We onderzoeken de exacte condities waaronder het competitieve evenwicht van Ross stand houdt. In dit evenwicht zullen managers van goede ondenemingen als zodang lerkend worden, ondat ze en schuldniveau zullen anhouden dat te duur is voor managers van slechte ondermemingen (vanwege de hogere verwachte faillissementskosten). In dit geval zal de adverse selection dus zijn opgeheven.

In hoofdstuk 5 ten slotte ontwikkelen we een model warin een andeelhouder de optiu heft on een manager op ieder gewenst moment te ontslaan. De manager heeft wederom onzekere ontslagkosten op thet moment dat hij wordt ontslagen, en dient daar vor gecompenseerd te worden. Dit kan bereikt worden door de manager een hoger salaris 1. betalen in iedere periode dat hij nog steeds in dienst is, of door hem en ontslagvergoeding (gouden handdruk) te beloven op het moment dat hij daadwerkellik wordt ontslagen. We bestuderen de optimale beloningsstructuur voor de manager, en ook hoe deze zich verhoudt 
met de aard van ontslagkosten. We tonen aan dat met het systeen van een hoger salaris de aandeelhouder de neiging heeft om de manager relatief snel te ontslaan, hetgeen resulteent in hoge verwachte ontslagkosten voor de manager. Aangezien de manager dit anticipeert, zal hij hiervoor ook een hoge vergoeding eisen. Het probleem is dat, als het hogere salaris eenmaal is vastgesteld, de aandeelhouder geen additionele kosten meer heeft bij het ontslaan van zijn manager, ofwel, de ex post marginale kosten van ontslag zijn nihil. Fen belangrijk resultaat van het hoofdstuk is dat dit probleem gedeeltelijk wordt opgelost met het systeem van een ontslagvergoeding achteraf, omdat dit systeem juist wel additionele kosten voor de abandeelhouder impliceert. De implicatie hiervan is dat de ontslagvergoeding een efficient. mechanisme is voor de aandeelhouder on zich te committeren de manager niet te vroeg te ontslaan. De negatieve publiciteit, die de ontslagvergoeding vaak vergezelt dient ons inziens daarom gekwalificeerd te worden. 



\section{Index}

Acharya, 76

Akerlof, 54

Alberti, 47

Baron, $3 \mathbb{1}$

Bentolila, 76

Berle, 3, 12, 13

Bertola, 76

Besanko, 31

Bhattacharya, 54:

Bhide, 19

Boot: 13,16

Brander, 54

Byrd, 14, 16

Charkham, 16

Cho, 55, 56, 65, 67

Coase, 12

Conyon, 30

Cools, 54

Cremer, 76

Damant, 47

De Haze Winkelman, 21

Diamond, 78
Dixit, 80

Domaldson, 22

Fama, 13, 19,38

Branks, 67

Garen, 31, 74

Gertner, 67

Giammarino, 67

Gibbons, 56, 60

Grossman, 20, 31, 74

Grundfest, 16,19

Harris, 56

Harrison, 96

Nant, $20,31,39,74$

Haugen, 67

Herst, 27

Hickman, 14,16

Holmstrom, 31, 74

Jensen, $12,113,19,31,54,56,74$

Kim, 53

Kofman, 31

Kraus, 53 
Kreps, 55, 56,65,67

Lawarré, 31

Inetand, 54

Lewis, 54

Jitzenberger, 53

Maksimovic, 54

Manne, 21, 22

McDonald, 79

Means, 3, 12, 13

Medkling, 12,54

Miles, 47

Milgrom, 31, 74

Miller, 53

Modigliani, 53

Moenland, $13,18,29$

Morck, 14

Murphy, 31.74

Myers, 54

$0 i, 76$

Peeters, 76

Perea y Monsuwe, 60

Pindyck, 80

Prahaliad, 14

Pyle 54
Pebers, in, 27

Rietkerk, 18

Rimnooy Kan, 16, 17

Roes 19

Ross, $7,31,54,63,74$

Ruback, 13

Satchell, 47

Sctuarfstein, 67

Scott, 53

Senbet, 67

Shleifer, 1

Sicgel, 79

Spence, 54

Thakor, 65,66

Tirole, 31,39

Titman, 54

Tonons, 67

Vishry, 1

Wildenberg, 12,13

Williamson, 12

Raviv, 56 


\section{Curriculum Vitae}

Eugene Rebers was born on February 21st, 1969 in Goirle (the Netherlands). He received his Master's degree in Business Administration, specializing in Finance, from the Erasmus University Rotterdam in August 1993. After that, he started his Ph.D at the Finance Department of Maastricht University. From March to May 19g8, he was a visiting student at the Midi-Pyrénées School of Economics in Toulouse, where he completed his Doctoral thesis. As of September 1st, 1998, he has been working at the Ministry of Finance. His main personal interests are chess, cycle racing, and squash.

Eugene Rebers werd geboren op 21 februari 1969, te Goirle. Hij studeerde in augustus 1993 al in de Bedrifseconomie aan de Erasmus Universiteit. Rot terdum, net als spocialsatie Financiering. Daarna trad hij in dienst als Ondewoken-in-Opleidling bij ole Sectir? Financiering van de Unwersiteit Maastricht. Van mant tot mei 1998 verbleef hij als visiting student aan de Mid-Pyrenees Sehool of Econonics in Tonlousa, alwar hij zijn proefschnift voltooicle. Sinds 1 september 1998 werkt hij bij het Ministerie van Financion. Zijn belangrijkste hobby"s zijn schaken, wielrennen an squash. 